\title{
PROPRIEDADES ELETROQUIMICAS E RETENÇÃO ANIÔNICA \\ DE UM LATOSSOLO VERMELHO-ESCURO SOB DIVERSAS PRÁTICAS DE MANEJO
}

\author{
JOSE FLAVIO DYNIA
}

Engenheiro Agronomo

Orientador: Prof. Dr. OTAVIO ANTONIO DE CAMARGO

\begin{abstract}
Tese apresentada Escola Superior de Agricultura "Luiz de Queiroz", da Universidade de Sáo Paulo, para obtençáo do titulo de Doutor em Agronomia. Área de concentraçáo: Solos e Nutrição de Plantas.
\end{abstract}

\author{
$P I R A C I C A B A$ \\ Estado de Sáo Paulo - Brasil \\ Fevereiro - 1993
}


Ficha catalografica oreparada pela Sefáo de Livros da Divisao de Hiblioteca e Documentacta - FCLG/USF

1. Latossolo vermelho-escuro - Brasil (Central) 2. Solo - Propriedade eletroquimica - Alteracăo J. SoloFetenfaco anionica 4. Uso do solo - Efeito I. Escola Superior de Agricultura Luiz de Queirox, Firacicaba

$$
\text { CDD } \quad 631.41
$$




\section{PROPRIEDADES ELETROQUIMICAS E RETENÇÃO ANIÔNICA DE UM LATOSSOLO VERMELHO-ESCURO SOB DIVERSAS PRÁTICAS DE MANEJO}

Aprovado em : 31.03 .93

Comissáo julgadora:

Dr. Otávio Antonio de Camargo IAC-ESALQ/USP

Dr. Toshiaki Kinjo ESALQ/USP

Dr. Jorge de Castro Kiehl ESALQ/USP

Dr. Jose Xavier de Almeida Neto UFG

Dr. Morel Pereira Barbosa Filho 
DEDICATORIA

\author{
A meus pais, Onofre e Eliza (in meworia) \\ Á Olivia, minha segunda mãe \\ Á Suzana, minha esposa,
}

Dedico

A Flavinha, minha luz, 


\section{AGRADECIMENTDS}

Ao Dr. Otávio António de Camargo, que foi muito além da orientação, tornando-se um grande amigo.

A todos os funcionários da Seção de Pedologia do Instituto Agronómico de Campinas, que me ajudaram. Em especial aos Drs. Wanderlei Tremocoldi e José Maria Ayres da Silva Valadares, respectivamente chefe da Seçăo e responsável pelo Laboratório de Quimica do Solo, que muito facilitaram minha atividade nos laboratórios.

Aos colegas Carlos Tadeu dos Santos Dias, João Roberto Ferreira Menk, José Carlos Casagrande, Júlio Cardoso, Luiz Fernando Stone, Orlando Peixoto de Moraes e Amaury Almeida Machado, pela orientaçăo na parte de estatística e computação.

Ao amigo, Dr. José Francisco Valente Moraes, por ceder as amostras de solo do experimento sob sua coordenação.

A EMBRAPA, pela oportunidade oferecida, e ao CNPq, pela bolsa de estudos.

Aos membros da banca examinadora, por se disporem a dedicar parte de seu tempo a leitura e discussão deste trabalho. 


\section{SUMARIO}

Pagina

LISTA DE FIGURAS ......................... vii

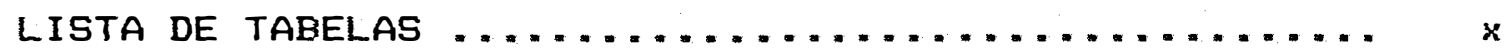

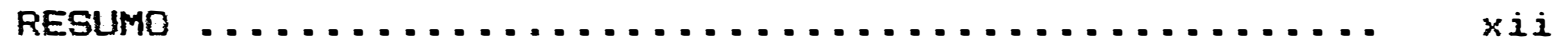

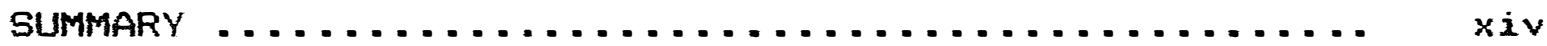

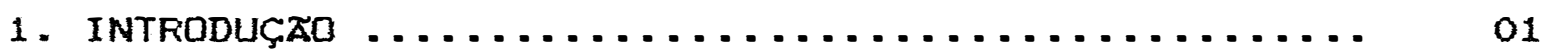

2. REVISÃ DE LITERATURA .....................

2.1. Fropriedades eletroquímicas dos solos de car-

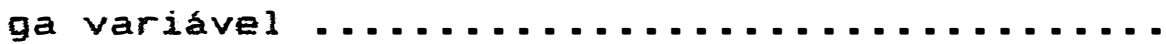

0.3

2.1.1. Efeito da calagem sobre as propriedades eletroquimicas dos solos de carga variável .......................... 06

2.1.2. Efeito da adubação fosfatada sobre as propriedades eletroquimicas dos solos

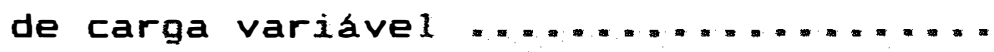

2.1.3. Efeito da materia organica sobre as propriedades eletroquimicas dos solos de carga variável .................

2.2. Adsorção de fósforo em solos de carga variá-

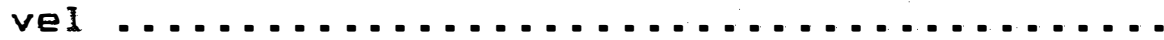

2.2.1. Efeito da calagem sobre a adsorção de

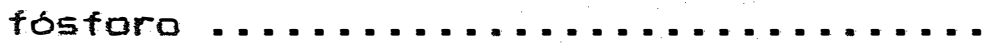

2.2.2. Efeito da adubação fosfatada sobre a

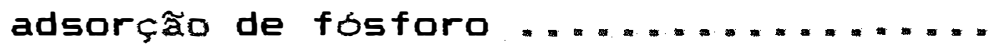

2.2.3. Efeito da materia orgânica sobre a

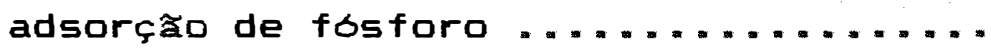


2.3. Adsorção de sulfato em solos de carga variável ..............................

2.3.1. Efeito da calagen sobre a adsorçăo de

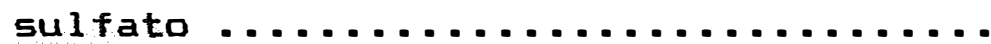

2.3.2. Efeito da adubação fosfatada sobre a

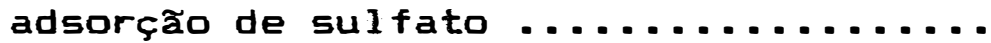

2.3.3. Efeito da matéria orgánica sobre a adsorção de sulfato .............. 24

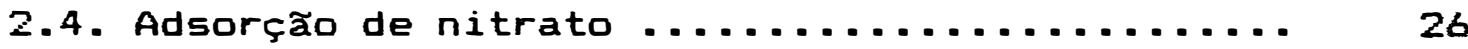

2.4.1. Efeito da calagem sobre a adsorção de

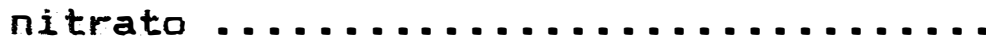

2.4.2. Efeito da adubaçăo fosfatada sobre a adsorção de nitrato ............... 28

2.4.3. Efeito da matéria orgânica sobre a

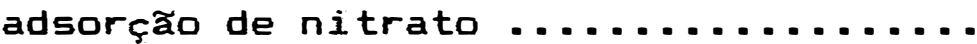

3. MATERIAL E MÉTDDDS ....................... 32

3.1. Solo, tratamentos e amostragem ........... 32

3.2. Análises química e física .............. 35

a) Granulometria .................... 37

b) oxidos livres de ferro e aluminio ........ 37

c) Oxidos amorfos de ferro e aluminio ....... 38

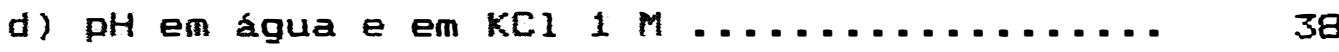

e) Alumínio trocável ........................ 38

f) Cátions trocáveis ................... 39

g) Carbono orgánico .................. 39

h) Fósforo extraivel ......................... 39

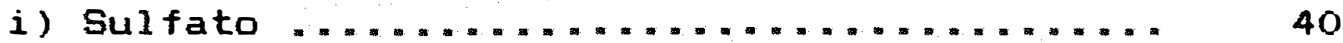

j) Nitrato ..................................... 40

3.3. Caracteristicas eletroquímicas ............ 40

a) Ponto de carga zero (PCZ) e carga eletrica

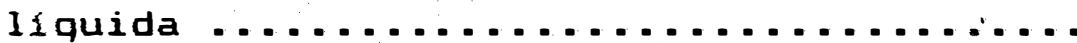

b) Capacidade de troca de cátions e ánions a

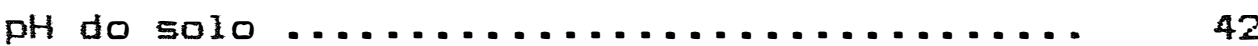

c) Capacidade de troca de cations a $\mathrm{pH} 7,0 \ldots 43$ 
3.4. Adsorção aniónica .................... 43

a) Adsorção de fósforo ................. 43

b) Adsorção de sulfato ................... 45

c) Adsorçăo de nitrato ...................... 46

3.5. Comparaçăo entre os tratamentos ............ 46

4. RESUltaddS E DISCUSSÃ ....................... 48

4.1. Efeito dos tratamentos sobre as propriedades

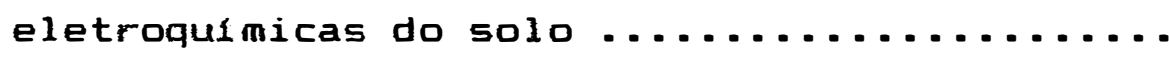

4.1.1. Ponto de carga zero (PCZ) e carga eletrica liquida ...................

4.1.2. Capacidade de troca de cátions (CTC) e de ânions (CTA) .................. 60

4.2. Efeito dos tratamentos sobre a capacidade de adsorção de fósforo, sulfato e nitrato ....... 65

4.2 .1$. Adsorção de fósforo $\ldots . \ldots \ldots \ldots . . . . . .65$

4.2.2. Adsorção de sulfato ............... 73

4.2.3. Adsorção de nitrato ............... 84

5. CONCLUSOES ............................ 89

REFERENCIAS BIBLIDGRAFICAS ................. 90

APENDICE ............................... 111 


\section{LISTA DE FIGURAS}

Pagina

1. Curvas de titulação potenciométrica das amostras do latossolo vermelho-escuro na camada de $0-20 \mathrm{~cm}$. $(T=$ testemunha; $P=$ fósforo; $P A V=$ fósforo + adubo verde; $\mathrm{PCa}$ = fósforo + calcário; $\mathrm{PCaAv}=$ fósforo

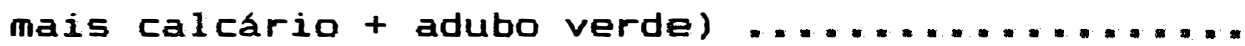

2. Curvas de titulação potenciometrica das amostras do latossolo vermelho-escuro na camada de $20-40 \mathrm{~cm}$. $1 T=$ testemunha; $P=$ fósforo; $P A v=$ fósforo + adubo verde; $\mathrm{PCa}=$ fósforo + calcário; $\mathrm{PCaAv}=$ fósforo

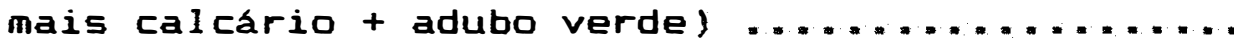

3. Curvas de titulação potenciometrica das amostras do latossolo vermel ho-escuro na camada de 40-60 cm. $(T=$ testemunha; $P=$ fósforo; $P A V=$ fósforo + adubo verde; $\mathrm{PCa}=$ fósforo + calcário; $\mathrm{PCaAv}=$ fósforo mais calcário + adubo verde) ...............

4. Isotermas de adsorção de fósforo do latossolo verme1 ho-escuro nos diversos tratamentos, obtidas através da equação de Freundlich. $\quad(T=$ testemunha; $P=$ fósforo; $\mathrm{PAv}=$ fósforo + adubo verde; $\mathrm{PCa}=$ fósforo + calcário; PCaAv = fósforo mais calcário + adubo verde). O ponto marcado com circulo não foi inclui-

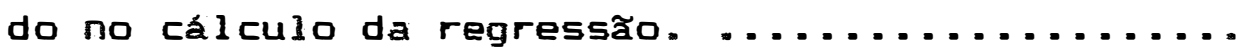


5. Isotermas de adsorção de sulfato do latossolo vermeIho-escuro nos diversos tratamentos na camada de 0-20 cm, obtidas através da equação de Freundlich. $(T=$ testemunha; $P=$ fosforo; $P A V=$ fósforo + adubo verde; $\mathrm{PCa}=$ fósforo + calcário; $\mathrm{PCaAV}=$ fósforo + calcário + adubo verde). Os pontos marcados com circulos não foram incluidos no cálculo das regressões

6. Isotermas de adsorção de sulfato do latossolo vermelho-escuro nos diversos tratamentos na camada de 20-40 cm, obtidas através da equação de Freundlich. $P T=$ testemunha; $P=$ fósforo; $P A V=$ fósforo + adubo verde; $\mathrm{PCa}=$ fósforo + calcário; $\mathrm{PCaAv}=$ fósforo +

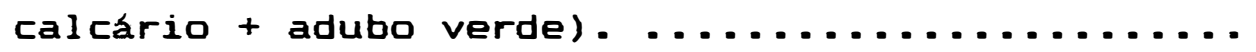

7. Isotermas de adsorção de sulfato do latossolo vermeIho-escuro nos diversos tratamentos na camada de 40-60 cm, obtidas através da equação de Freundlich. ( $T$ = testemunha; $P=$ fosforo; $P A V=$ fosforo + adubo verde; $\mathrm{PCa}=$ fósforo + calcário; $\mathrm{PCaAv}=$ fósforo + calcário + adubo verde). Os pontos marcados com circulos não foram incluidos no cálculo das regressర̃es 


\section{LISTA DE TABELAS}

Página

1. Composição dos tratamentos de campo aplicados ao latossolo vermelho-escuro utilizado no trabalho.

2. Granulometria e teores de óxidos de ferro e alumínio do latossolo vermelho-escuro utilizado no

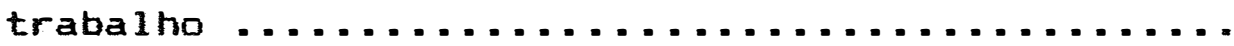

3. Atributos químicos do latossolo vermelho-escuro

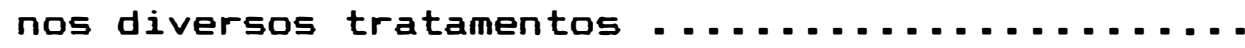

4. Força iônica (I) da soluçăo do latossolo vermelhoescuro nos diferentes tratamentos e camadas -

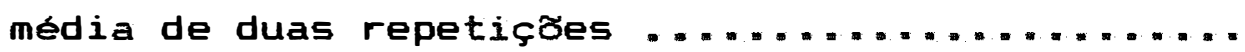

5. Carga elétrica liquida do latossolo vermelhoescuro (meq/100g) nos diversos tratamentos, a tres valores de $\mathrm{pH}$. Os valores foram estimados com base na curva de titulação em KCl 0,001 M ..........

6. Valores de $\Delta \mathrm{pH}$ do latossolo vermelho-escuro nos diversos tratamentos e camadas .............. 
7. Valores de CTC ao pH natural (CTC nat), CTC ao pH 7,0 (CTC 7) a CTA ao pH natural (CTC nat) de um latossolo vermelho-escuro submetido a tratamento com fósforo, calcário e adubo verde ...........

8. Paråmetros das equaçơes de regressão ajustadas ds isotermas de adsorção de fósforo das amostras do latossolo vermelho-escuro, segundo o modelo de Freundlich .............................

9. Variação do potencial eletrico $(\psi \circ)$ dos colóides do latossolo vermelho-escuro nos diversos tratamentos .............................

10. Paråmetros das equaçơes de regressão ajustadas às isotermas de adsorção de sulfato das amostras do latossolo vermelho-escuro, segundo o modelo de Freundlich .............................

11. Capacidade de adsorção de nitrato do latossolo vermelho-escuro em função dos tratamentos médias de duas repetiçठ̃es ................. 
$x i i$

PROPRIEDADES ELETROQUIMICAS E RETENÇAO DE ANIONICA DE UM LATOSSOLO VERMELHO-ESCURO SOB DIVERSAS PRATICAS DE MANEJO

Autor: JOSE FLAVIO DYNIA Orientador: PROF. DR. OTAVIO ANTONIO DE CAMARGO

RESUMO

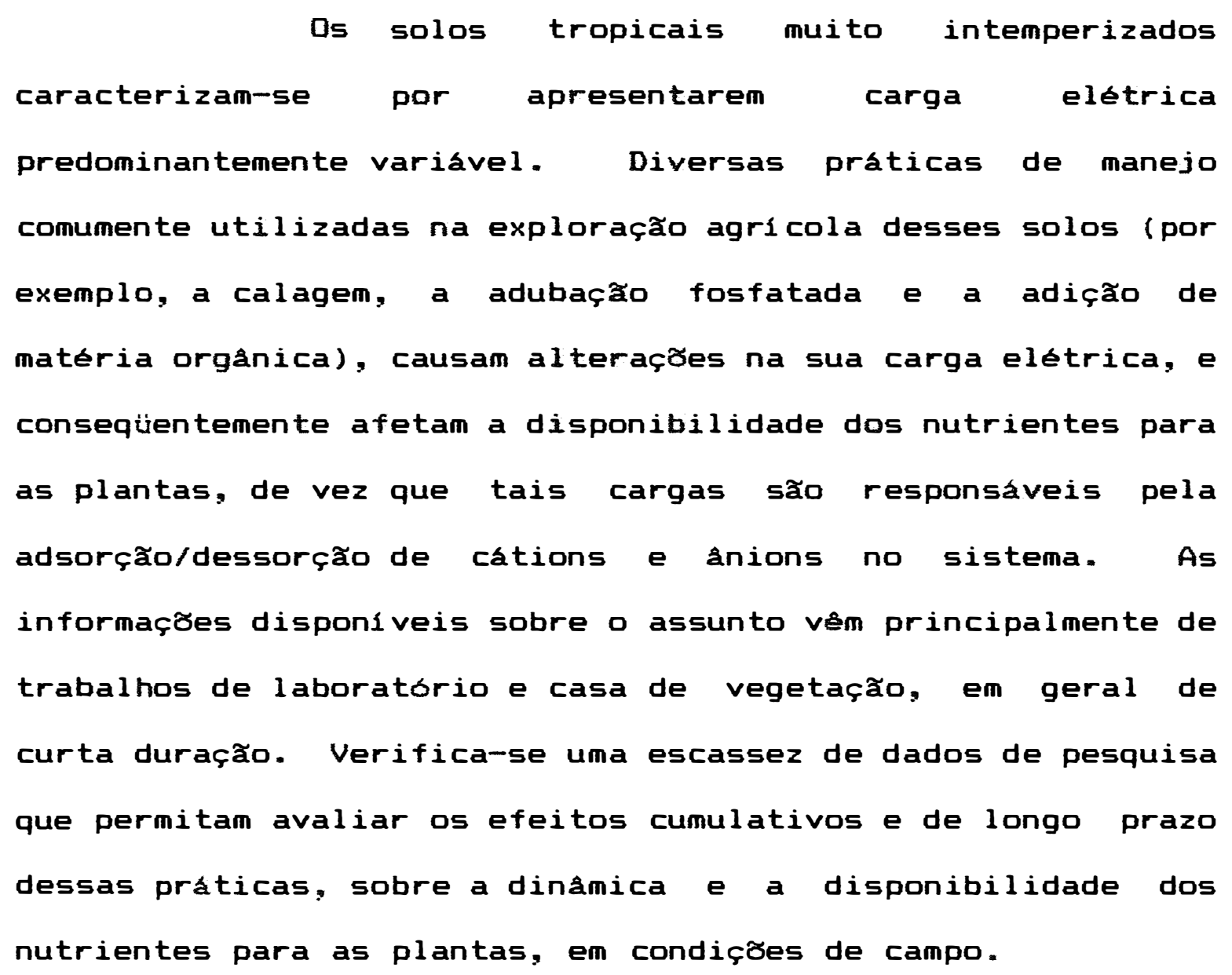


$x i i i$

No presente trabalio, estudaram-se as alteraçớes de algumas caracteristicas eletroquímicas e da capacidade de retençăo de ânions de un solo de carga variável (latossolo vermelho-escuro), causadas por tratamentos com adubo fosfatado, adubo fosfatado + adubo verde, adubo fosfatado + calcário, e adubo fosfatado + calcário + adubo verde. Os tratamentos foram aplicados parceladamente ao longo de seis anos, no solo submetido a dezessete cultivos sucessivos com arroz, feijăo, trigo ou milho. Constatou-se que a adubação fosfatada (334 ppm de $P)$ e a adubação fosfatada + calagem $(5,5$ t/ha realizadas nesse periodo aumentaram a carga liquida $e$ a CTC ao pH natural: e diminuiram a capacidade de adsorção de fosfato, sulfato e nitrato do solo, mas não afetaram o ponto de carga zero (PCZ), a CTC ao pH 7,0 e a capacidade de troca de ánions (CTA) a pH natural. Os tratamentos que associaram a adubação fosfatada e a calagem tiveram efeitos mais acentuados do que a adubação fosfatada, isoladamente. A influência desses tratamentos foi verificada trés anos após a término de sua aplicação, revelando importante efeito residual deles sobre as caracteristicas do solo.

A adubação verde (16 t/ha de matéria seca de guandu), associada à incorporaçăo dos residuos das culturas e na presença de adubação fosfatada ou adubação fosfatada + calagem, não influenciou as propriedades eletroquimicas e a capacidade de retenção de ânions do solo. 
ELETROCHEMICAL PROPERTIES AND ANIONIC RETENTION OF A DARK-RED LATOSOL UNDER SEVERAL MANAGEMENT CONDITIONS

Author: JOSE FLAVIO DYNIA

Adviser: PROF. DR. OTÁVIO ANTONIO DE CAMARGO

SUMMARY

$$
\text { Highly weathered tropical soils are }
$$

characterized by having a predominantly variable charge. Many management practices commonly used in the exploitation of these soils (e.g., liming, phosphate application and manuring) are known to modify their electrical charge and the sorption/dessorption of cations and anions, as this process is partially governed by the charges existing in the soil system. Available information on this subject comes mainly from short-term laboratory and greenhouse experiments. These is a scarcity of data regarding to the cumulative and long-term effects of those practices used at farm-scale levels, on the dynamics and availability of nutrients to the plants, under field conditions.

In the present work, changes in some eletrochemical properties and in the anion sorption capacity of a variable charge soil (dark-red latosol) were studied, as 
influenced by treatments with phosphate, phosphate + green manure (Cajanus cajan), phosphate + lime, and phosphate + lime + green manure, applied during a six years period. In this period rice, bean, wheat or corn, were grown in seventeen successive crops. Phosphate (total 334 ppm P) and phosphate + lime (total 5,5 t/ha) were shown to increase net electric charge and CEC at soil natural $\mathrm{pH}$, to decrease the phosphate, sulfate and nitrate adsorption capacity, and not to affect zero point of charge (ZPC), CEC at $\mathrm{pH} 7.0$, or anion exchange capacity ( $A E C$ ) of the soil at its natural $\mathrm{pH}$. The effects of phosphate +1 ime were more pronounced than that of phosphate alone. Green manure (total $16 \mathrm{t} / \mathrm{ha}$, dry matter), in association with culture residues and phosphate or phosphate + lime, did not influence eletrochemical properties or the anion sorption capacity of the soil. 


\section{INTRODUCCAO}

A fração argila dos solos tropicais altamente intemperizados é constituida predominantemente de caulinita e óxidos de ferro e aluminio, minerais que lhes conferem caracteristica de apresentarem carga eletrica variável. Alteraçชes no $\mathrm{pH}$, na adsorção especifica de anions, na proporção e quantidade de cátions trocáveis e na matéria orgânica modificam a distribuiçăo das cargas eletricas, e, por consequiencia, as propriedades eletroquímicas desses solos.

Em sua maioria, os trabalhos relacionados aos efeitos da variação do pH, da adsorção especifica de ânions e da matéria orgånica sobre as propriedades eletroquímicas dos solos tropicais foram realizados em laboratório ou casa de vegetação, em experimentos de curta duração. Ds resultados indicam que tratamentos com calcário, fósforo e matéria organica alteram as propriedades eletroquimicas e o equillbrio de nutrientes nesses solos. Partindo da hipótese de que esses tratamentos causam as mesmas alteraçôes quando aplicados a campo, procurou-se avaliar seus efeitos, sob condiçôes de lavoura, nas propriedades eletroquímicas e na 
capacidade de retenção aniónica de um solo de carga variável da regiå do Brasil Central. 


\section{REVISAO DE LITERATURA}

\subsection{Propriedades eletroquimicas dos solos de carga variável}

A maior parte das reaçoes que controlam a disponibilidade dos nutrientes para as plantas depende de fenômenos físico-químicos que ocorrem na interface sólido-solução do solo. A fraçăo coloidal constitui a parte ativa do solo, sendo a principal responsável pelos processos de troca iónica que ocorrem entre a fase sólida e a soluçăo. A adsorção e a dessorção de 1 ons pela fase sólida dependem, entre outras coisas, das cargas eletricas existentes na fração coloidal do solo.

As cargas eletricas no material mineral originam-se das substituiçశes isomórficas entre lons de mesmo número de coordenação e de valências diferentes, no interior dos cristais, ou da adsorção de lons determinantes de potencial eletrico, caso especifico do $\mathrm{H}^{+}$e do $\mathrm{oH}^{-}$em solo. No caso de substituiçơes isomórficas, a carga eletrica é permanente, e seu sinal é geralmente negativo. No segundo caso, a carga é variável, e pode ser negativa, positiva ou nula, dependendo da carga e da concentração dos lons 
determinantes de potencial (UEHARA \& GILLMAN, 1980).

Solos tropicais altamente intemperizados, como os da ordem Oxisol, apresentam carga elétrica variável devido a predomináncia, na sua fraçăo coloidal, de óxidos e hidróxidos de ferro e aluminio (RAIJ \& PEECH, 1972; GILLMAN \& BELL, 1976; MORAIs et al., 1976). Esses minerais tém caráter anfótero e sua carga elétrica de superficie é controlada, predominantemente, pela adsorçă ou dessorçă de $\mathrm{H}^{+}$e $\mathrm{aH}^{-}$, principais lons determinantes de potencial no solo (RAIJ \& PEECH, 1972). Uma caracteristica peculiar desses solos é a coexistencia de cargas elétricas positivas e negativas na superficie dos minerais, em condiçశes naturais. Como a distribuiçăo relativa dessas cargas de sinais contrários varia com o pH e com a concentraçăo iơnica da soluçăo do solo (RAIJ \& PEECH, 1972), alteraçớs desises fatores resultam em mudanças na capacidade de retenção de cátions (CTC) e ânions (CTA) pelo solo.

Um importante parametro usado para descrever o comportamento eletroquímico dos solos de carga variável é o seu ponto de carga zero (PCZ). 0 PCZ é definido (RAIJ \& PEECH, 1972) como o pH da solução em equilibrio com o solo, no qual a soma algébrica das cargas elétricas na superfície dos colóides é nula. Guando a pH do solo está acima do PCZ, as cargas negativas predominam sobre as positivas, resultando uma carga liquida negativa para o sistema. Ao contrário, em valores de $\mathrm{pH}$ abaixo do PCZ, predominam as cargas positivas, 
e a carga liquida é positiva.

Assim, a posição do pH do solo em relação ao PCZ fornece indicaçơes sobre a distribuiçăo relativa de suas cargas eletricas. Essa informaçăo pode também ser obtida através do $\Delta \mathrm{pH}$, parâmetro que é definido como a diferença entre o pH do solo em KCl $\mathrm{Ne}$ o pH em água, ou seja, $\Delta \mathrm{pH}=$ $p H(K C 1 N)$ - pH(água) (MEKARU \& UEHARA, 1972). Um $\Delta p H$ positivo indica que o pH do solo está abaixo do PCZ, e o solo apresenta carga liquida positiva (CTA> CTC). Se o $\Delta \mathrm{pH}$ é negativo, o pH está acima do FCZ, e o solo apresenta carga liquida negativa (CTC > CTA) (RAIJ \& PEECH, 1972). Em geral - $\Delta$ pH na camada arável dos solos é negativo. No entanto, isso não implica em total ausência de cargas positivas nessa camada. Um pequeno número de 51 tios com carga positiva pode ocorrer na superficie das particulas, possivelmente em áreas isoladas das cargas negativas e fisicamente distantes destas - suficiente para evitar sua neutralização (SANCHEZ, 1976).

Embora seja uma propriedade relativamente estável dos solos de carga variável, o PCZ é afetado pela adsorção especifica de ånions (UEHARA \& KENG, 1975) e pelo teor de matéria orgânica do solo (RAIJ \& PEECH, 1972; MORAIS et al., 1976). 


\subsubsection{Efeito da calagen sobre as propriedades eletroquimicas dos solos de carga variavel}

- potencial produtivo dos solos tropicais de carga variável é limitado, entre outros fatores, por sua elevada acidez, a qual se reflete, geralmente, na presença de aluminio trocável em níveis tóxicos as plantas. A calagem é a prática mais recomendada para eliminar tal limitação.

Em seu estudo sobre as propriedades eletroquímicas de alguns oxissolos e alfissolos do estado de São Faulo, RAIJ \& PEECH (1972) demonstraram a dependência da distribuição das cargas elétricas na superficie dos colóides desses solos de carga variável em relação ao pH. Os autores observaram que a medida que o $\mathrm{pH}$ do solo aumentava, as cargas negativas aumentavam, e as cargas positivas diminuiam. Como conseqüência, aumentava a carga liquida negativa. 0 mesmo tipo de comportamento foi observado por MoRAIs et al. (1976) em oxissolos, alfissolos e ultissolos da Amazónia e do estado da Bahia. Qutros autores, trabalhando com diferentes solos ácidos de carga variável também constataram aumentos de carga liquida negativa do solo, com o aumento do pH causado pela calagem (SMYTH \& SANCHES, 1983; HAYNES, 1983; BOLAN et al., 1988; NAIDU et al., 1990).

Os resultados de alguns dos trabalhos acima citados (RAIJ \& PEECH, 1972; MORAIS et al., 1976; NAIDU et al., 1990) indicam que o aumento das cargas negativas $e$ a redução das cargas positivas devido à elevação do $\mathrm{pH}$ não é 
proporcional. Além disso, embora as cargas positivas diminuam com o aumento do $\mathrm{pH}$, as mesmas não são totalmente neutralizados, e parte delas pode persistir mesmo a valores elevados de pH (MORAIS et al., 1976; NAIDU et al., 1990).

Assim, como se espera em solos de carga variável, o aumento do $\mathrm{pH}$ devido a calagem, além de neutralizar o aluminio trocável, aumenta a carga negativa desses solos, e portanto causa aumentos na sua CTC. Contrariamente, diminui as cargas positivas, e reduz sua capacidade de troca de ánions (CTA).

2.1.2. Efeito da adubaçăo fosfatada sobre as propriedades eletroquimicas dos solos de carga variável

A aplicação de fertilizantes fosfatados é pratica obrigatória nos solos tropicais de carga variavel, devido sua generalizada deficiência em fósforo. A par de sua função como nutriente, o.fosfato aplicado apresenta também o efeito de aumentar a CTC desses solos (MEKARU \& UEHARA, 1972; WANN \& UEHARA, 1978; GILLMAN \& FOX, 1980). Tal efeito origina-se da adsorção especifica do fosfato aos minerais do solo. Nesse tipo de adsorçăo, o ânion desloca hidroxilas e/ou moléculas de água que se encontram coordenadas com ferro ou aluminio da superficie dos sesquioxidos, aumentando a carga negativa dessas superficies. A baixos valores de pH do 
solo, a aumento da CTC produzido pela adsorção do fosfato parece ocorrer, principalmente, pelo deslocamento de moléculas de água. Á medida que o pH se eleva aproximando-se da neutralidade, o aumento da CTC possivelmente ocorre em função do deslocamento de grupos hidroxila por lons fosfato de maior valéncia, como o $\mathrm{HPQ}^{2-}$ (SAWHNEY, 1974).

Embora incrementos consideráveis da CTC possam ser obtidos com a aplicação de fosfato aos solos, as doses necessárias para tal são geralmente antieconómicas, como demonstram as resultados de alguns trabalhos (MEKARU \& UEHARA, 1972; SCHALSCHA et al., 1974b; GILLMAN \& FDX, 1980; SMYTH \& SANCHEZ, 1980). Um exemplo ilustrativo é fornecido pelos resultados de SMYTH \& SANCHEZ (1980) para um latossolo vermelho-escuro de cerrado. Na ausencia de calagem, 540 ppm de fósforo foram necessários para elevar em cerca de $10 \%$ as cargas negativas do solo (de 1,61 para 1,78 meq/100g). Com a calagem, o aumento foi de cerca de $34 \%$ (de 2,14 para 2,86 meq/100g), para a mesma dose de fósforo. 0 maior aumento de cargas no solo com calagem corrobora a observação (SAWHNEY, 1974) de que menores quantidades de fósforo são necessárias para causar igual aumento da CTC em solo com pH alto do que no mesmo solo com pH baixo.

Paralelamente ao aumento da CTC, a adsorção de fosfato provoca decréscimo da CTA, pela redução do número de cargas positivas do solo. Como no caso da CTC, somente doses elevadas de fosfato parecem capazes de promover reduçá 
considerável na quantidade de cargas positivas. Cita-se, novamente, o trabalho de SMYTH \& SANCHEZ (1980) como exemplo. A aplicação de 540 ppm de fósforo reduziu a CTA do solo de $0,33 \mathrm{meq} / 100 \mathrm{~g}$ para $0,06 \mathrm{meq} / 100 \mathrm{~g}$, mas $380 \mathrm{ppm}$ de fósforo causaram apenas uma pequena redução da mesma, de 0,33 para 0,24 meq/100g.

2.1.3. Efeito da matéria orgânica sobre as propriedades eletroquimicas dos solos de carga variável

A matéria orgånica é o principal componente responsável pelo desenvolvimento de cargas negativas nos solos tropicais de carga variável, sendo consenso geral que sua manutenção é de vital importáncia para a CTC desses solos.

Além de contribuir para o aumento da CTC, a matéria orgånica tem influência também sobre o PCZ de tais solos. Em geral, a presença da matéria orgånica tende a deslocar o PCZ para valores mais baixos de pH (RAIJ \& PEECH, 1972). Possivelmente, ânions orgånicos resultantes da decomposição da matéria orgånica são adsorvidos especificamente a superficie dos sesquióxidos presentes nesses solos. A carga liquida resultante da adsorção aumenta a CTC do solo (ou reduz a CTA) sem alterar seu pH. Como resultado, a relação carga-pH modifica-se e o PCZ torna-se 
mais baixo (SANCHEZ, 1976; TATE \& THENG, 1980).

Evidéncias indiretas desse efeito da matéria orgânica são apresentados em alguns trabalhos (RAIJ \& PEECH, 1972; MORAIS et al., 1976), nos quais se verifica que o PCZ de camadas superficiais dos solos (mais ricas em matéria orgånica) é sempre menor do que nas camadas inferiores. Por exemplo, a diferença entre teores de matéria orgânica nos horizontes $A(2,5 \%$ de carbono orgånico) e B $(0,7 \%$ de carbono orgånico) de um oxissolo testado por RAIJ \& PEECH (1972) resultou numa diferença de PCZ de 3,9 para 6,2 verificados, respectivamente, nos horizontes A e B. Essa diferença nos teores de matéria orgånica entre os dois horizontes foi responsável também pela ocorréncia de carga liquida negativa no horizonte $A$, $e$ de carga liquida positiva no horizonte $B$. Uma evidéncia mais direta e consistente da relação entre o PCZ e a matéria orgânica foi demonstrada recentemente por SIQUEIRA et al. (1990). Utilizando amostras de latossolos de diferentes regioses do pais, os autores verificaram a existéncia de correlaçశ̋es negativas significativas entre o PCZ e o teor de matéria orgânica em diversas camadas nos perfis dos solos. No mesmo trabalho, verificou-se que matéria orgânica (sob a forma de residuos culturais e adubos verdes) incorporada anualmente a um dos solos, num período de seis anos, tendeu a reduzir seu PCZ. 


\subsection{Adsorçăo de fósforo en solos de carga variável}

A deficiência de fósforo é um dos principais problemas de fertilidade dos solos tropicais de carga variável. Esses solos têm, em geral, alta capacidade de adsorção de fósforo. A adubação fosfatada, nesses casos, torna-se indispensável para suplantar a capacidade de adsorção e elevar o teor de fósforo na solução a niveis suficientes para manter o desenvolvimento normal das plantas. Nesses solos, óxidos-hidróxidas de ferro e aluminio săo os principais componentes da fraçăo coloidal responsáveis pela fixação do fósforo (PARFITT, 1978). 0 processo envolve um curto periodo de adsorgão do fosfato a superficie dos minerais, seguido de um período de reaçठ̃es lentas em que o 1 on gradualmente removido da solução do solo (MUNNS \& FOX, 1976) até se atingir o equilibrio entre a fase sólida e a solução. Embora em condiçశes especiais possam ocorrer outras formas de fixaçăo, existe atualmente consenso quase generalizado de que o fosfato es adsorvido especificamente à superficie dos minerais do solo, através de reaçס̃es de troca de ligantes (PARFITT, 1978; MOTT, 1981; GOLDBERG \& SPOSITO, 1985). Nesse tipo de reação o ănion fosfato entra em coordenação com os ions ferro e/ou aluminio da superficie dos minerais, formando ligaçơes covalentes muito estáveis. No caso dos oxidos de ferro, pares FeOH e/ou $\mathrm{FeOH}_{2}^{+}$da superficie reagem com o fosfato da soluçăo formando 
um complexo do tipo FeOP(O2)OFe (PARFITT et al., 1975; PARFITT, 1977). Reação semel hante ocorre com os minerais com octaedro de aluminio na sua estrutura (gibsita e caulinita). Nestes, o fosfato se liga a grupos $\mathrm{Al}(\mathrm{OH}) \mathrm{H}_{2} \mathrm{O}$ da superfície da gibsita e das arestas quebradas de caulinita (MULJADI et al., 1966; PARFITT, 1977; PARFITT et al., 1977), resultando na formação de complexo do tipo AlOP(O2)QAl (PARFITT, 1977), semelhante na estrutura aquele formado na reaçăo com os óxidos de ferro.

A alta capacidade de fixação de fósforo dos solos ácidos ricos em óxidos-hidróxidos de ferro $e$ de aluminio resulta em baixa solubilidade do elemento. No entanto, algumas praticas de manejo comumente utilizadas na exploração desses solos alteram a distribuição relativa das cargas eletricas, ou geram efeitos de competiçăo iónica que podem afetar a adsorção do fósforo, com reflexos na sua disponibilidade para as plantas. Alguns desses aspectos são discutidos a seguir.

2.2.1. Efeito da calagem sobre a adsorçăo de fósforo

A par de seu efeito corretivo da acidez, a calagem afeta a solubilidade do fósforo nos solos ácidos tropicais. SANCHEZ \& UEHARA (1980) consideram que um dos principais efeitos esperados da calagem é o aumento da disponibilidade de fósforo para as plantas. No entanto, como 
indicam os resultados contraditorios da literatura, os efeitos da calagem podem ser muito variáveis. Entre outros exemplos, citam-se os trabalhos de AMARASIRI \& OLSEN (1973), NAIDU et al. (1990b) e REEVE \& SUMNER (1970) que mostraram aumento, diminuição e auséncia de efeito da calagem sobre a adsorção de fósforo em solos ácidos.

A carga elétrica na superficie dos minerais anfoteros dos solos é dependente do $\mathrm{pH}_{3}$ e se torna progressivamente mais negativa à medida que aumenta o pH da solução (RAIJ \& PEECH, 1972). O conseqüente aumento da repulsão eletrostática de ânions deve contribuir para a redução da adsorção do fosfato (SMYTH \& SANCHEZ, 1980), ou para reduzir a força de adsorção do mesmo aos coloides do solo (BOWDEN et al., 1980). Outra hipótese não excludente da anterior, sustentada por alguns pesquisadores (MULJADI et al., 1966; PARFITT, 1977) é a de que o aumento do pH do solo provocado pela calagem resulta em aumento da competição entre os lons hidroxila e fosfato pelos mesmos sitios de adsorção especifica na superficie dos minerais. $\bar{A}$ luz dessas hipóteses, deve-se esperar que a calagem reduza a adsorção de fósforo nos solos ácidos com carga variável.

Os resultados contraditórios encontrados na literatura parecem estar relacionados com as diferentes condiçర̃es experimentais sob as quais a adsorção é avaliada. Variações no processo de incubação dos solos com a calcário e - fosfato são a principal causa para as divergências 
observadas. Entre outros aspectos experimentais, a secagem do solo após a incubaçăo com calcário e antes da aplicação do fosfato modifica de maneira significativa os resultados (HAYNES, 1982).

Nos casos en que a adsorção de fosfato é aumentada pela calagem, a precipitaçăo do aluminio trocável, sob a forma de $A l(O H) 3$, resulta na formação de novas superficies altamente reativas na adsorção de fosfato (HAYNES, 1982). Quando o solo é submetido à secagem após a calagem e com o passar do tempo, os polimeros de hidroxi-aluminio amorfos resultantes da neutralização do alumínio trocável tendem a se cristalizar. No estado amorfo, os polimeros apresentam capacidade de adsorção de fosfato quatro a cinco vezes maior do que quantidade equivalente de Al(OH)s na forma de gibsita (KWONG \& HUANG, 1978). Essa parece ser a razão porque os solos ácidos em geral adsorvem mais fosfato logo após a calagem, quando não sofrem secamento.

Mesmo na auséncia de secamento, o aumento do tempo de contato entre o calcário e o solo propiciaria a cristalização dos polimeros de hidroxi-aluminio formados (HAYNES, 1982), reduzindo a capacidade de adsorção de fósforo. Fortanto, solos que tanham recebido calagem provavelmente terăo sua capacidade de retençăo de fosfato diminuida com o passar do tempo (VOLKWEISS, 1973), embora a curto prazo possa ocorrer redução na disponibilidade de 
fósforo.

\subsubsection{Efeito da adubaçăo fosfatada sobre a adsorçăo de fósforo}

YOUNGE \& PLUCKNETT (1966) desenvolveram o conceito segundo o qual adubaçóes fosfatadas tenderiam a reduzir a alta capacidade de fixação de fósforo de solos ácidos tropicais. Efetivamente, trabalho de BARROW (1974) com diversos solos da Austrália los quais tinham sido incubados com fosfato por doze meses em laboratório, ou haviam recebido adubaçð̋es fosfatadas no campo três anos antes), demonstrou que a adição prévia de fosfato reduziu a capacidade de adsorção deste ânion pelos solos. As curvas de adsorção foram deslocadas e suas declividades diminuiram, indicando redução no poder tampão de fósforo. Segundo aquele autor, parte do fosfato adicionado havia se convertido em formas que bloquearam os sitios de adsorção, tornado-os inativos para novas reaçชes e reduzindo, assim, o poder tampão de fósforo do solo. As doses do elemento utilizadas nesse trabalio foram altas $(500-1500 \mu g$ P/g nos solos incubados em laboratório e 100 - $200 \mathrm{~kg}$ P/ha nos solos no campo). Considerando-se as quantidades de fósforo utilizadas nas propriedades agricolas (geralmente bem menores que as usadas no experimentol, os efeitos das adubaçర̃es fosfatadas devem ser pequenos, podendo-se supor em tais condiçశ̋es que o 
poder tampão de fósforo dos solos permaneça praticamente constante por vários anos (BARROW, 1974). No entanto, a falta de informaçชes concretas sobre os efeitos a longo prazo de aplicaçơes seqüenciais de pequenas quantidades de fosfato levanta a necessidade de investigaçชes sobre o tema.

Além de bloquear os sitios de adsorça especifica na superficie dos colóides, a aplicaçăo de fósforo torna o $\triangle \mathrm{pH}$ mais negativo, diminui o PCZ e aumenta a carga liquida negativa dos solos de carga variável (WANN \& UEHARA, 1978; GILLMAN \& FOX, 1980; SMYTH \& SANCHEZ, 1980; HAYNES, 1983). A repulsão eletrostática de ânions resultante dessas alteraçơes possivelmente tambem contribui para a redução da adsorcão de novas doses de fóforo posteriormente aplicadas ao solo. Indicaçơes nesse sentido são encontradas nos trabalhos de SMYTH \& SANCHEZ (1980) e HAYNES (1983), e corroboram a observação (MULJADI et al., 1966), de que a adsorção de fósforo diminui com o aumento da carga negativa dos solos.

2.2.3. Efeito da materia orgânica sobre a adsorçăo de fósforo

A camada arável dos solos tropicais adsorve, em geral, menos fosfato do que as camadas subsuperficiais, mesmo sendo a perfil homogeneo quanto à textura $e$ à mineralogia. A diferença atribuida ao maior teor de 
matéria orgânica da camada arável, o que contribuiria para reduzir a adsorção (FOX \& KAMPRATH, 1970; MOSHI et al., 1974). Correlaçơes negativas significativas entre os teores de matéria orgânica dos solos e sua capacidade de retenção de fósforo são registradas na literatura (FASSBENDEF, 1969; LEAL \& VELLOSO, 1973; OWUSU-BENNOAH \& ACQUAYE, 1989), embora não reflitam, necessariamente, uma relação direta de causa e efeito (SANCHEZ \& UEHARA, 1980). Não obstante esta ressalva, desde muito tempo admite-se que a matéria orgánica adicionada ao solo contribui para aumentar a disponibilidade de fósforo para as plantas (DALTON et al., 1952). Em alguns trabalhos dessa época, demonstrou-se que diversos ânions orgânicos, comuns nos solos, reduziam a fixaçăo do fósforo (SWENSON et al., 1949; STRUTHERS \& SIELING, 1950; DALTON et al., 1952). Considerava-se que sob certas condiç̋es, diversos ánions orgânicos (tais como citrato, oxalato, tartarato, malato, malonato, galacturonato e outros), formavam complexos estáveis com ferro e aluminio do solo, evitando em parte a fixação do fósforo adicionado, ou mesmo tornando disponivel o fósforo já fixado pelo solo. Essas idéias permanecem válidas ainda hoje embora algumas pesquisas da época (RENNIE \& MCKERCHER, 1958) e outras mais recentes (HARTER, 1969) indiquem que a presença de matéria orgânica aumenta a retenção do fósforo, ou ainda (APPELT et al., 1975), que não a afeta.

A possibilidade de compostos orgánicos 
competirem, efetivamente, com o fosfato pelos sitios de adsorção do material do solo, reduzindo a fixaçăo, é reforçada por resultados de diversos trabalhos recentes (DEB \& DATTA, 1967; NAGARAJAH et al., 1970; LOPEZ-HERNANDEZ et al., 1979; KAFKAFI et al., 1988; EASTERWDOD \& SARTAIN, 1990). Segundo DEB \& DATTA (1967), a efetividade dos ânions orgânicos na redução da fixação do fósforo depende, entre outros fatores, de sua natureza fisico-quimica e das condiçơes do meio, especialmente do pH do solo. Possivelmente esta seja a razăo da discrepância de resultados entre os trabalios que indicam efeitos negativos, em relação aqueles que apontam efeitos positivos da matéria orgânica sobre a disponibilidade do fósforo nos solos.

$$
\text { Apesar de alguns resultados conflitantes, }
$$
significativa parte da literatura sobre o assunto indica que produtos da decomposição de adubos verdes ou residuos de culturas podem aumentar a disponibilidade de fósforo para as plantas em solos com alta capacidade de fixaçăo. Por exemplo, SHARPLEY \& SMITH (1989) constataram redução do teor de P ocluso e aumento da disponibilidade de fósforo em vários solos tratados com residuos culturais de natureza diversa. 0 aumento da disponibilidade de fósforo foi atribuido a um possivel bloqueio e redução do potencial de carga dos sitios de adsorção de fósforo pelos produtos de decomposição dos residuos culturais. Resultados semelhantes foram obtidos por LE MARE et al. (1987), trabalhando com um latossolo de 
cerrado. Eles constataram que embora năo tenham afetado a capacidade de adsorçăo de fósforo do solo, tratamentos com residuos culturais e adubos verdes (incorporados anualmente ao solo ao longo de um periodo de sete anos, em condiçoes de campo) aumentaram a proporfão de fosfato isotopicamente trocável e a concentração de fosfato em solução mantida por determinada quantidade de fosfato adsorvido.

\subsection{Adsorçáo de sulfato em solos de carga variável}

o ânion sulfato é a principal forma mineral do enxofre no solo, em condiçరes aeróbicas, e também a forma preferencialmente absorvida pelas plantas (HARWARD \& REISENAUER, 1966). A disponibilidade e a movimentaçăo do sulfato no solo dependem, entre outros fatores, das reaçðes de adsorção que ocorrem entre o sulfato presente na soluçăo do solo e os minerais da fraçăo argila. A capacidade de adsorção varia de solo para solo em funçăo de suas caracteristicas físico-quimicas particulares. Solos muito intemperizados, ricos em sesquioxidos, adsorvem quantidades expressivas de sulfato (HARWARD \& REISENAUER, 1966: PARTIFF, 1978). No caso de solos tropicais a capacidade de adsorça de sulfato assume grande importancia, tanto sob o aspecto do armazenamento do ânion no perfil (como um meio de reduzir perdas por lixiviação na época chuvosa), como por seus efeitos sobre a disponibilidade de enxofre para as plantas 
(COUTO et al., 1979).

0 mecanismo de ligação do sulfato aos coloides do solo é ainda um tema controvertido. Evidência disso săo os vários modelos que têm sido propostos para explicar as reaçơses desse ânion com os minerais do solo. Os resultados da literatura parecem indicar a existencia de mais de um mecanismo de adsorçăo. Embora se admita a ocorrência de adsorção eletrostática (MOTT, 1981; MARSH et al., 1987; CAMARGO \& RAIJ, 1989), a maior parte dos trabalhos nesta área indica que o sulfato sofre também adsorção especifica, através de reaçós de troca de ligantes entre o $\mathrm{SO}_{4}^{2-}$ da solução e as superficies adsortivas (GEBHARDT \& COLEMAN, 1974 ; PARFITT \& RUSSEL, 1977; PARFITT \& SMART, 1978; RAJAN, 1978, 1979; ZHANG et al., 1987; MARCANO-MARTINEZ \& MCBRIDE, 1989; TURNER \& KRAMER, 1991). O mecanismo envolve a reaçăo do ånion com os lons ferro e/ou aluminio expostos na superficie das particulas do solo (HARWARD \& REISENAUER, 1966), os quais estão coordenados com grupos aquo $\left(\mathrm{OH}_{2}\right)$ ou hidroxilos $\left(\mathrm{OH}^{-}\right)$.

A liberação de $\mathrm{OH}^{-}$para a solução (com conseqüente aumento do $\mathrm{pH}$ ) durante o processo de adsorção do sulfato e o aumento de carga negativa das superficies (HUE et al., 1985; ZHANG et al., 1987), são postulados como fortes evidencias da adsorção especifica do sulfato. No entanto, sabe-se que o sulfato adsorvido menos fortemente que o fosfato (PARFITT \& RUSSEL, 1977) e que o processo de adsorção 
é dependente do pH do meio (BARROW, 1970; COUTO et al., 1979; BOLAN et al., 1986; NODVIN et al., 1986). Alem disso, o sulfato parece não competir efetivamente com o fosfato pelos sitios de adsorção (RYDEN et al., 1987). CURTIN \& SYERS (1990) sugerem que o sulfato sofre uma "adsorção especifica de baixa afinidade", termo cunhado por UEHARA \& GILLMAN (1981) para definir a situação na qual, apesar da forte energia de ligação, o ânion não se torna quimicamente coordenado com os átomos dos metais (Fe e Al) da superficie dos minerais. Em apoio a esta hipótese, alguns pesquisadores (BOLAN \& BARROW, 1984; BARROW, 1985) consideram que a adsorção do sulfato se dá em um plano mais afastado da superficie adsorvente do que o plano de adsorção do fosfato.

Como se observa, a dinámica do sulfato no solo depende das caracteristicas da carga eletrica existente na superficie dos minerais que comprom sua fração coloidal. Nos solos de carga variável, tais caracteristicas são alteradas, entre outros fatores, pela calagem, adubação fosfatada e adição de matéria orgånica.

\subsubsection{Efeito da calagem sobre a adsorçáo de sulfato}

A adsorção de sulfato e altamente dependente do $\mathrm{pH}$ do solo. Diversos trabalhos têm demonstrado que a adsorção diminui com o aumento do $\mathrm{pH}$ da solução (BARROW, 1970; COUTO et al., 1979; BOLAN et al., 1986; NODVIN et al., 
1986; MARSH et al., 1987; GUADALIX \& PARDO, 1990). Assim, como consequência da calagem, o teor de sulfato na solução do solo se eleva (HARWARD \& REISENAUER, 1966; BOLAN et a .., 1988), aumentando sua disponibilidade para as plantas. No entanto, na ausencia de absorção pelas ralzes das plantas, o sulfato liberado para a solução do solo pode ser lixiviado. Alguns trabalhos realizados em laboratório com colunas de solos demonstram claramente que a calagem favorece a lixiviação do sulfato (CHAO et al., 1962; BOLAN et al., 1988).

Em vista das consideraçơses acima deve-se esperar que a calagem, ao lado dos beneficios bem conhecidos, apresente a desvantagem de facilitar a lixiviação do sulfato no perfil do solo. Dependendo da duração e intensidade das chuvas numa dada região, a lixiviaçăo pode ser intensa. No entanto, o sulfato lixiviado da camada arável pode ser retido, pelo menos em parte, nas camadas inferiores do solo. Condiçชes de acidez favoráveis ao desenvolvimento de cargas positivas (CAMARGO \& RAIJ, 1989), e/ou maior capacidade de adsorção de sulfato das camadas subjacentes à camada arável, podem contribuir para manter parte do sulfato lixiviado ainda ao alcance das ralzes de plantas com sistema radicular profundo. Havendo uma camada com tais caracteristicas, a taxa de lixiviação do ânion pode ser reduzida, particularmente se sua concentração na soluçăo do solo é baixa (BLACK \& WARING, 1979). Esta parece ser uma condição 
comum nos solos tropicais de carga variável, como demonstram resultados de JOHNSON et al. (1979) e MORAES (1991).

\subsubsection{Efeito da adubaçáo fosfatada sobre a adsorçáo} de sulfato

Entre os ânions presentes nos solos, o fosfato é, possivelmente, aquele que apresenta maior efeito de competição com o sulfato em termos de adsorção (CHAO, 1964), - que explica a utilização de soluçơes fosfatadas na extração do sulfato "disponivel" em solos. Essa caracteristica do fosfato tem sido comprovada na literatura especifica que, invariavelmente, registra seu efeito depressivo sobre a adsorf̧a de sulfato (CHAO et al., 1962; BORNEMISZA \& LLANOS, 1967; HAYNES, 1983; BOLAN et a 1., 1988; PARDO \& GUADALIX, 1990), facilitando sua lixiviação no solo (CHAO et al., 1962; BOLAN et al., 1988). O efeito do fosfato aplicado ao solo sobre a redução da adsorção de sulfato pode ser atribuido à sua maior força de competição pelos sitios de adsorçăo, ou ao aumento da carga negativa das superficies adsortivas (BOLAN et al., 1988). Como a energia de ligação do fosfato com os átomos de ferro e de alumínio dos minerais é maior que a do sulfato, ocorre o deslocamento deste último para a solução do solo quando se adiciona fosfato (PARDO \& GUADALIX, 1990).

As consideraçơes feitas anteriormente com relação à calagem aplicam-se também no caso da adubação fosfatada. Embora essas duas práticas de manejo aumentem, 
momentaneamente, a disponibilidade de sulfato no solo, tal vantagem pode ser suplantada pelo inconveniente do aumento da sua lixiviação no perfil do solo.

2.3.3. Efeito da matéria orgânica sobre a adsorçăo de sulfato

A camada superficial dos solos adsorve, em geral, pouco sulfato em relação às camadas subsuperficiais (HESSE, 1957; WILLIAMS \& STEINBERGS, 1964; JOHNSON \& HENDERSON, 1979; JOHNSON \& TODD, 1983). Isto se deve, provavelmente, ao maior teor de matéria orgânica na superficie, como parecem indicar os resultados experimentais relatados na literatura. For exemplo, CouTo et al. (1979) verificaram que a capacidade de adsorção de sulfato dos horizontes Ap de alguns solos do Estado de São Paulo era consideravelmente menor que a capacidade de adsorção dos respectivos horizontes B2. Como os dois horizontes tinham praticamente a mesma composição mineralógica, os autores atribuiram a diferença de adsorção à matéria orgânica, cujos teores eram mais altos nos horizontes Ap. A mesma relação foi observada por JOHNSON \& TODD (1983) em outros solos. Comparando as quantidades de sulfato adsorvidas e diversas caracteristicas dos solos, em diferentes profundidades nos perfis, esses pesquisadores concluiram que a capacidade de adsorção do sulfato relacionava-se negativamente com o teor 
de carbono orgånico nos diferentes horizontes.

A matéria orgånica está comumente associada ao recobrimento dos óxidos-hidróxidos de ferro e aluminio do solo: Admite-se que as camadas de matéria orgânica que se depositam sobre esses minerais podem bloquear sitios de adsorção na superfície, reduzindo sua capacidade de adsorver ânions como o sulfato (COUTO et al., 1979; JOHNSON et al., 1979). Por outro lado, um grande número de ánions orgânicos comuns nos solos (oxalato, tartarato e malato, entre outros) apresentam a propriedade de reduzirem a capacidade de adsorção de sulfato pelos solos. A redução da adsorção se dá em grau variável, dependendo do tipo e da concentração relativa de cada ánion e das caracteristicas do solo. Ds efeitos de tais ânions podem ser explicados com base na competição com o sulfato pelos sitios de adsorção e/ou pela sua habilidade em formarem complexos estáveis com ferro e aluminio do solo (CHAD, 1964).

Considerando-se que os ânions orgânicos são resultantes da decomposição microbiana da matéria orgânica nativa ou adicionada, deve-se esperar que a incorporação de material vegetal ao solo modifique sua capacidade de adsorçăo de sulfato. 


\subsection{Adsorção de nitrato}

o anion nitrato é a principal forma mineral de nitrogénio nos solos aeróbicos, e também a forma preferencialmente absorvida pelas plantas. Devido ao fato de ser repelido pelas cargas negativas predominantes nos colóides dos solos e em função de sua alta solubilidade em água, quase todo o nitrato encontra-se na solução do solo e, portanto, sujeito à lixiviação. Nas regiőes temperadas, onde os solos apresentam carga negativa constante, o nitrato movimenta-se livremente no perfil, causando perdas consideráveis de nitrogénio. Por outro lado, nos solos tropicais de carga variável, cargas positivas e negativas coexistem na superficie dos colóides. A ocorrencia de cargas positivas possibilita a adsorção eletrostatica de ânions como o cloreto e o nitrato. Nesse tipo de adsorção não especifica os anions são retidos na camada difusa, atuando como contra-ions que neutralizam as cargas positivas existentes nas particulas minerais.

A adsorção de nitrato em solos de carga variável tem sido constatada por diversos pesquisadores (SINGH \& KANEHIRO, 1969; KINJO \& PRATT, 1971a; BLACK \& WARING, 1976; TONER et al., 1989; WONG et al., 1990). Como conseqúência dessa adsorção, a lixiviação do nitrato no perfil do solo pode ser retardada (RAIJ \& CAMARGO, 1974; WONG et al., 1987, 1990) e quantidades consideráveis do anion 
podem permanecer sob a forma trocável, resultando em melhor aproveitamento do nitrogénio pelas plantas. No entanto, as cargas positivas desses solos săo variáveis. Dependem, entre outros fatores, do $\mathrm{pH}$, da concentraçăo e valência dos contra-ions existentes na solução do solo (RAIJ \& PEECH, 1972). Assim, práticas de manejo que reduzam o número de cargas positivas dos solos reduzirão sua capacidade de adsorçăo de nitrato, favorecendo a lixiviaçăo do ânion.

\subsubsection{Efeito da calagem sobre a adsorçá de nitrato}

Nos solos de carga variável, o aumento do $\mathrm{pH}$ resultante da calagem tem como consequiencia um aumento das cargas negativas e, simultaneamente, uma redução das cargas positivas (SMYTH \& SANCHEZ, 1980; NAIDU et al., 1990a). A redução do número de sitios com carga positiva resulta em diminuição da capacidade do solo para reter ânions que săo adsorvidos eletrostaticamente, como o nitrato, e, portanto, concorre para aumentar sua lixiviaçăo no perfil do solo. Todavia, os efeitos da calagem limitam-se a camada arável do solo onde o calcário é incorporado. Por conseguinte, o nitrato lixiviado dessa camada pode ainda ser adsorvido nas camadas subjacentes. Sabe-se que as camadas subsuperficiais dos solos de carga variável podem apresentar considerável capacidade de adsorçăo de nitrato (KINJO \& PRATT, 1971a; BLACK \& WARING, 1976). Em geral, a capacidade de adsorção 
nessas camadas é maior do que na camada arável, devido ao maior número de cargas positivas e também ao menor teor de matéria orgånica dessas camadas (SCHALSCHA et al., 1974a; BLACK \& WARING, 1976).

\subsubsection{Efeito da adubaçáo fosfatada sobre a adsorçâo de nitrato}

Além de suprirem a deficiencia de fósforo, as adubaçơes fosfatadas aumentam a CTC dos solos de carga variável, principalmente quando o fosfato é aplicado em altas doses (SAWHNEY, 1974; GILLMAN \& FOX, 1980; SMYTH \& SANCHEZ, 1980). O aumento da CTC se dá porque o ânion fosfato, adsorvido especificamente aos minerais de carga variável, baixa o valor do PCZ e aumenta a quantidade de cargas negativas (WANN \& UEHARA, 1978; LAVERDIERE, 1982).

Simultaneamente ao aumento das cargas negativas, a adubação fosfatada reduz as cargas positivas do solo (SMYTH \& SANCHEZ, 1980; NAIDU et al., 1990a). Assim, o efeito corretivo do fosfato, aumentando a CTC, favorece a retenção de cátions, mas ao mesmo tempo desfavorece a retenção de ânions que săo adsorvidos eletrostaticamente aos sitios de carga positiva. Exemplo desse efeito pode ser visto no trabalho de KINJO \& PRATT (1971b). Trabalhando em laboratório com amostras de subsolo de dois andossolos e um oxissolo (esse do Brasil) que apresentavam alta capacidade 
de retenção de nitrato, os autores verificaram que a quantidade de nitrato adsorvido decrescia linearmente a medida que aumentava a adsorção de fosfato pelos solos. As isotermas de adsorção na presença de diferentes concentraçâs de fosfato em solução aproximavam-se de zero quando o fosfato na solução de equilibrio atingia cerca de $0,001 \mathrm{~N}$ em $\mathrm{H}_{2} \mathrm{PO}_{4}^{-}$ (aproximadamente, $30 \mu g / m l$ de $P$ ), passando a ocorrer adsorção negativa (dessorção) acima desse valor. A adsorção negativa é explicada pela exclusão do nitrato da camada difusa, em função da neutralização das cargas positivas pelo fosfato. A neutralização dessas cargas aumenta a repulsão eletrostática de ânions como o nitrato, que tên baixa afinidade de adsorção em comparação com o fosfato.

A alta afinidade das superficies adsortivas pelos lons fosfato permite que eles desloquem lons nitrato já adsorvidos ao solo e neutralizem as cargas positivas, reduzindo ou eliminando a adsorção de nitrato. Desse modo, a retenção de nitrato diminui na camada arável de solos com carga variável adubados com fosfato (KINJO \& PRATT, 1971b). Camadas subjacentes à camada arável seriam responsáveis pela retenção do nitrato no perfil do solo (KINJo \& PRATT, 1971C).

\subsubsection{Efeito da materia orgânica sobre a adsorça de nitrato}

A avaliação dos efeitos diretos da matéria orgánica sobre a adsorção de nitrato pelo solo é dificultada 
pela estreita relaçăo que existe entre a mineralizaçăo da matéria orgånica e a produção desse ånion. No entanto, deve-se esperar que, por efeito de competiçăo pelos sitios de carga positiva, ânions orgânicos resultantes da decomposiçăo da matéria orgânica nativa ou adicionada ao solo reduzam a adsorção de nitrato. Tal efeito já foi constatato em relaçăo a adsorção de fosfato (NAGARAJAH et al., 1970; LOPEZ-HERNANDEZ et al., 1979) e sulfato (CHAO, 1964), ânions que, ao contrário do nitrato, são adsorvidos especificamente e têm, portanto, maior poder de competição pelos sitios de adsorção.

A redução do teor de matéria orgânica no perfildo solo com o aumento da profundidade (causando redução na superfície disponivel para o desenvolvimento de cargas negativas) é um aspecto importante na adsorção de nitrato (BLACK \& WARING, 1976). Estudando a relação entre os teores de matéria orgânica e a adsorção em diversas amostras de solos da Austrália, esses autores verificaram que em níveis de carbono orgånico acima de $0,3 \%$ a adsorção de nitrato decrescia rapidamente com o aumento no teor do elemento, até ao ponto de ocorrer a exclusão do ânion em uma amostra de solo da camada de $0-20 \mathrm{~cm}$, que apresentava $3 \%$ de carbono orgånico. Os autores constataram a ocorrência de adsorção positiva e crescente já a partir de $20 \mathrm{~cm}$ de profundidade. Embora pequena, a adsorção medida na faixa de 20 a $60 \mathrm{~cm}$ de profundidade $\left(0,04\right.$ a 0,17 meq $\mathrm{NOa}^{-} / 100 \mathrm{~g}$ de 
solo) indica que parte do nitrato lixiviado da camada arável pode ser retida em. camadas próximas a superficie, permanecendo potencialmente disponivel para plantas com sistema radicular profundo. 
3. MATERIAL E METODOS

\subsection{Solo, tratamentos e amostragem}

o solo utilizado no trabalho foi um latossolo vermelho-escuro (oxissolo), da Fazenda Capivara, localizada no municipio de Goianira, GO $\left(16^{\circ}\right.$ de latitude sul; $49^{\circ}$ de longitude oeste), e pertencente ao Centro Nacional de Pesquisa de Arroz e Feijão (EMBRAPA/CNPAF).

As amostras do solo foram coletadas em abril de 1991, en parcelas de um experimento de fertilidade realizado entre novembro de 1982 e julho de 1989 . Entre julho de 1989 e a data de coleta das amostras, a área permaneceu em pousio. No periodo novembro/82 - julho/89 foram realizados dezessete cultivos alternados com arroz, feijăo, milho e trigo. O preparo do solo em cada cultivo constou de uma aração, e uma ou duas gradagens. Antes do preparo do solo, os restos da cultura anterior foram ceifados e incorporados em cada parcela, mediante a passagem de uma grade com os discos abertos. A adubação e a semeadura foram feitas em linha. Foi feita irrigação por aspersão, quando necessária. Todos os tratamentos tiveram quatro repetiçŏes, distribuldas em blocos ao acaso, e as parcelas experimentais 
tinham área de $100 \mathrm{~m}^{2}(10 \mathrm{~m} \times 10 \mathrm{~m})$. Dentre diversos tratamentos que compunham o experimento, cinco foram selecionados para o presente trabalho (tabela 1).

Tabela 1 - Composição dos tratamentos de campo aplicados ao latossolos vermel ho-escuro utilizado no trabalho.

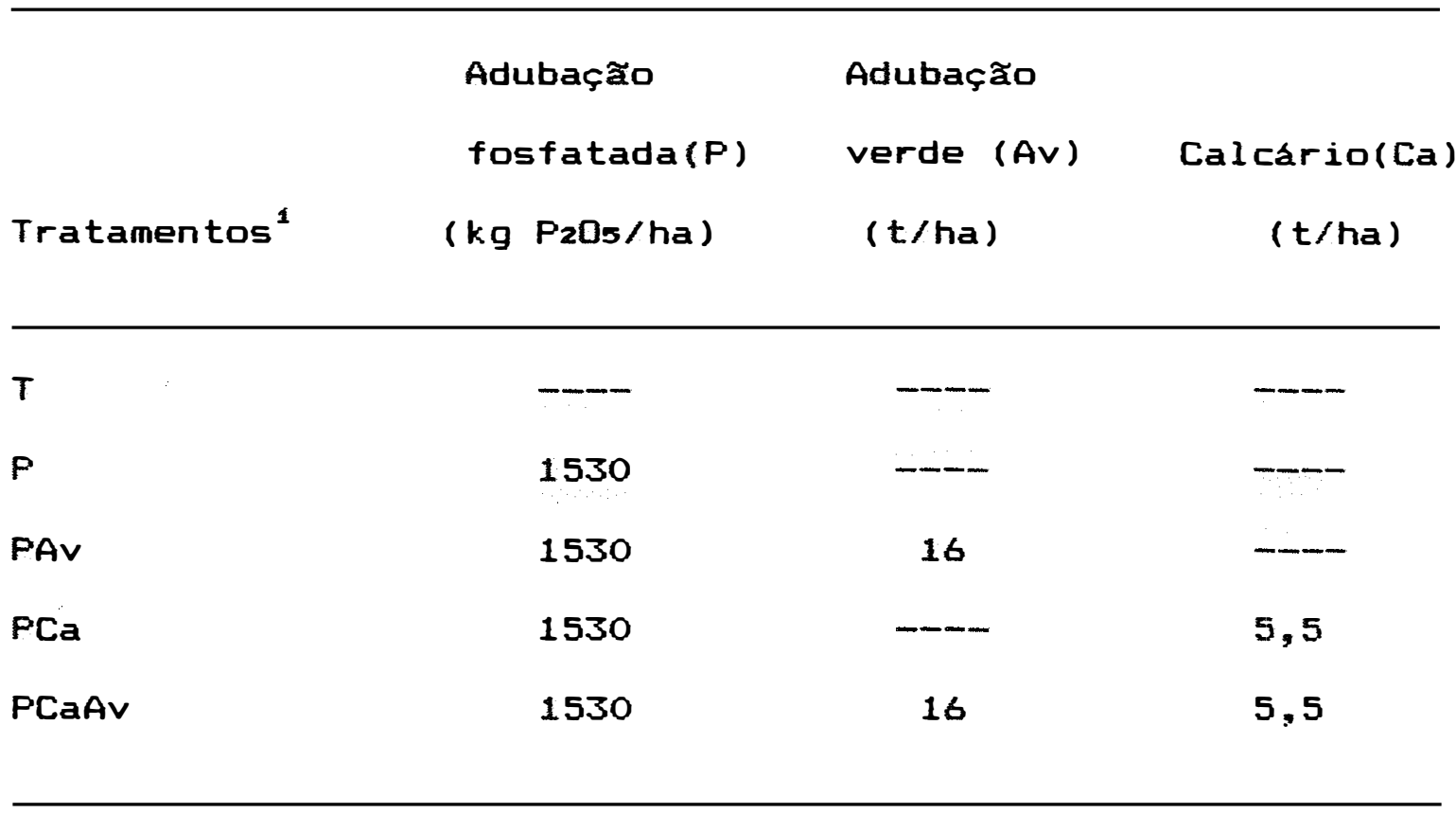

1. $T=$ testemunha; $P=$ fósforo; $P A v=$ fósforo + adubo verde; PCa = fósforo + calcário; PCaAv = fósforo + calcário + adubo verde.

A adubação fosfatada (P), comum aos tratamentos P, PAv, PCa e PCaAv, refere-se à aplicação de adubo da formula 5-30-15 na dose de 300kg/ha por cultivo, o que corresponde a um total de 1530kg de $\mathrm{P}_{205}$ por hectare lou 334 ppm de P, considerando-se a camada de incorporação do adubo de $0-20 \mathrm{~cm})$. 0 adubo usado $(5-30-15)$ é composto 
de fosfato de amónio (MAP) e/ou superfosfato triplo, uréia e cloreto de potássio.

A adubação verde (Av) refere-se à incorporação ao solo, da parte aérea de guandu (Cajanus cajan), cortado na época da floração. A adubação verde foi realizada no primeiro, no décimo e no décimo-sexto cultivos (novembro/82, novembro/85 e novembro/88, respectivamente). Nas parcelas dos demais tratamentos, nesses cultivos, plantou-se arroz (primeiro e décimo cultivos) e milho (décimo-sexto cultivo). - total de matéria seca da parte aérea do guandu incorporada ao solo correspondeu a 16 t/ha assim distribuldas: 4 tha no primeiro cultivo, 6 t/ha no décimo e 6 t/ha no décimo sexto cultivo.

A calagem (Ca) foi feita utilizando-se calcário dolomítico. Aplicaram-se 2,5 t/ha em 1982, antes do primeiro cultivo, e 3 t/ha em 1985, entre o nono e o décimo cultivos. Metade de cada dose foi aplicada antes da aração e metade antes da gradagem. As doses indicadas correspondem a calcário com PRNT igual a 100\%.

As amostras de solo utilizadas no presente trabalho foram retiradas das camadas de $0-20,20-40$ e 40 - $60 \mathrm{~cm}$, nas quatro parcelas (repetiçชes) dos tratamentos referidos na Tabela 1. As amostras de cada tratamento foram compostas de oito sub-amostras (duas por repetiçao), coletadas em pequenas trincheiras abertas a cinco metros dos cantos das parcelas, no sentido diagonal das mesmas. As oito 
sub-amostras foram secas ao ar, passadas em peneira com malha de $2 \mathrm{~mm}$, misturadas em partes iguais e homogeneizadas.

\subsection{Análises química e fisica}

As amostras de solo foram analisadas segundo procedimentos descritos em CAMARGO et al. (1986), exceto para extração do sulfato e determinação do nitrato. Na amostra da testemunha (T), determinou-se a granulometria e os teores de oxidos de ferro e aluminio, livres e amorfos (tabela 2). As demais análises (tabela 3) foram feitas nas amostras de todos os tratamentos.

Tabela 2 - Granulometria $e$ teores de oxidos de ferro e aluminio do latossolo vermelho-escuro utilizado no trabalino.

Sxidos

\begin{tabular}{|c|c|c|c|c|c|c|c|c|}
\hline \multirow[b]{2}{*}{ Camada } & \multicolumn{4}{|c|}{ Granulometria } & \multicolumn{2}{|c|}{$\mathrm{CDB}$} & \multicolumn{2}{|c|}{ Oxalato } \\
\hline & $A G$ & AF & $\mathrm{Si}$ & Arg & $\mathrm{Fe}_{2} \mathrm{Oa}$ & $\mathrm{A} 12 \mathrm{Ds}$ & $\mathrm{Fe}_{2} \mathrm{O}_{3}$ & Al 203 \\
\hline$(\mathrm{Cm})$ & & --- & . & --- & $-\%$ & -ーーー & -ーーー & -ーー- \\
\hline $0-20$ & 21 & 20 & 16 & 43 & 9,8 & 2,0 & 0,2 & 0,4 \\
\hline $20-40$ & 20 & 20 & 14 & 46 & 10,1 & 2,0 & 0,2 & 0,4 \\
\hline $40-60$ & 20 & 17 & 10 & 53 & 10,4 & 1,9 & 0,2 & 0,4 \\
\hline
\end{tabular}
$A G=$ areia grossa; $A F=$ areia fina; $5 i=$ silte; Arg = argila. 
Tabela 3 - Atributos quimicos do latossolo vermelho-escuro nos diversos tratamentos.

\begin{tabular}{|c|c|c|c|c|c|c|c|c|c|c|c|}
\hline \multirow[b]{2}{*}{ Tratamentos 1} & \multicolumn{2}{|c|}{$\mathrm{pH}(1: 2,5)$} & \multicolumn{5}{|c|}{ Trocáveis } & \multirow{2}{*}{ M.O. } & $P$ & \multirow[t]{2}{*}{$\mathrm{SO}_{4}^{2-}$} & \multirow{2}{*}{$\mathrm{NO}_{3}^{-}$} \\
\hline & água & $\mathrm{KCl}$ & $\mathrm{Ca}$ & $M g$ & $k$ & $\mathrm{Na}$ & Al & & & & \\
\hline & & & $\cdots$ & $-\cdots$ & meq/100g & $-\cdots$ & $-\cdots-\infty$ & $\%$ & , & $\mu g / g \mathrm{~m}$ & peqroog \\
\hline \multicolumn{12}{|l|}{$0-20 \mathrm{~cm}$} \\
\hline$T$ & 5.3 & 4.5 & 0.6 & 0.4 & 0.14 & 0,05 & 0.2 & 2.5 & 8 & 8 & 0.02 \\
\hline$P$ & 5,4 & 4,6 & 1,0 & 0,4 & 0,29 & 0,05 & 0,1 & 2.6 & 26 & 10 & 0,02 \\
\hline PAv & 5.6 & 4.5 & 0.8 & 0.3 & 0.32 & 0.05 & 0.5 & 2.6 & 28 & 10 & 0.03 \\
\hline PCa & 5,8 & 5,0 & 1,5 & 0,5 & 0,31 & 0,06 & 0,4 & 2,5 & 25 & 6 & 0.03 \\
\hline PCaAv & 5.9 & 5.0 & 1,6 & 0,6 & 0,32 & 0.05 & 0,1 & 2.5 & 26 & 7 & 0.03 \\
\hline \multicolumn{12}{|l|}{$20-40 \mathrm{~cm}$} \\
\hline$T$ & 5.2 & 4.5 & 0.4 & 0.2 & 0.05 & 0.04 & 0.1 & 1,9 & 6 & 20 & 0.02 \\
\hline$P$ & 5,3 & 4,5 & 0,6 & 0,2 & 0,07 & 0,05 & 0,2 & 2,0 & 8 & 24 & 0,03 \\
\hline Pav & 5,1 & 4.6 & 0.6 & 0.2 & 0,10 & 0,05 & 0,4 & 2.0 & 11 & 24 & 0.04 \\
\hline PCa & 5,5 & 4,9 & 1,1 & 0,3 & 0,13 & 0,06 & 0,4 & 1,9 & 7 & 17 & 0,03 \\
\hline PCaAv & 5,7 & 5,0 & 1,3 & 0,4 & 0.12 & 0,04 & 0,1 & 1,9 & 11 & 11 & 0.03 \\
\hline \multicolumn{12}{|l|}{$40-60 \mathrm{~cm}$} \\
\hline$T$ & 5.3 & 5.0 & 0.2 & 0,2 & 0.04 & 0.04 & 0.0 & 1.3 & 6 & 10 & 0.03 \\
\hline$P$ & 5,4 & 5,1 & 0,5 & 0,2 & 0,07 & 0,04 & 0,4 & 1,3 & 4 & 26 & 0,03 \\
\hline PAV & 5,5 & 5,0 & 0.7 & 0.2 & 0.08 & 0.04 & 0.1 & 1,4 & 4 & 30 & 0,04 \\
\hline PCa & 54 & 5.0 & 0,6 & 0,2 & 0,04 & 0,04 & 0,4 & 1,4 & 6 & 44 & 0,03 \\
\hline PCaAv & 5,6 & 5,3 & 0.6 & 0.3 & 0,06 & 0.04 & 0,1 & 14 & 6 & 35 & 0.04 \\
\hline
\end{tabular}

1. $T=$ testemunha; $P=$ fosforo; $P A V=$ fosforo + adubo verde; $P C a=$ fósforo + calcário; PCaAv = fósforo + calcário + adubo verde. 


\section{a. Granulometria}

A análise granulométrica das amostras foi feita após dispersão com solução de hidróxido de sódio a $0,4 \%$ + hexametafosfato de sodio a 1\%. Argila e silte foram determinados pelo metodo da pipeta (KILMER \& ALEXANDER, 1949). Os teores de areia grossa e areia fina foram determinados, respectivamente, pela pesagem do material disperso retido em peneira com malha de $0,2 \mathrm{~mm}$, e por diferença entre $100 \%$ e a soma dos teores de areia grossa, silte e argila.

\section{b. Oxidos livres de ferro e aluminio}

Os óxidos livres foram solubilizados por tratamento do solo com citrato-ditionito-bicarbonato de sódio (CDB), após eliminação da matéria orgănica com $\mathrm{H}_{2} \mathrm{O}_{2}$ (JACKSON, 1969). Ferro e aluminio nos extratos foram determinados por colorimetria, usando-se os métodos da ortofenantrolina e do aluminon, respectivamente. A determinação do aluminio foi feita após a eliminação do citrato presente nos extratos, mediante oxidação com ácidos nitrico e sulfúrico, seguida de queima em mufla, a $450^{\circ} \mathrm{C}$, por tres horas. 


\section{c. Oxidos amorfos de ferro e aluminio}

Utilizou-se o método de agitação do solo com solução de ácido oxálico + oxalato de amónio, no escuro (MCKEAGUE \& DAY, 1966). Ferro e aluminio nos extratos foram determinados pelos métodos referidos anteriormente (b).

d. pH em água e em KCl $1 \mathrm{M}$

0 pH foi medido em potenciómetro, após agitação das suspensơes (relação solo: agua ou solução de kCl IM 1:2,5) por quinze minutos e repouso por trinta minutos. Durante as medidas o eletrodo de referéncia ficava imerso no sobrenadante e o eletrodo de vidro tocava o sedimento (PEECH, 1965).

e. Aluminio trocável

o aluminio foi extraido por agitação de uma amostra de $5 \mathrm{~g}$ de solo com $100 \mathrm{ml}$ de solução de KCl $1 \mathrm{~N}$ durante dez minutos e repouso da suspensão por dezesseis horas. Após filtração, o extrato foi titulado com solução de $\mathrm{NaOH} 0,1 \mathrm{~N}$, usando-se fenolftaleina como indicador. 


\section{f. Cátions trocáveis}

Os cátions trocáveis foram extraidos com acetato de amónio $1 \mathrm{~N}$ pH 7,0 usando-se a relação solo: extrator de 1:10. Os tempos de agitaçăo e repouso foram os mesmos do item (e). Cálcio e magnésio nos extratos foram determinados por espectrofotometria de absorção atómica, e potássio e sódio por fotometria de chama.

\section{Carbono orgånico}

Utilizou-se o método de WALKLEY \& BLACK (1934) modificado, que consiste na oxidação do carbono orgânico do solo com solução de dicromato de potássio em presença de ácido sulfúrico, e titulaçăo do excesso de dicromato com solução de sulfato ferroso amoniacal.

\section{h. Fósforo extrafvel}

o fósforo foi extraldo com resina trocadora de ions (RAIJ \& QUAGGIO, 1983) e determinado pelo metodo de MURPHY \& RILEY (1962). 


\title{
i. Sulfato
}

\begin{abstract}
0 sulfato foi extraldo com solução de $\mathrm{Ca}\left(\mathrm{H}_{2} \mathrm{PO}_{4}\right)_{2} \cdot \mathrm{H}_{2} \mathrm{O}$ contendo $500 \mathrm{ppm}$ de $\mathrm{F}(\mathrm{FOX}$ et al., 1964) e determinado por turbidimetria (BARDSLEY \& LANCASTER, 1965).
\end{abstract}

\section{j. Nitrato}

Utilizou-se como extrator uma solução de Na2SO4 $1 N$ (ONKEN \& SUNDERMAN, 1977). 0 nitrato foi determinado por colorimetria, usando-se o método da brucina (BAKER, 1969).

\subsection{Caracteristicas eletroquimicas}

Algumas caracteristicas eletroquimicas dos solos de carga variável que podem ser afetadas pela calagem e por adubações, foram estudadas. Determinaram-se: ponto de carga zero (PCZ), carga eletrica liquida, capacidade de troca de cátions (CTC) e capacidade de troca de anions (CTA) ao pH do solo e capacidade de troca de cátions ao pH 7,0 (CTC pH $7,0)$ 
a. Ponto de carga zero (PCZ) e carga eletrica Iiquida

\begin{abstract}
o PCZ e a carga eletrica liquida foram determinados nas amostras de solo saturadas com $\mathrm{H}^{+}$. A saturação foi feita mediante percolação das amostras com HCl $0,1 \mathrm{~N}$ (500 ml para $200 \mathrm{~g}$ de solo), seguida de lavagem com água deionizada até eliminação do excesso de cloreto.
\end{abstract}

Utilizou-se o método das curvas de titulação potenciométrica. Esse metodo, descrito em detalhes por CAMARGO et al. (1986), segue em essência os procedimentos estabelecidos por RAIJ \& PEECH (1972), para o estudo das propriedades eletroquímicas dos solos de carga variável. A carga elétrica liquida a pH diferente do PCZ é estimada por interpolação na(s) curva(s) de titulação, conforme a concentração de eletrólitos desejada. A concentração escolnida deve ser a que mais se aproxima da força iónica da solução do solo, para que a carga liquida estimada reflita as condiçôes naturais do solo.

A força iónica da solução do solo foi determinada de forma indireta, segundo método descrito por GILLMAN \& BELL (1978). As amostras foram equilibradas por vinte e quatro horas com água deionizada, usando-se relaçăo solo:água de 1:5. Após o equilfbrio, as suspensơs foram filtradas, determinando-se a condutividade elétrica dos extratos. A força iónica da solução de cada amostra de solo 
foi calculada atraves da fórmula:

$$
I=0,0446 C-0,000173 \text { (GILLMAN \& BELL, 1978), }
$$

onde I representa a força iónica da soluçăo do solo com umidade correspondente a 0,1 bar e C a condutividade do extrato $1: 5(\mathrm{~m} 5 / \mathrm{cm})$.
b. Capacidade de troca de cátions e de ânions ao $\mathrm{pH}$ do solo

As capacidades de troca de cátions (CTC) e ânions (CTA) ao pH natural foram determinadas segundo método de GILLMAN (1979). Efetuou-se a saturação do complexo de troca do solo com lons $\mathrm{Ba}^{2+}$ e $\mathrm{Cl}^{-}$, por equilibrio do solo com uma soluçăo de Bacli $2 \times 10^{-9} \mathrm{M}$, não tamponada. Após o equilibrio e a centrifugaçăo da suspensão, os $10 n s \mathrm{Ba}^{2+}$ e $\mathrm{Cl}^{-}$ adsorvidos pela amostra de solo foram deslocados, respectivamente, por $\mathrm{Mg}^{+2}$ e $\mathrm{SO}_{4}{ }^{2-}$ de uma solução de Mgso. $5 \times 10^{-9} \mathrm{M} . \quad \mathrm{Ba}^{2+}$ adsorvido (correspondente à CTC ao $\mathrm{pH}$ do solo) foi determinado de forma indireta, através da determinação do $\mathrm{Mg}^{2+}$ remanescente na solução de equilibrio. $0 \mathrm{Mg}^{2+}$ foi determinado por espectrofotometria de absorça atómica. $0 \mathrm{Cl}^{-}$adsorvido (correspondente à CTA ao pH do solo) foi determinado por titulação potenciométrica, em clorómetro. Detalhes do método constam em CAMARGo et al. 
(1986).

\section{c. Capacidade de troca de cátions ao $\mathrm{pH} 7,0$}

A capacidade de troca de cátions a pH 7,0 (CTC pH 7,0) foi determinada mediante saturação do complexo de troca do solo com cálcio, ao pH 7,0 e determinação da quantidade adsorvida, da seguinte maneira (CAMARGO et al., 1986): uma amostra de solo de $1,00 \mathrm{~g}$ sofreu percolação lenta com $50 \mathrm{ml}$ de solução de acetato de cálcio $1 \mathrm{~N} p H$ 7,0 e posteriormente foi lavada com água deionizada e após com álcool. O cálcio adsorvido (considerado equivalente à CTC ao pH 7,0), foi deslocado por percolação com solução de acetato de sódio $1 \mathrm{~N}$ pH 7,0 e determinado por espectrofotometria de absorção atômica.

\subsection{Adsorçăo aniônica}

\section{a. Adsorçăo de fósforo}

A capacidade de adsorção de fósforo das amostras de solo foi avaliada pelo método das isotermas de adsorção. Os testes foram feitos nas camadas de 0-20 e 20-40 cm, admitindo-se que os efeitos dos tratamentos ficariam restritos a essas duas camadas. Amostras de solo de 2,5 9, em duplicata, foram agitadas por quarenta e oito horas com 25 $\mathrm{ml}$ de sete soluçช̄es de $\mathrm{KH}_{2} \mathrm{PO}_{4}$, cujas concentraçð̋es variaram 
entre $6,7 \times 10^{-4} \mathrm{M}$ e $2,46 \times 10^{-3} \mathrm{M}$. As soluçб̆es foram preparadas em $\mathrm{KCl} 2 \times 10^{-2} \mathrm{M}$, de modo a manterem força iónica aproximadamente uniforme. Para cada amostra adicionou-se uma gota de tolueno, para eliminar a atividade de microorganismos. Após a agitação as suspensơes foram filtradas, e determinou-se o fósforo remanescente em soluçăo, pelo metodo de MURPHY \& RILEY (1962). 0 fósforo adsorvido pelo solo foi estimado pela diferença entre as concentraçß̧es inicial e final na solução de equilibrio. As isotermas, construldas com sete pares de pontos experimentais por tratamento (Apendice 2) foram ajustadas à equação de Freundlich. Essa equação tem a forma:

$$
Y=A C^{1 / n}
$$

onde $Y$ representa a quantidade de fósforo adsorvido $(\mu g / g)$ e C a concentração de fósforo na solução em equilibrio com o solo $(\mu g / m 1)$. A e n são parămetros que, embora não tenham significado físico-químico, apresentam estreita correlaçăo com a capacidade máxima de adsorção de fósforo e com a constante de afinidade fóforo-solo, respectivamente (MEAD, 1981). As equaçớs das isotermas foram definidas por análise de regressão não linear, usando-se o metodo do quadrado minimo residual. 


\section{b. Adsorção de sulfato}

A capacidade de adsorção de sulfato do solo foi avaliada também pelo método das isotermas de adsorção, nas amostras das camadas de $0-20,20-40$ e $40-60 \mathrm{~cm}$, nos cinco tratamentos estudados. Para tanto, amostras de 2,59 , em duplicata, foram agitadas por vinte e quatro horas com $25 \mathrm{ml}$ de cada uma de nove soluçơes de K2S04 com concentraçơs variando entre $1,04 \times 10^{-9} \mathrm{M}$ e $13,75 \times 10^{-9} \mathrm{M}$. As soluçðes foram preparadas em KCl $2 \times 10^{-2} \mathrm{M}$, visando uniformizar a força iônica delas. Após a agitaçăo as suspensơes foram filtradas, e os teores de sulfato remanescente nas soluçơes foram determinados por turbidimetria (BARDSLEY \& LANCASTER, 1965 ). As quantidades de sulfato adsorvidas pelo solo foram estimadas pela diferença entre as concentraçơes inicial e final nas soluçỡes de equilibrio.

As isotermas, construidas com nove pares de pontos experimentais para cada tratamento (Apéndice 3) foram ajustados à equação de Freundlich $\left(Y=A C^{1 / n}\right)$. Os termos da equação têm os mesmos significados já descritos na parte referente a adsorção de fósforo, e são igualmente aplicáveis ao caso do sulfato. A equação foi escolhida com base no trabalho de SINGH (1984): que constatou sua superioridade em relação a outras equaçơes na descrição da adsorção de sulfato em solos ácidos. As equaçớs das isotermas foram definidas por análise de regressão não 
linear, usando-se o método do quadrado mínimo residual.

\section{c. Adsorçăo de nitrato}

A capacidade de adsorção de nitrato do solo foi avaliada pelo método descrito por BLACK \& WARING (1976). Amostras de $13,0 \mathrm{~g}$ de solo, em duplicata, foram agitadas durante duas horas com $20 \mathrm{ml}$ de solução de $\mathrm{KNO}_{3} 5 \times 10^{-3} \mathrm{M}$. Após a agitação, as suspensões foram filtradas, e procedeu-se à determinação do nitrato remanescente em solução, usando-se - método colorimétrico da brucina (BAKER, 1969). 0 nitrato retido, considerado equivalente à capacidade de retença de nitrato do solo, foi estimado pela diferença entre o nitrato adicionado mais o nitrato do solo, e o nitrato remanescente em solução. O nitrato do solo foi extraido con solução de Naz50. IN (ONKEN \& SUNDERMAN, 1977) e determinado pelo método da brucina (BAKER, 1969).

\subsection{Comparaçáo entre os tratamentos}

Os resultados experimentais relativos ao PCZ, à carga líquida negativa, às capacidades de troca de cátions (CTC) e de ånions (CTA), e à adsorção de nitrato, foram comparados descritivamente, segundo a tendéncia dos dados.

Os valores dos parâmetros $A$ e $n$ das equações das isotermas de adsorção de fosfato e sulfato, nos diversos 
tratamentos, foram comparados com base nos intervalos de confiança a 95\% (IC 95\%) determinados para os mesmos. Quando os IC 95\% calculados para valores distintos de um mesmo paråmetro apresentaram sobreposição, considerou-se que tais valores não diferiram significativamente entre si. Na ausência de sobreposição dos IC $95 \%$, os valores dos parametros foram considerados estatisticamente diferentes $(p<0,05)$. 
4. RESULtADOS E DISCUSSAOO

4.1. Efeito dos tratamentos sobre as propriedades eletroquimicas do solo

4.1.1. Ponto de carga zero (PCZ) e carga eletrica liquida

As figuras 1 a 3 mostram as curvas de titulação potenciométrica e os valores do PCZ das amostras de solo, o qual corresponde ao ponto de cruzamento das tres curvas. Os dados experimentais relativos a cada curva encontram-se no Apêndice 1 .

Os valores de PCZ obtidos são comparáveis aqueles determinados para oxissolos de outras regižes do pals (RAIJ \& PEECH, 1972; MORAIS et al., 1976). Nota-se que o PCZ aumentou em profundidade, passando de valores entre 3,5 e 3,7 na camada de $0-20 \mathrm{~cm}$, para 3,7 a 3,8 e 4,3 a 4,6 nas camadas de $20-40 \mathrm{~cm}$ e $40-60 \mathrm{~cm}$, respectivamente. 0 mesmo comportamento foi observado por aqueles autores. 


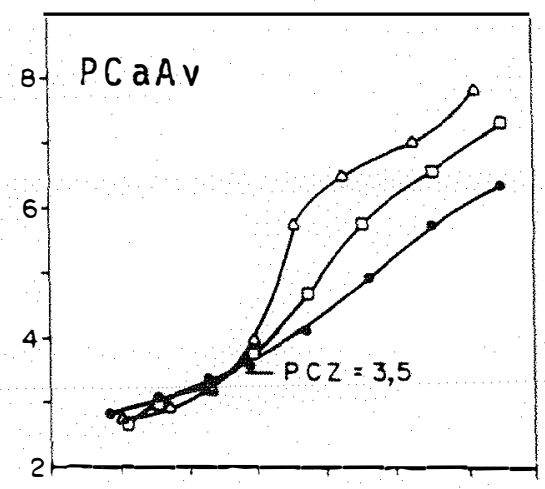
- KCI $0,1 \mathrm{M}$
$\square \mathrm{KCT} 0,01 \mathrm{M}$
$\triangle \mathrm{KCl} 0,001 \mathrm{M}$
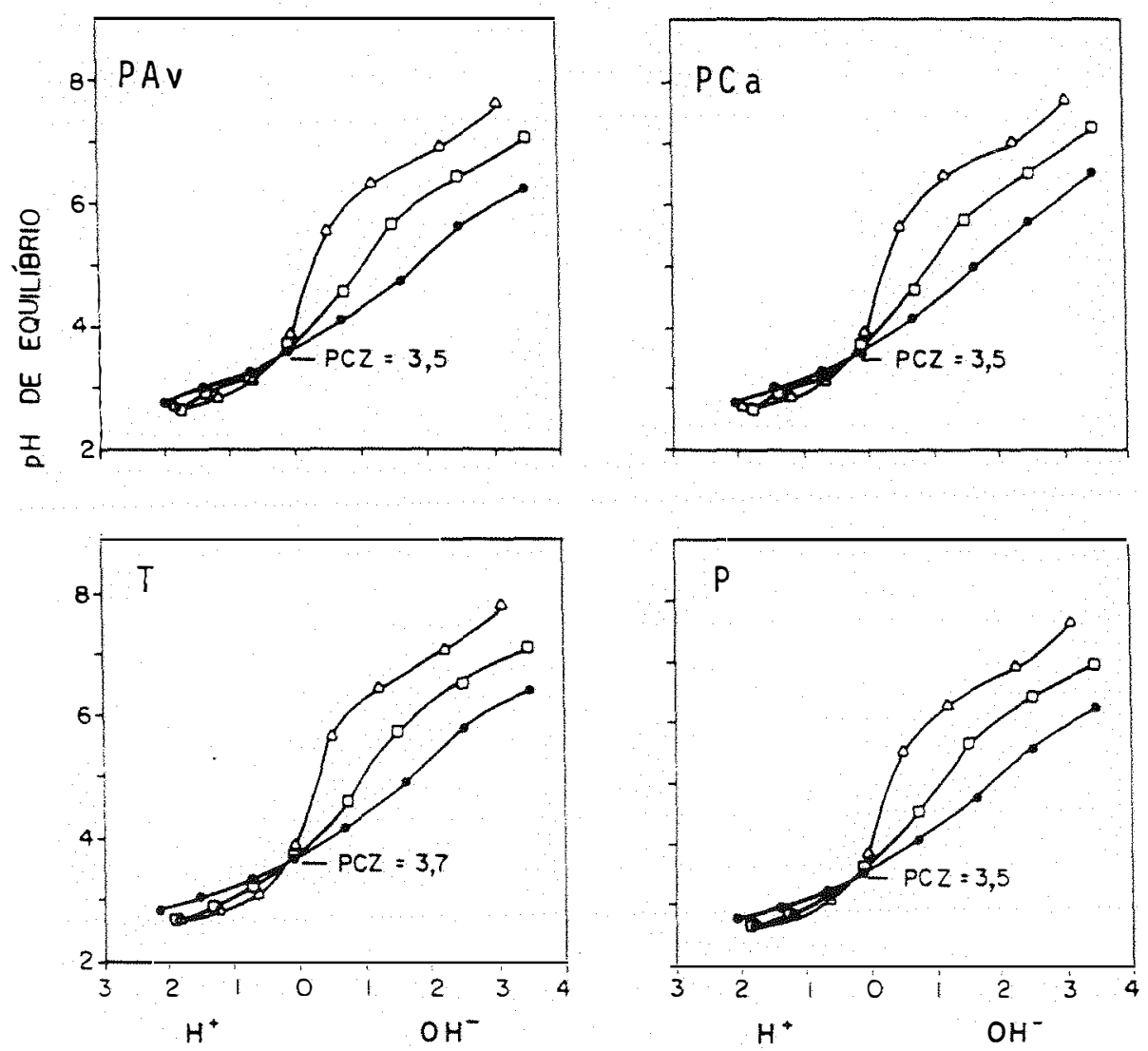

$\mathrm{H}^{+} / \mathrm{OH}^{-}$ADSORVIDO (mea/1OOg)

Figura 1 - Curvas de titulação potenciometrica das amostras do latossolo vermelho-escuro na camada de $0-20 \mathrm{~cm}$. $(T=$ testemunina: $P=$ fosforo; $P A v=$ fosforo + adubo verde; $\mathrm{PCa}=$ fófforo + calcário: PCaAv = fósforo + calcário + adubo verdel. 


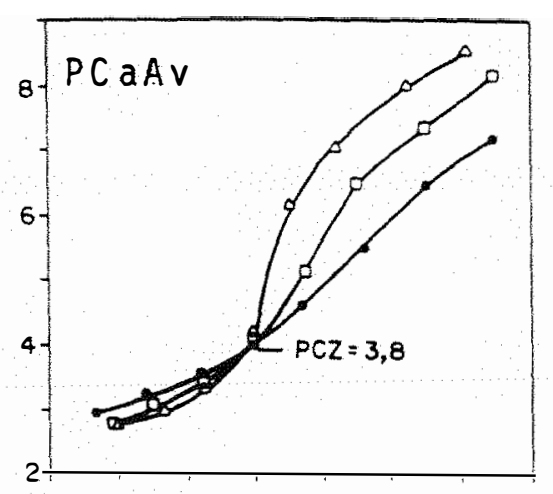

- $K C>0,1$

- $\mathrm{KCl} 0,01 \mathrm{M}$

$\triangle \mathrm{KCl} 0,001 \mathrm{M}$
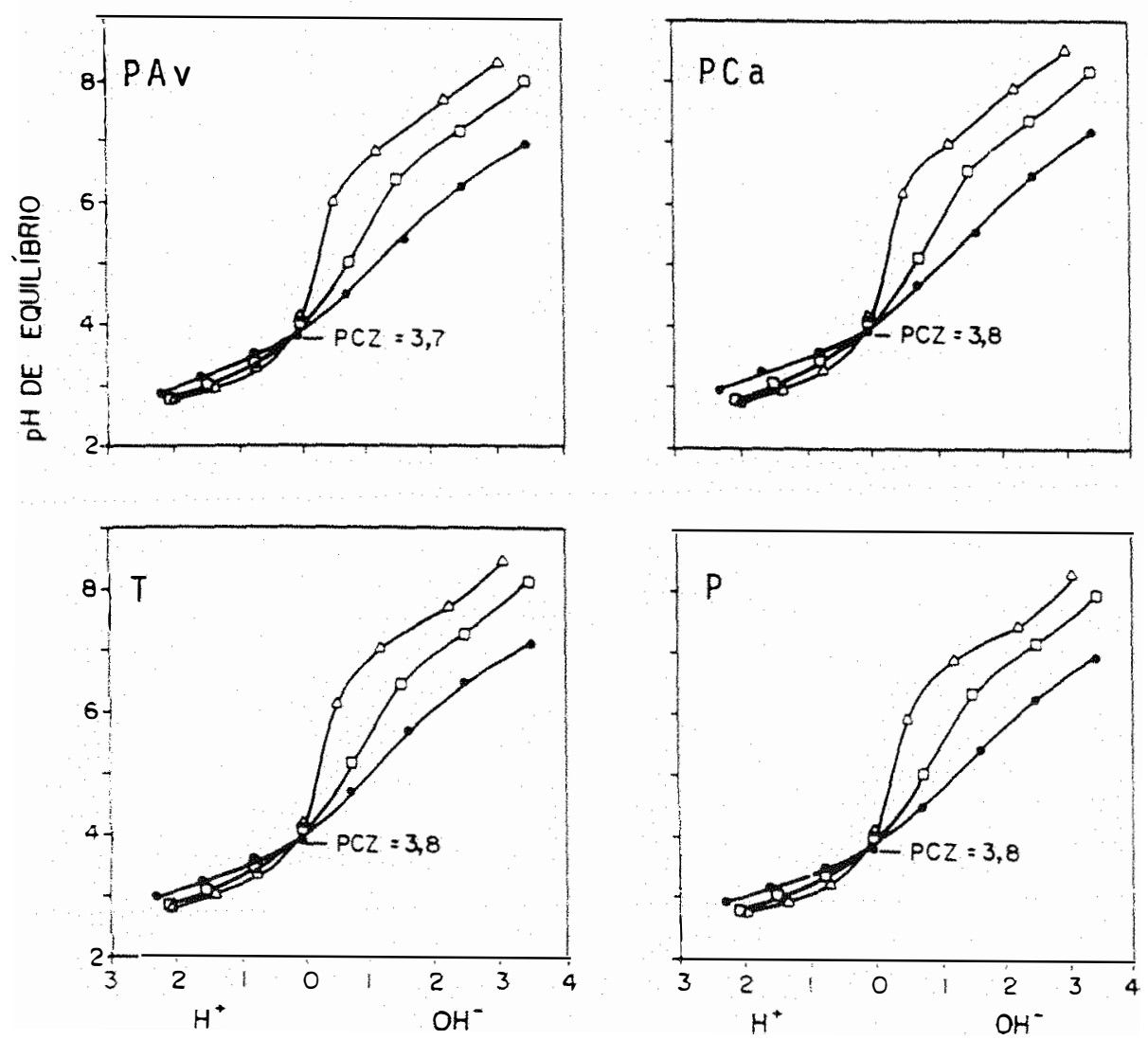

$\mathrm{H}^{+} / \mathrm{OH}^{-}$ADSORVIDO (meq/1OOg)

Figura 2 - Curvas de titulaçăo potenciometrica das amostras do latossolo vermelho-escuro na camada de $20-40 \mathrm{~cm}$. $(T=$ testemunha; $P=$ fosforo; $P A v=$ fosforo + adubo verde; $\mathrm{PCa}=$ fosforo + calcário PCaAv = fósforo + calcário + adubo verde). 


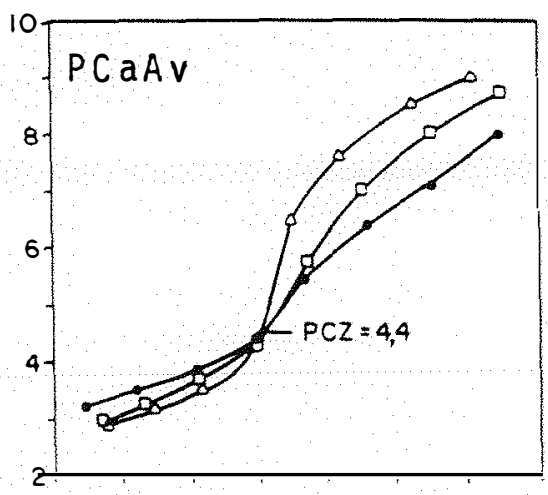
- KCT $0,1 \mathrm{M}$
KC $0,01 M$
$\triangle \quad K C>0,001 \mathrm{M}$
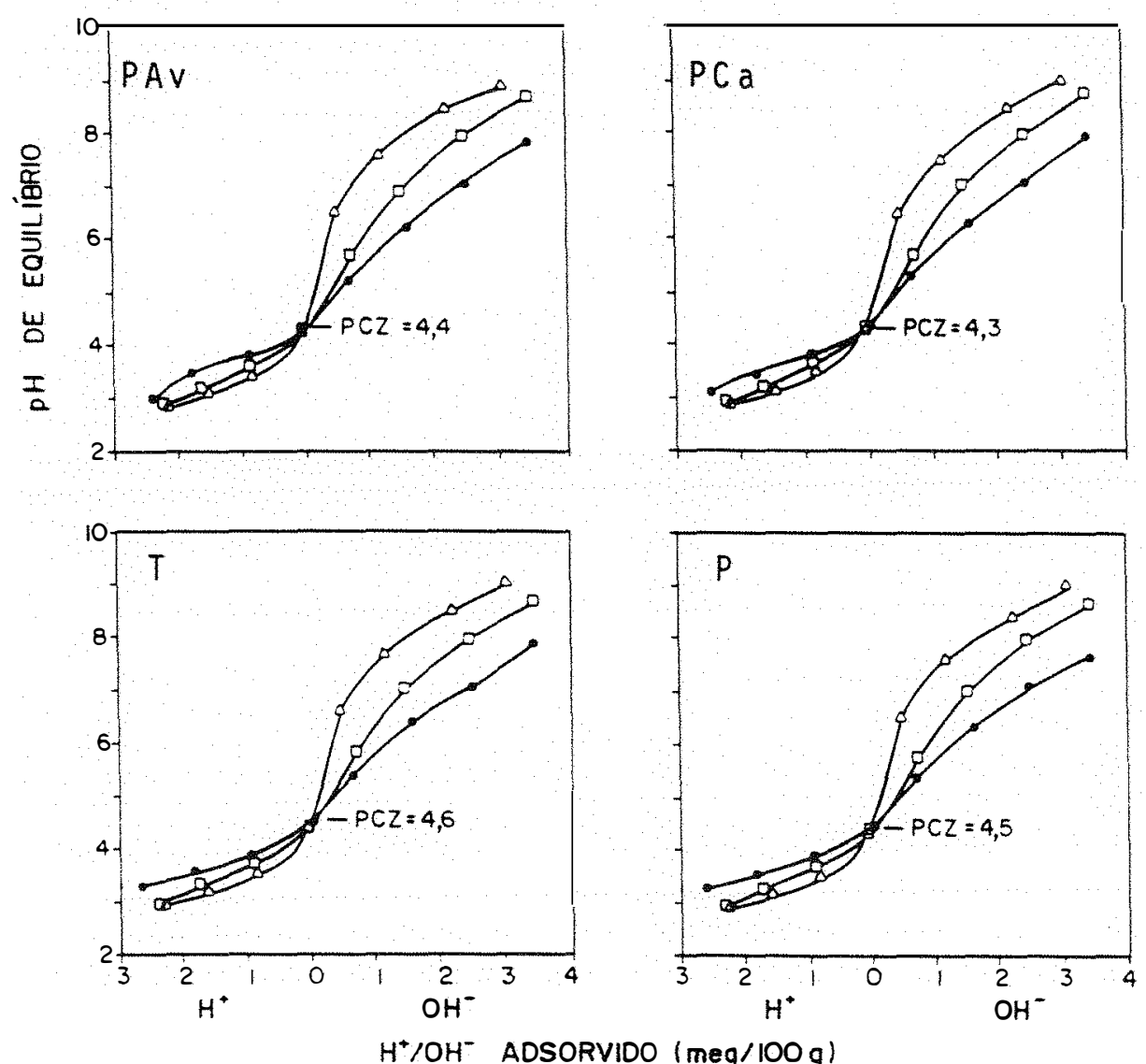

Figura 3 - Curvas de titulaçăo potenciometrica das amostras do latossolo vermelho-escuro na camada de 40 - $60 \mathrm{~cm}$. $\quad(T=$ testemunha; $P=$ fósforo; $P A V=$ fósforo + adubo verde; $\mathrm{PCa}=$ fósforo + calcário; PCaAy = fósforo + calcário + adubo verde). 
o aumento do PCZ é explicado pela diferença nos teores de matéria orgânica entre as trés camadas que apresentaram teores medios de cima para baixo de 2,5, 1,9 e 1,1\%, (tabela 3 ), pois sabe-se que existe uma correlação negativa entre esse parămetro e o conteúdo de matéria orgánica nas diversas camadas do perfil dos solos, conforme observado por SIQUEIRA et al. (1990).

Em cada camada de solo, os valores do PCZ apresentaram variaçðes pequenas. As diferenças máximas entre tratamentos foram de $0,2,0,1$ e 0,3 unidades de $\mathrm{pH}$, nas camadas de $0-20,20-40$ e $40-60 \mathrm{~cm}$, respectivamente. 0 exame das curvas de titulação, que foram praticamente idênticas em cada camada de solo, mostra alguma indefinição na exata posição do PCZ (de alguns décimos de pH) en virtude do não cruzamento delas no mesmo ponto. o fato é comum nesse tipo de determinação e, segundo RAIJ (1973), não parece ser decorrente de erro experimental. Frente a incerteza na determinação do valor do parâmetro, admite-šse que as diferenças entre os tratamentos. estão dentro da margen de erro do método gráfico utilizado e, portanto, são casuais. Este fato indica que a calagem, a adubação fosfatada e a adubação verde, nos níveis utilizados, não afetaram de modo significativo o PCZ do latossolo vermelho-escuro estudado. A primeira vista, tal observação parece ser conflitante com resultados de outros trabalios, em que se constatou redução do PCZ como consequência da aplicação de fosfato a solos de 
carga variável (WANN \& UEHARA, 1978; LAVERDIERE, 1982). Nesses trabalhos, todavia, os efeitos do fosfato foram avaliados mediante sua incubaçăo com o solo sob condiçశes de laboratório ou de casa de vegetaçăo, em periodos de tempo relativamente curtos. Ademais, as doses de fosfato foram aplicadas de uma só vez.

No presente trabaliho, o fosfato foi aplicado parceladamente, en doses baixas, e ao longo de seis anos, perfazendo um total de 334 ppm de P laproximadamente 20 ppm de P por cultivo, em dezessete cultivas). Por outro lado, as amostras de solo para a determinação do PCZ foram coletadas dois anos após a término dos cultivos. Portanto, os resultados refletem o efeito residual e cumulativo de longo prazo dos tratamentos, em condiçơses de campo. Deve-se ressaltar também que nos trabalihos citados, efeitos consideráveis sobre a redução do PCZ foram registrados somente com doses relativamente altas de fosfato (entre 250 e 1500 ppm de PJ. Dose menor, como por exemplo 100 ppm de P, usada por WANN \& UEHARA (1978), praticamente não alterou o PCZ do oxissolo por eles estudado. Assim, os resultados aqui relatados são coerentes com os da literatura, quando demonstram que aplicaçชes seqúenciais de pequenas doses de fosfato, em condiçชes de campo, praticamente não modificam o PCZ do solo.

Năo se constatou diferença entre o PCZ das amostras de solo dos tratamentos com ausencia e presença da 
adubação verde. Embora haja evidência de que a matéria orgånica contribua para baixar o PCZ, não existem indicaçชes seguras de que isso possa ocorrer mediante práticas de manejo que favoreçam o aumento do teor de matéria orgânica dos solos (SANCHEZ, 1976). Em trabalho recente, com uma série de latossolos coletados em diversas regizes do pais, SIQUEIRA et al. (1990) verificaram que a incorporação de residuos culturais ou de adubo verde, por seis anos consecutivos, tendeu a abaixar o PCZ de um latossolo vermelho-escuro de cerrado, coletado em Planaltina (DF). No entanto, os autores não observaram correlação entre o PCZ e o teor de carbono orgånico das amostras do solo. As pequenas diferenças de PCZ constatadas por SIQUEIRA et al. (1990), entre tratamentos com presença e auséncia de adubação verde, e os resultados do presente estudo, indicam que com a incorporação de residuos de culturas e/ou de adubo verde, o PCZ do solo se mantém praticamente inalterado ao longo de vários anos.

Utilizando-se as curvas de titulação mostradas nas figuras 1 a 3 , determinou-se a carga eletrica liquida da amostra de solo de cada tratamento, nas tres camadas. Utilizou-se a curva de titulação correspondente à concentração salina de $0,001 \mathrm{M}$ em KCl, pois essa concentração foi a que mais se aproximou das forças iónicas das soluçชes das amostras, as quais variaram entre um minimo de $2,11 \times 10^{-4} \mathrm{M}$ na testemunha na camada de 40 - $60 \mathrm{~cm}$, e um máximo de $10,49 \times 10^{-4} \mathrm{M}$, no tratamento PCaAv, na camada de 0 - $20 \mathrm{~cm}$ 
(tabela 4 ).

Tabela 4 - Força iónica (I) da solução do latossolo vermelho-escuro nos diferentes tratamentos e camadas - medias de duas repetições.

\section{Tratamentos}

Camadas

\begin{tabular}{lllll}
\hline$T$ & $P$ & PAV & PCa & PCaAV
\end{tabular}

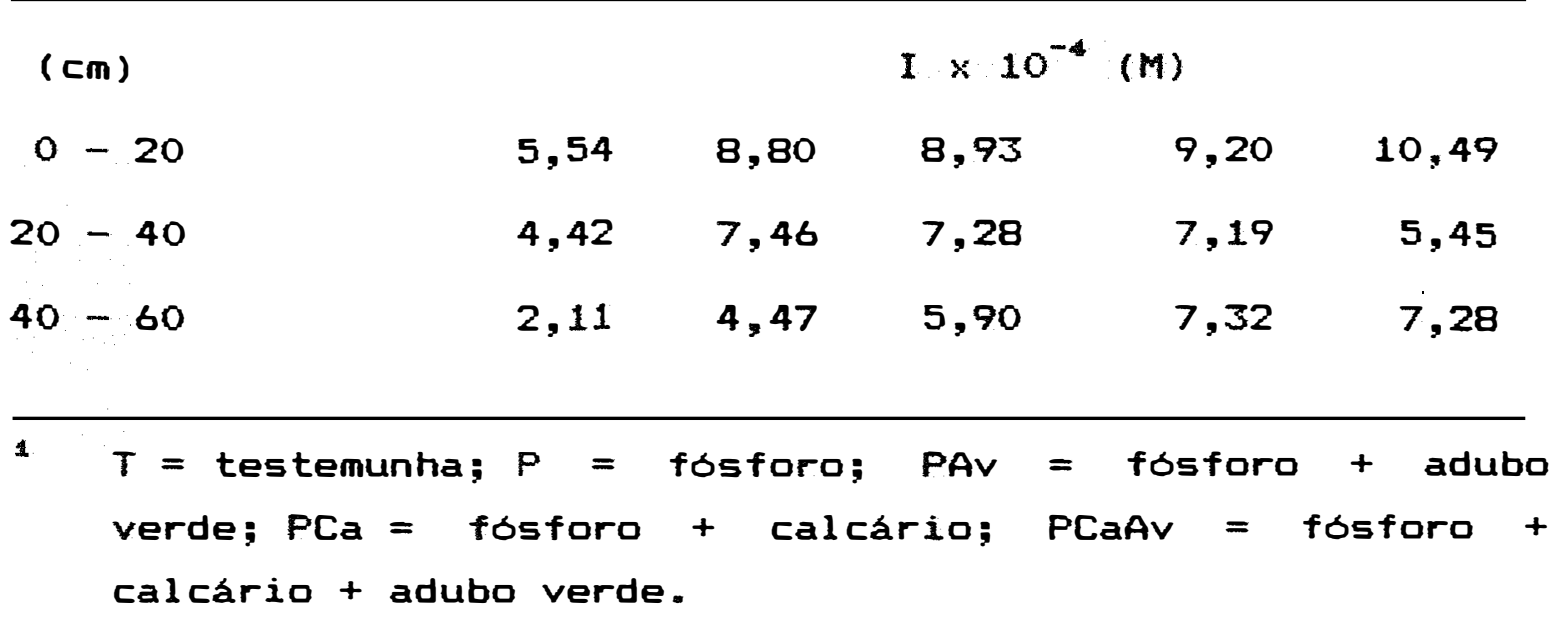

Considerando a projeção do ponto correspondente ao PCZ na abcissa, como o divisor entre as cargas negativas (lado direito; $\mathrm{OH}^{-}$adsorvido) $\mathrm{e}$ as positivas (lado esquerdo: $\mathrm{H}^{+}$adsorvido) (CAMARGo et al., 1986), determinou-se a carga liquida ao pH natural do solo e a pH 4,5 e 6,5. Os resultados constam da tabela 5 . 
Tabela 5 - Carga elétrica liquida do latossolo vermelhoescuro (meq/100g) nos diversos tratamentos, a três valores de $\mathrm{pH}$. Os valores foram estimados com base na curva de titulação em KCl $0,001 M$.

\begin{tabular}{|c|c|c|c|c|c|}
\hline \multirow[b]{2}{*}{$\mathrm{pH}$} & \multicolumn{5}{|c|}{ Tratamentos ${ }^{1}$} \\
\hline & $T$ & $\mathbf{P}$ & PAV & $\mathrm{PCa}$ & PCaAv \\
\hline \multicolumn{6}{|c|}{$0-20 \mathrm{~cm}$} \\
\hline 4,5 & $-0,2$ & $-0,3$ & $-0,4$ & $-0,4$ & $-0,4$ \\
\hline natural & $-0,4$ & $-0,7$ & $-0,8$ & $-0,9$ & $-0,9$ \\
\hline & $(5,3)^{2}$ & $(5,4)$ & $(5,6)$ & $(5,8)$ & $(5,9)$ \\
\hline \multirow[t]{2}{*}{6,5} & $-1,4$ & $-1,8$ & $-1,7$ & $-1,6$ & $-1,5$ \\
\hline & \multicolumn{4}{|c|}{$20-40 \mathrm{~cm}$} & \\
\hline 4,5 & $-0,4$ & $-0,4$ & $-0,4$ & $-0,3$ & $-0,3$ \\
\hline \multirow[t]{2}{*}{ natural } & $-0,7$ & $-0,6$ & $-0,6$ & $-0,5$ & $-0,6$ \\
\hline & $(5,2)$ & $(5,3)$ & $(5,1)$ & $(5,5)$ & $(5,7)$ \\
\hline \multirow[t]{2}{*}{6,5} & $-1,2$ & $-1,1$ & $-1,2$ & $-1,0$ & $-1,0$ \\
\hline & \multicolumn{4}{|c|}{$40-60 \mathrm{~cm}$} & \\
\hline 4,5 & $+0,1$ & 0,0 & 0,0 & $-0,1$ & 0,0 \\
\hline \multirow[t]{2}{*}{ natural } & $-0,2$ & $-0,2$ & $-0,2$ & $-0,2$ & $-0,3$ \\
\hline & $(5,3)$ & $(5,4)$ & $(5,5)$ & $(5,4)$ & $(5,6)$ \\
\hline 6,5 & $-0,3$ & $-0,5$ & $-0,5$ & $-0,5$ & $-0,5$ \\
\hline
\end{tabular}

$1 T=$ testemunha; $P=$ fosforo; $P A V=$ fósforo + adubo verde; $\mathrm{PCa}=$ fósforo + calcário PCaAv = fósforo + calcario + adubo verde.

2 Os números entre parénteses representam o $\mathrm{pH}$ natural do solo em cada tratamento e camada. 
Como se nota na tabela 5, a carga 11 quida das amostras das trés camadas estudadas e nos tres valores de pH estabelecidos foi predominantemente negativa. Apenas na camada de 40 - $60 \mathrm{~cm}$ ao $\mathrm{pH} \mathrm{4,5} \mathrm{a} \mathrm{carga} \mathrm{liquida} \mathrm{oscilou} \mathrm{em}$ torno de 0,0 meq/100g de solo, indicando que nesse pH e nessa profundidade, as cargas positivas e negativas teriam, aproximadamente, a mesma magnitude. Ao pH natural, nessa camada, o solo apresenta ainda pequena carga liquida negativa, entre $-0,2$ e $-0,3$ meq/100g. Observa-se tendência de diminuição da carga liquida negativa do solo com a profundidade, independentemente do $\mathrm{pH}$. Os resultados confirmam a tendência indicada pelos valores de $\Delta \mathrm{pH}$ negativos determinados para as amostras (tabela 6$)$, os quais decresceram com a profundidade.

Tabela 6 - Valores de $\Delta p H$ do latossolo vermelho-escuro nos diversos tratamentos e camadas.

\section{Tratamentos ${ }^{1}$}

Camadas

$T$

$P$

PAv

PCa

PCaAv

$0-20 \mathrm{~cm}$

$-0,8 \quad-0,9 \quad-1,1$

$-0,8 \quad-0,9$

$20-40 \mathrm{~cm}$

$-0,7 \quad-0,8$

$-0,5$

$-0,6$

$-0,7$

$40-60 \mathrm{~cm}$

$-0,3 \quad-0,3$

$-0,5$

$-0,5$

$-0,3$

$1 T=$ testemunha; $P=$ fosforo; PAv = fosforo + adubo verde; $\mathrm{PCa}=$ fosforo + calcário; $\mathrm{PCaAv}=$ fósforo + calcário + adubo verde. 
0 sinal do $\Delta p H$ corresponde ao sinal da carga eletrica dos colóides do solo. Se é negativo, o sistema apresenta balanço negativo de cargas e a carga liquida é negativa e vice-versa (SANCHEZ, 1976). A diminuição da carga liquida negativa do solo está relacionada, principalmente, com o menor teor de matéria orgânica das camadas subsuperficiais (20 - 40 e 40 - $60 \mathrm{~cm})$ em comparação com a camada de $0-20 \mathrm{~cm}$ (tabela 3). Essa relação entre o conteưdo de matéria orgånica e a carga liquida negativa do solo está claramente demonstrada en diversos trabalhos (RAIJ \& PEECH, 1972; MORAIS et al., 1976; SIQUEIRA et al., 1990) e demonstra a importância daquele no componente no desenvolvimento das cargas negativas nos solos tropicais de carga variável.

A carga l1quida negativa estimada aumentou com a elevação do pH do solo de seu valor natural para 6,5 e, inversamente, diminuiu com a reduçăo para 4,5 (tabela 5). Essa variaçăo demonstra a dependência da CTC do solo em relação ao $\mathrm{pH}$.

Ainda na tabela 5, comparando-se a testemunha (T) com os demais tratamentos ao pH natural, observa-se que na camada de $0-20 \mathrm{~cm}$ a adubaçăo fosfatada (tratamentos $P$ e PAv) e a adubação fosfatada + calagem (tratamentos PCa e PCaAv) causaram aumentos entre 0,3 e 0,5 meq/100g na carga liquida negativa do solo. Embora pequenos em termos absolutos, estes números representam aumentos de cerca de 
100\% em relação à testemunha, cuja carga liquida negativa era de 0,4 meq/100g de solo. Resultados semelhantes foram obtidos por SMYTH \& SANCHEZ (1980) com solo semelhante, em trabalho de casa de vegetação e laboratório. Os autores verificaram que a associação da adubação fosfatada e da calagem causou aumentos da carga liquida negativa superiores aos obtidos com cada tratamento, isoladamente. A mesma tendencia foi observada neste trabalho. A media dos tratamentos que associaram adubação fosfatada e calagem (PCa e PCaAv) foi de 0,9 meq/100g de solo, contra 0,75 meq/100g nos tratamentos apenas com adubação fosfatada. Deve-se ressaltar que SMYTH \& SANCHEZ (1980) utilizaram doses altas de fósforo (entre 350 e 540 ppm), aplicadas ao solo de uma só vez, e o período de incubação do solo com o fosfato foi de seis meses. No presente trabalho a P, num total de 334 ppm, foi aplicado no campo em doses de aproximadamente 20 ppm a cada cultivo (considerando-se a incorporação a 20 cm de profundidade), ao longo de seis anos. Os resultados indicam que existiu um efeito residual dos tratamentos com adubação fosfatada e com adubação fosfatada + calagem sobre a carga liquida negativa do solo.

A comparação da carga líquida negativa entre os tratamentos $\mathrm{P}$ e PAv $(0,7$ e 0,8 meq/100g, respectivamente), e PCa e PCaAv (0,7 meq/100g, em ambos) indica que a adubação verde não afetou esse parametro, ou seu efeito foi mascarado pelos tratamentos con fosfato e fosfato + calcário. Por 
outro lado, como os restos de cada cultivo foram sempre incorporados ao solo em todos os tratamentos, inclusive naqueles em que foi aplicada a adubação verde, pode-se supor que os efeitos desses residuos foram equivalentes aos da adubação verde, ou mascararam os efeitos dela.

4.1.2. Capacidade de troca de cátions (CTC) e de ânions (CTA)

A CTC e a CTA ao pH natural do solo e a CTC ao pH 7.0 das amostras para os diversos tratamentos são mostradas na tabela 7 .

Na camada de $0-20 \mathrm{~cm}$ a CTC do solo ao $\mathrm{pH}$ natural aumentou nos tratamentos com calagem e adubação fosfatada, passando de 4,5 meq/100g na testemunha (T), para 5,6 e 5,5 meq/100g nos tratamentos PCa e PCaAv, respectivamente. A predominancia de cargas dependentes de $\mathrm{pH}$ nesse solo, como nos oxissolos em geral, permite que sua CTC seja aumentada pela calagem da maneira aqui verificada (SANCHEZ, 1976). O aumento observado, de cerca de 1 meq/100g de solo deu-se com um aumento de aproximadamente 0,5 unidade de pH (tabela 3).

A adubação fosfatada, isoladamente, mostrou pequena tendencia de aumentar a CTC a $\mathrm{pH}$ natural, como pode-se ver pela comparação da testemunha (cTC = 4,5 meq/100g) com os tratamentos P e PAv (CTC 4,8 e 4,6 meq/100g, 
Tabela 7 - Valores de CTC ao pH natural (CTC nat), CTC ao pH 7,0 (CTC 7) e CTA nat ao pH natural (CTA nat) de um latossolo vermelho-escuro submetido a tratamentos com fósforo, calcário e adubo verde.

\begin{tabular}{llll}
\hline Tratamentos & CTC nat. & CTC 7 & CTA nat.
\end{tabular}

meq/100g

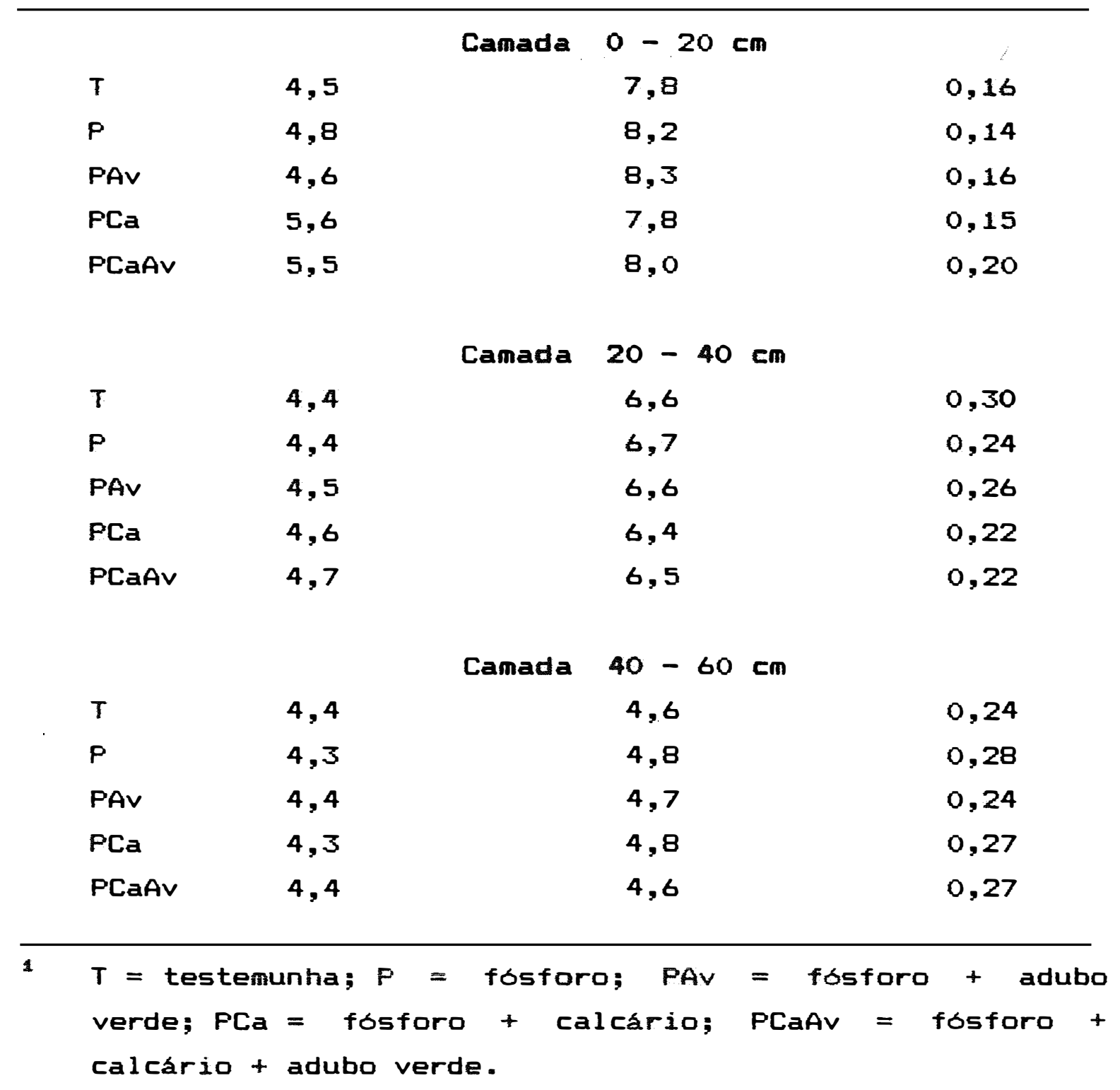


respectivamente). Tal resultado era esperado, em razão da quantidade total de $P$ aplicada ao solo ter sido relativamente pequena (334 ppm). Embora se saiba que a adsorçăo espec1 fica do fosfato aplicado a solos oxidicos aumenta sua carga negativa (CTC), somente doses altas, e geralmente antieconômicas, de P provocam alteraçơses significativas na quantidade dessas cargas, como se constata em resultados relatados na literatura (MEKARU \& UEHARA, 1972; GILLMAN \& FoX, 1980; SMYTH \& SANCHEZ, 1980; NAIDU et a $1 ., 1990$ a).

Na camada de 20 - 40 cm ainda parece ter havido pequeno efeito da calagem sobre a CTC (tabela 7), pois os valores desta nos tratamentos PCa (4,6 meq/100g) e PCaAv $(4,7 \mathrm{meq} / 100 \mathrm{~g})$ foram ligeiramente superiores aos dos outros tratamentos $(4,4$ e 4,5 meq/100g). Possivelmente, o calcário foi incorporado em profundidade pouco maior do que $20 \mathrm{~cm}$, devido as araçós profundas feitas antes de cada cultivo. Com isso, parte da camada de 20 - $40 \mathrm{~cm}$ também sofreu correção, como parece indicar o pH nos tratamentos PCa e PCaAv, ligeiramente mais alto do que nos outros tratamentos (tabela 3). Na camada de $40-60 \mathrm{~cm}$ a CTC a pH natural praticamente năo variou, ficando entre 4,3 e 4,4 meq/100g de solo. Este é um fato que merece destaque pois o manejo, como feito, não influencia a CTC dessa camada, e se se quiser que isto aconteça, outras alternativas devem ser utilizadas.

A CTC ao $\mathrm{pH} 7,0$ năo parece ter sido afetada pelos tratamentos. Na camada de $0-20 \mathrm{~cm}$, a maior 
diferença, registrada entre a testemunha (CTC $=7,8$ meq/100g) e o tratamento PAv (CTC $=8,3$ meq/100g) foi de 0,5 meq/100g. Essa diferença pode ser atribuida ao erro experimental, considerando-se, por exemplo que o tratamento PCa $(7,8$ meq/100g) não diferiu da testemunha. Nas demais camadas praticamente não houve diferença entre os tratamentos. Sabe-se que a aplicação de fosfato aumenta a CTC do solo a pH 7,0, pois a adsorção especifica deste ânion desloca o PCZ para valores mais baixos de $\mathrm{pH}$, o que resulta em aumento correspondente na carga liquida negativa dos colóides do solo, e conseqüentemente em aumento da CTC (MEKARU \& UEHARA, 1972; WANN \& UEHARA, 1978; GILLMAN \& FOX, 1980; LAVERDIERE, 1982). Alén disso, o efeito do fosfato sobre a CTC E acentuado pela calagem (SMYTH \& SANCHEZ, 1980). A auséncia de efeito da adubação fosfatada, no presente caso, provavelmente se deve à baixa dose utilizada e ao parcelamento da aplicação do $P(334$ ppm, divididos em dezessete doses iguais, aplicadas ao longo de seis anos). Como já foi comentado em capitulos anteriores, somente doses altas de fósforo, aplicadas de uma só vez, parecem ser capazes de alterar significativamente o PCZ, e, por conseqüencia, a CTC de solos de carga variável. Nas demais camadas, os valores da CTC podem ser considerados praticamente iguais, pois as diferenças entre os tratamentos foram ainda menores do que na camada de 0 - $20 \mathrm{~cm}$ (tabela b). Por outro lado, a CTC ao pH 7,0 diminuiu com a profundidade, 
passando de 7,8 meq/100g na testemunha, na camada de $0-20$ $\mathrm{cm}$, para 6,6 e 4,6 meq/100g nas camadas de 20 - 40 e 40 - 60 cm, respectivamente, no mesmo tratamento. Essa diminuição deve ser atribulda à redução do teor de matêria orgânica do solo com a profundidade (tabela 3).

A capacidade de troca de ánions (CTA) ao pH natural do solo variou entre $0,14 \mathrm{meq} / 100 \mathrm{~g}$, no tratamento $P$ na camada de $0-20 \mathrm{~cm}$, e $0,30 \mathrm{meq} / 100 \mathrm{~g}$, na testemunha (T), na camada de 20 - $40 \mathrm{~cm}$ (tabela 7). Tais valores são comparáveis aos obtidos por SMYTH \& SANCHEZ (1980) para um solo semelhante, coletado na regiăo de Brasilia (DF). Os baixos valores de CTA dificultam a comparação entre os tratamentos. Embora grandes em termos relativos, as diferenças são pequenas em termos absolutos, $e$, possivelmente, não refletem diferenças reais entre tratamentos. As dificuldades inerentes ao método de determinação da CTA, provavelmente induzem a considerável margem de erro para valores baixos desse parámetro. Assim, considera-se que os tratamentos praticamente não afetaram a CTA, que ficou entre 0,14 e 0,20 , entre 0,22 e entre 0,30 e 0,24 e 0,28 meq/100g de solo nas camadas de $0-20,20-40$ e 40 - $60 \mathrm{~cm}$, respectivamente. 
4.2. Efeito dos tratamentos sobre a capacidade de adsorçăo de fosfato, sulfato e nitrato

4.2.1. Adsorçáo de fósfore

As isotermas de adsorção de fósforo obtidas através da equação de Freundlich são mostradas na figura 4. Us valores dos paråmetros das equaçôes de cada curva estão na tabela 8. 


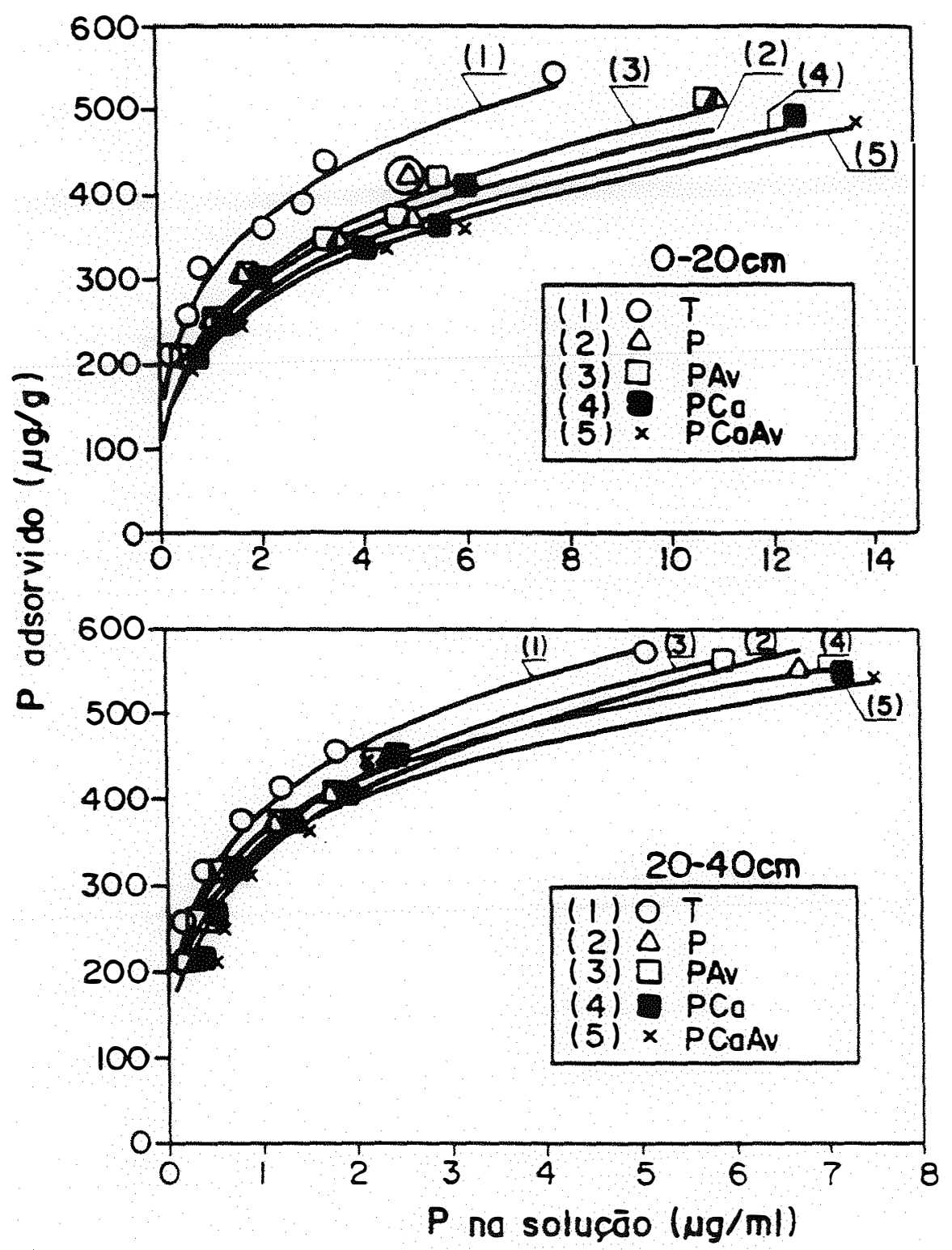

Figura 4 - Isotermas de adsorção de fósforo do latossolo vermelho-escuro nos diversos tratamentos, obtidas atraves da equação de Freundlich. ( $T$ = testemunha; $P=$ fosforo; $P A V=$ fósforo + adubo verde; $\mathrm{PCa}=$ fósforo + calcário; PCaAv = fósforo + + calcário + adubo verdel. 0 ponto marcado com cĺrculo năo foi incluido no cálculo da regressão. 
Tabela 8 - Parametros das equaçôs de regressão ajustadas às isotermas de adsorção de fósforo das amostras do latossolo vermelino-escuro, segundo o modelo de Freundich.

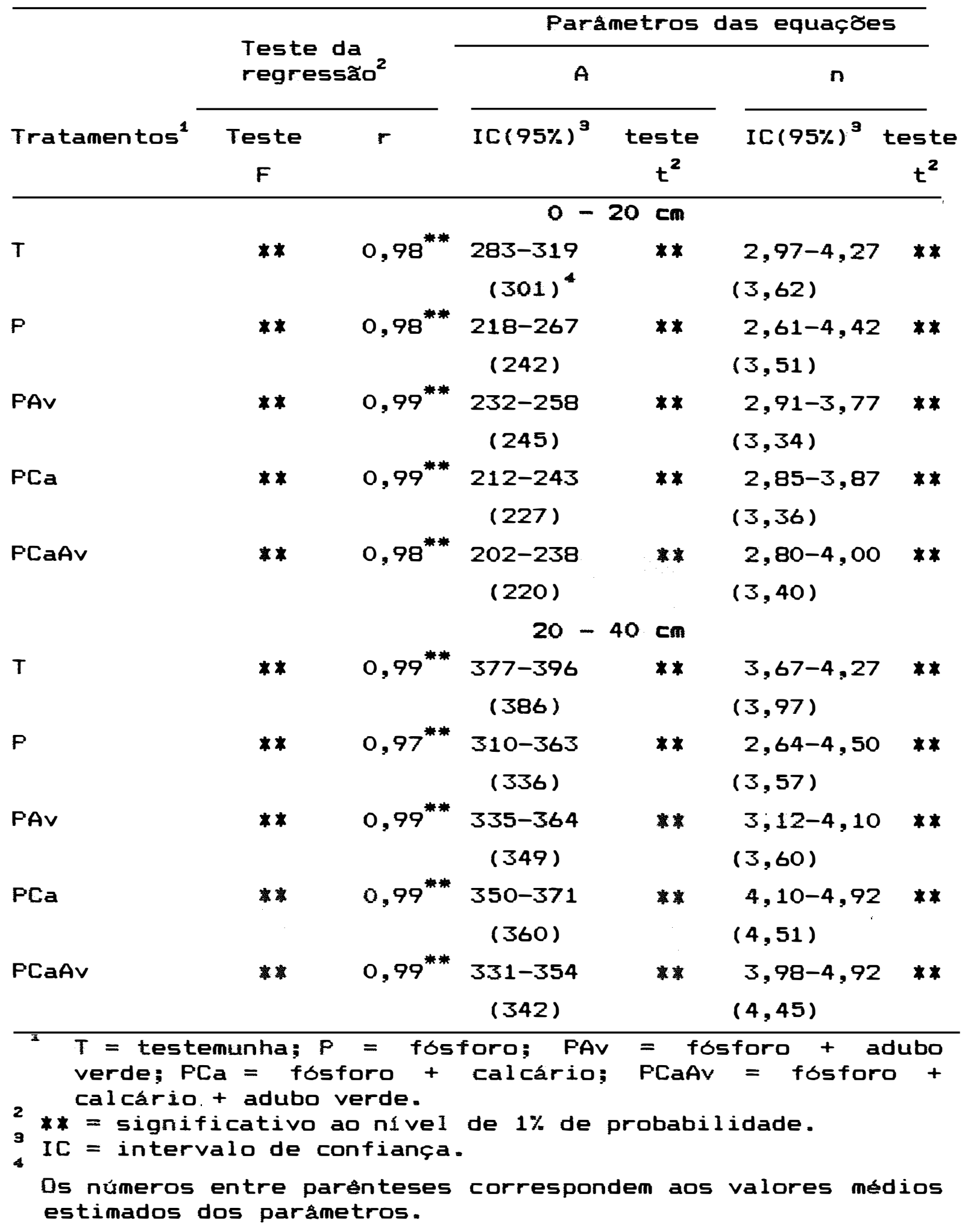


A equação descreveu adequadamente 0 comportamento dos dados experimentais, como se constata pela alta significância $(p<0,01)$ do teste $F$ para as regressões e pelos valores dos coeficientes de correlação obtidos.

Os gráficos da figura 4 e os dados da tabela 8 mostram que a adsorção do fósforo aumentou com a profundidade. No caso da figura, isso pode ser constatado pela comparação visual das curvas do tratamento testemunha (T) nas duas camadas de solo. Pela tabela 8, por sua vez, nota-se que o valor de A na camada de $0-20 \mathrm{~cm}$ (301) foi inferior ao valor do mesmo parametro na camada de 20 - 40 cm (386). Por outro lado, o valor de $n$ na camada de 20 - 40 cm (3,97), embora ligeiramente maior, não diferiu significativamente $(p<0,05)$ do valor na camada de $0-20 \mathrm{~cm}$ $(3,62)$. Isso indica que, embora a capacidade de retenção de fósforo do solo tenha aumentado em profundidade, a energia de ligação entre o fósforo e as particulas do solo permaneceu praticamente constante, nas camadas de $0-20$ e $20-40$ cm. A diferença entre as duas camadas quanto à adsorção é atribulda principalmente à diminuição da matêria orgânica em profundidade (tabela 3), pois sabe-se que maior teor de matéria orgânica contribui para reduzir a capacidade de adsorção de fósforo (FOX \& KAMPRATH, 1970; MOSHI et al., 1974; FASSBENDER, 1969; LEAL \& VELLOSO, 1973; OWUSU-BENNOAH \& ACEUAYE, 1989). A possibilidade de ânions orgânicos competirem com o fosfato pelos sitios de adsorção já foi 
demonstrada em diversos trabalhos (NAGARAJAH et al., 1970; LOPEZ-HERNANDEZ et al.; 1979; KAFKAFI et al., 1988; EASTERWODD \& SARTAIN, 1990).

A comparação das curvas de adsorção da figura 4 mostra que os tratamentos reduziram a capacidade de adsorção de fósforo do solo. Os efeitos foram mais acentuados na camada de $0-20 \mathrm{~cm}$, onde os tratamentos foram realizados. 0 pequeno efeito dos tratamentos, ainda observado na camada de 20 - $40 \mathrm{~cm}$, provavelmente, deve-se ao fato de terem sido incorporados, em profundidade ligeiramente superior a $20 \mathrm{~cm}$, como se comentou anteriormente. Apesar da separação das curvas de adsorção, principalmente na camada de $0-20 \mathrm{~cm}$, tanto nesta quanto na de $20-40 \mathrm{~cm}$, os tratamentos F, PAv, PCa e PCaAv não diferiram entre si $(p<0,05)$ quanto à adsorção máxima de fósforo, representada pelo parámetro $A$ da equação de Freundlich, ou quanto à energia de ligação entre o fósforo e as particulas do solo, representada pelo parâmetro n da mesma equação. Os valores desses paråmetros para os citados tratamentos (tabela 8) são estatisticamente iguais, uma vez que os intervalos de confiança (IC 95\%) calculados para os mesmos apresentam sobreposição. A aplicação de fosfato e de fosfato + calcário reduziu a capacidade máxima de adsorção de fósforo do solo, mas não modificou significativamente a energia de ligação entre o fósforo e 0 solo. Na tabela 8 , vê-se que os valores de A nos tratamentos P, PAv, PCa e PCaAv nas camadas de 0 - 
$20 \mathrm{~cm}(220$ a 245) e $20-40 \mathrm{~cm}$ (336 a 360) foram menores $(p<0,05)$ do que os da testemunha nas mesmas camadas (301 e 386, respectivamente), $e$ que os valores de $n$ foram semelhantes. Os resultados obtidos mostram que os efeitos da adubação fosfatada 1334 ppm de $P$, distribuidos em partes iguais em dezessete cultivos, ao longo de seis anos) foram equivalentes aos da associação adubaçăo fosfatada + calagem $(2,5$ e $3,0 \mathrm{t} / \mathrm{ha}$ de calcário aplicadas no primeiro, e entre o nono e o décimo cultivos, respectivamente).

O fato da adubação fosfatada e da calagem reduzirem a capacidade de adsorção de fósforo já havia sido observado por SMYTH \& SANCHEZ (1980) em experimento de casa de vegetação, com solo semelhante.Resultados parecidos, também referentes aos efeitos de curto prazo desses tratamentos, foram obtidos por outros autores (HAYNES, 1983; NAIDU et al., 1990b), com outros solos. A redução da adsorção de fósforo é atribuida ao aumento da repulsão eletrostática do ánion devido ao aumento da eletronegatividade dos colóides do solo, causado tanto pela calagem (BOWDEN et al., 1980; SMYTH \& SANCHEZ, 1980; HAYNES, 1983) quanto pela adubação fosfatada (MULJADI et al., 1966; SMYTH \& SANCHEZ, 1980; HAYNES, 1983). Com base no PCZ e no pH natural das amostras, fez-se uma estimativa do potencial eletrico da superficie dos colóides do solo, usando-se a equação de Nernst, adaptada por RAIJ \& PEECH (1972): wo (mV) $=59(\mathrm{PCZ}-\mathrm{pH})$. Os resultados (tabela 9) indicam que os 
tratamentos com fosfato e calcário aumentaram o potencial elétrico negativo do solo (o que é coerente com o aumento da carga liquida negativa das amostras, como apresentado na tabela 5), o que deve ter afetado negativamente a adsorçăo do fósforo. Além do aumento da repulsão eletrostática deve-se considerar ainda que a redução da adsorção de fósforo pode ter sido causada pelo bloqueio de parte dos sitios de adsorção por ions fosfato (BARROW, 1974).

Tabela 9 - Variação do potencial elétrico ( $\left.\psi_{0}\right)$ estimado dos coloides do latossolo vermelho-escuro, nos diversos tratamentos.

Tratamentos ${ }^{1}$

Camada

$T$

P

PAV

PCa

PCaAv

\begin{tabular}{llcccc}
\hline $0-20 \mathrm{~cm}$ & -94 & -112 & -124 & -136 & -136 \\
$20-40 \mathrm{~cm}$ & -83 & -88 & -83 & -100 & -112 \\
$40-60 \mathrm{~cm}$ & -41 & -47 & -65 & -65 & -71 \\
\hline
\end{tabular}

$1 T=$ testemunha; $P=$ fosforo; $P A V=$ fosforo + adubo verde; $\mathrm{PCa}=$ fósforo + calcárioj PCaAv = fósforo + calcário + adubo verde. 
Trabalhando com solos da Austrália, incubados com fosfato em laboratório ou adubados a campo com fosfato, tres anos antes dos testes de adsorção (BARROW, 1974), verificou que a adiçăo prévia de fosfato modificou a posição e reduziu a declividade das curvas de adsorção de fósforo dos solos testados. Os resultados indicaram que parte do fosfato adicionado havia se convertido a formas que bloqueavam sitios de adsorção, impedindo sua reação com lons fosfato adicionados posteriormente, e, desse modo, diminuindo o poder tampão de fósforo dos solos. Para as baixas doses de fósforo geralmente aplicadas a cada cultivo nas propriedades agricolas, o efeito da adubação fosfatada sobre o poder tampão de fósforo (PTP) do solo deve ser pequeno. Segundo BARROW (1974) sob tais condiçశes pode-se esperar que o PTP do solo permaneça constante por vários anos. Us resultados do presente trabalho confirmam tal observação, pois a PTP do solo estudado, estimado pela diferença na quantidade de $P$ adsorvido pelo solo entre as concentraç̧es de 0,25 e 0,35 ppm de P na solução, calculado conforme OZANNE \& SHAW (1968), praticamente não se alterou com a adubação fosfatada, que foi aplicada em pequenas doses ao longo dos dezessete cultivos. Isto pode ser constatado comparando-se a valor do PTP calculado para os diversos tratamentos na camada de 0 - $20 \mathrm{~cm}$ (PTP $=20,16,17,16$ e 16 nos tratamentos T, P, PAv, PCa e PCaAv, respectivamente).

A capacidade de adsorção de fósforo do solo 
não foi afetada pela adubação verde, pois, como se viu, os tratamentos P e FAv e FCa e PCaAv não diferiram entre si. A incorporação dos residuos das culturas nas parcelas de todos os tratamentos, inclusive naqueles que receberam adubação verde, e os efeitos dos tratamentos com fosfato e fosfato + calcário podem ter mascarado os efeitos da incorporação do guandu (16 t/ha). No entanto, parece mais provável que a adubação verde não tenha, efetivamente, alterado os parametros de adsorção de fósforo, como indicam resultados obtidos por LE MARE et al. (1987) com solo semelhante.Trabalhando em laboratório com amostras de um latossolo vermelho-escuro da região de Brasilia, o qual havia recebido, ao longo de oito anos, adubaçăo verde com cerca de 16 tha de matéria seca de crotalária (Crotalaria juncea) + mucuna (Stylozobium atterinum), esses autores constataram que - tratamento não havia afetado a capacidade de adsorção de fósforo do solo. Note-se que a quantidade de matéria seca incorporada ao solo foi igual a usada no presente trabalho (tabela 1).

\subsubsection{Adsorçáa de sulfato}

A capacidade de adsorção de sulfato das amostras de solo foi avaliada através do método das isotermas de adsorção, de maneira análoga à do fósforo. Em vista da maior mobilidade do sulfato, avaliou-se sua adsorção nas tres camadas de solo estudadas $(0-20,20-40$ e $40-60 \mathrm{~cm})$. As 
curvas obtidas através da equaçăo de Freundlich são mostradas nas figuras 5 a 7 .

As isotermas de adsorção do sulfato foram adequadamente descritas pela equação de Freundlich, como se pode ver pela alta significância do teste $F$ para as regressðes, e pelos elevados e significativos coeficientes de correlação obtidos (tabela 10). 


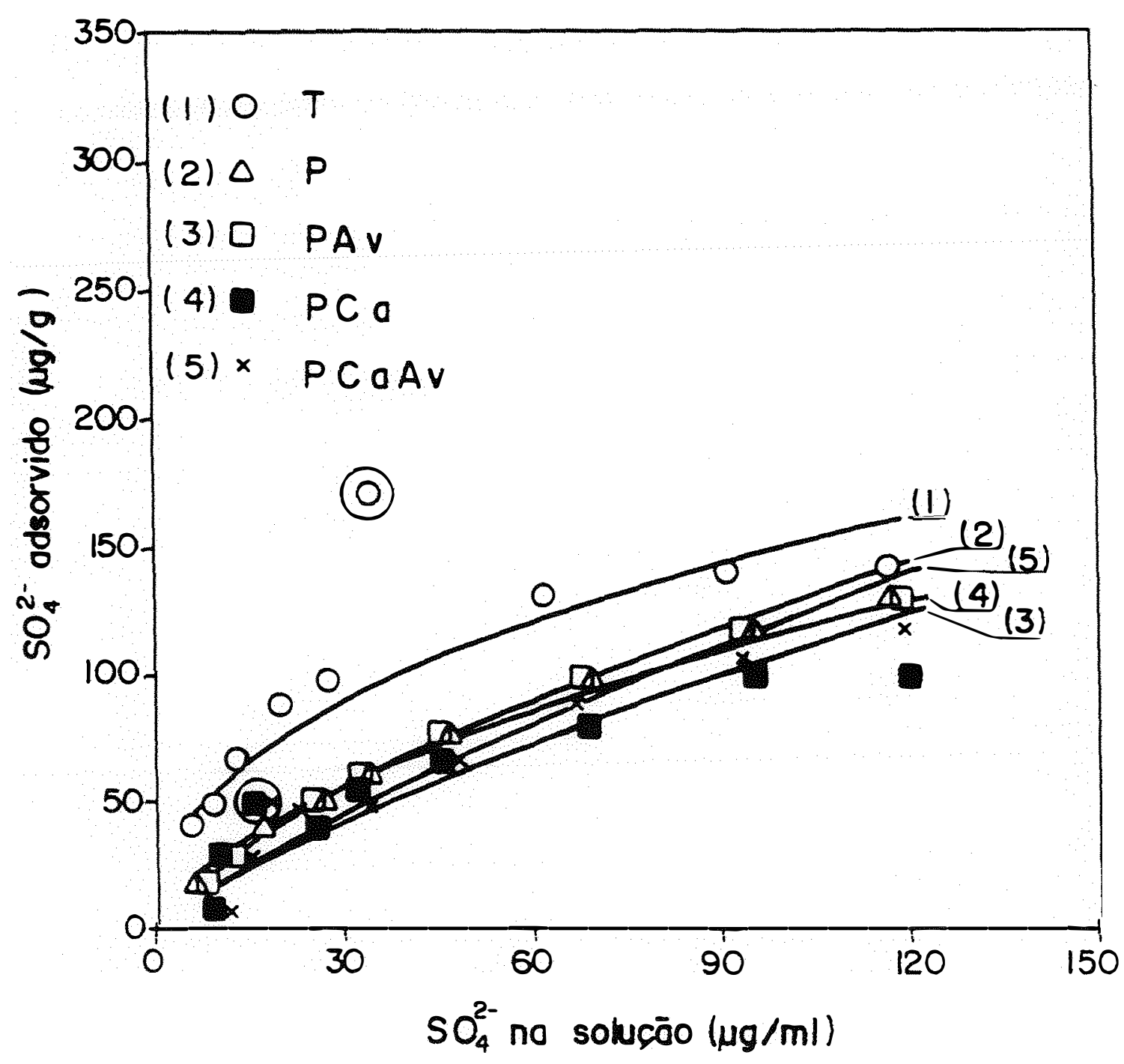

Figura 5 - Isotermas de adsorção de sulfato do latossolo vermelho-escuro nos diversos tratamentos na camada de $0-20 \mathrm{~cm}$, obtidas atraves da equaçăo de Freundlich. $T=$ testemuntia; $P=$ fosforo; $P A V=$ fosforo + adubo verde; $\mathrm{PCa}=$ fósforo + calcário; PCaAv = fosforo + calcário + adubo verde. Os pontos marcados com círculo nă foram incluidos no cálculo das regressães. 


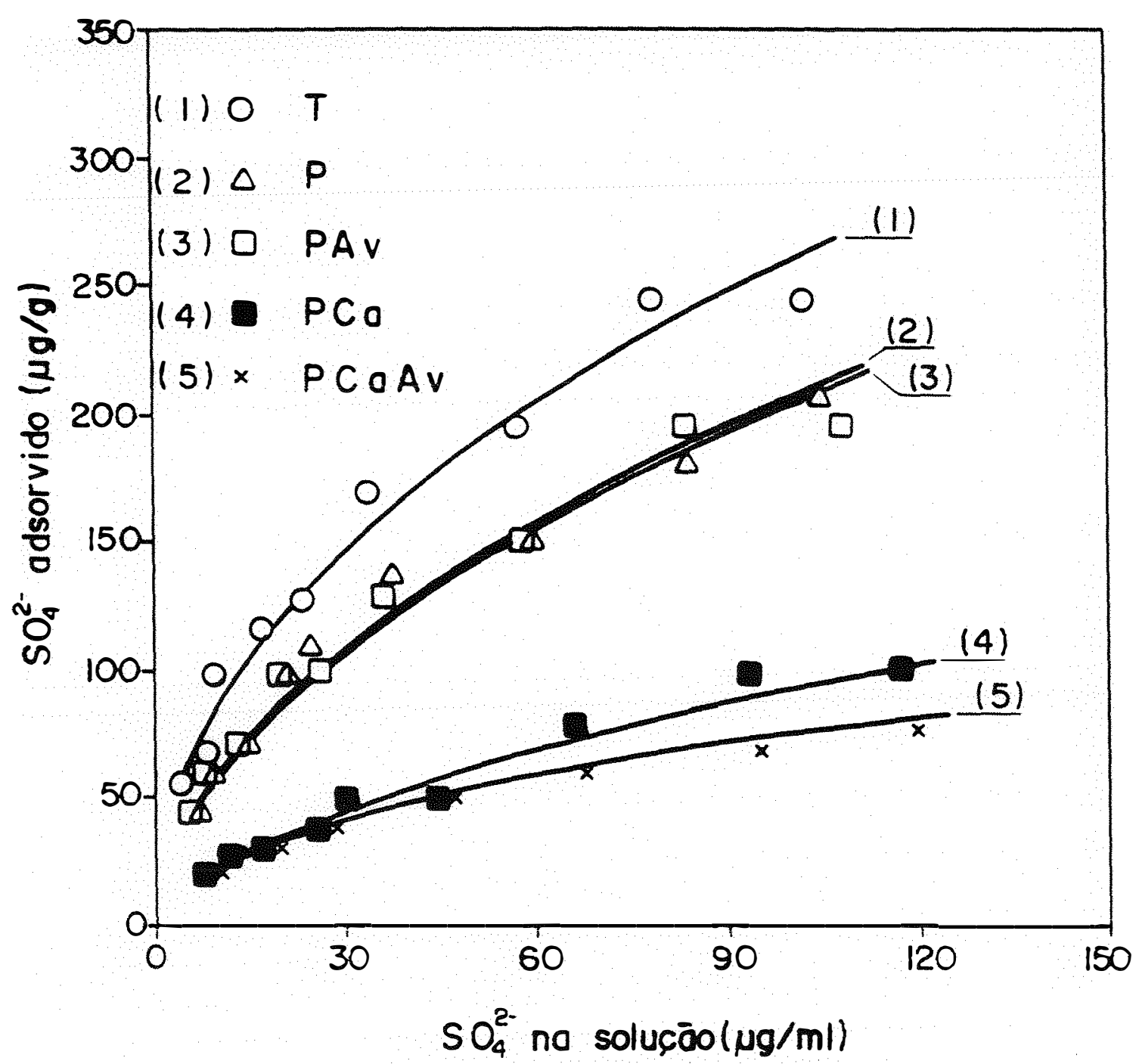
Figura 6 - Isotermas de adsorção de sulfato do latossolo vermelho-escuro nos diversos tratamentos na camada de $20-40 \mathrm{~cm}$ obtidas atravess da equaçăo de Freundlich. $T=$ testemunha: $P=$ fosfur $0 ; P A V=$ fosforo + adubo verde; PCa = fósforo + calcário; PCaAv = fósforo + calcário + adubo verde.




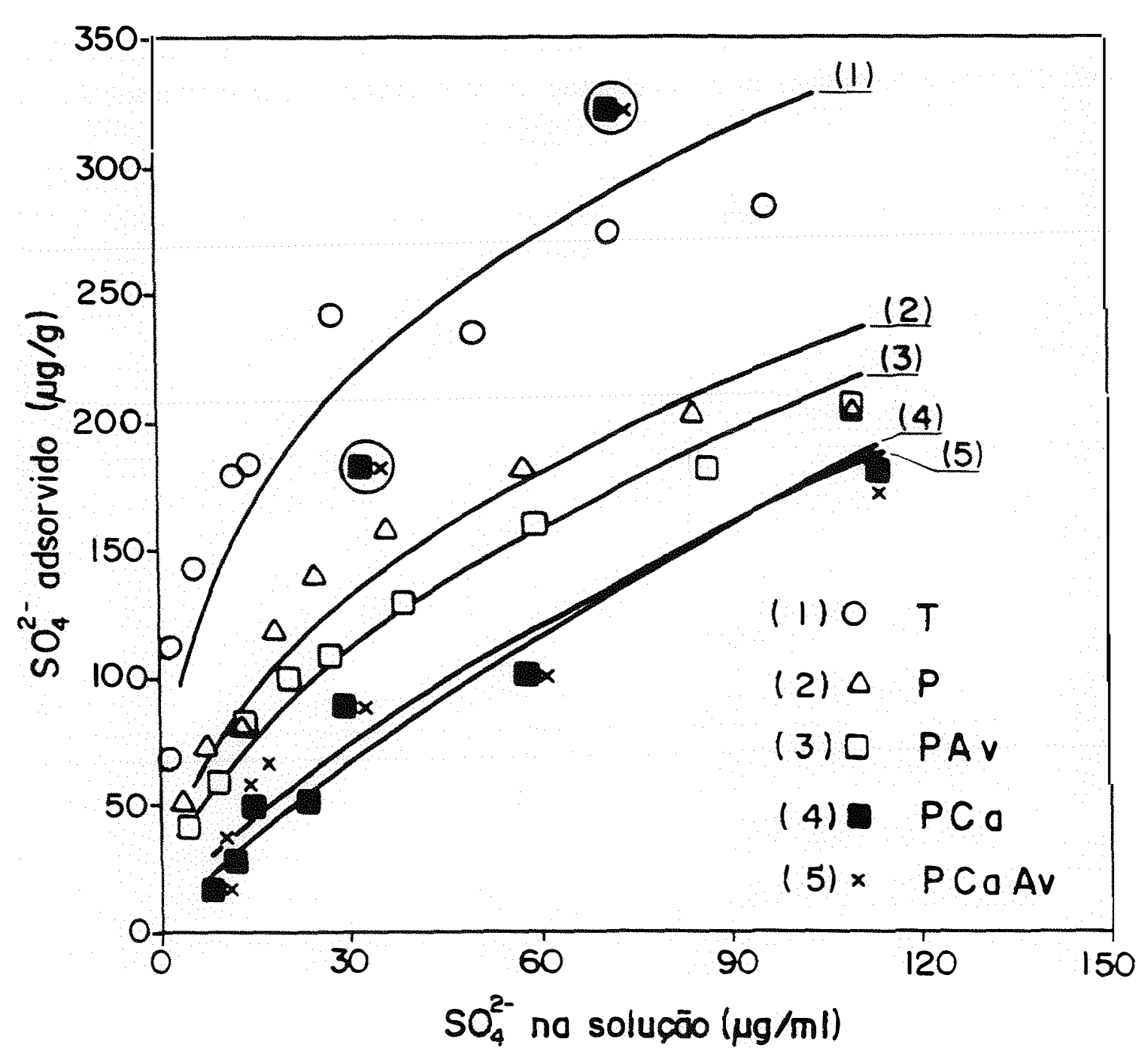

Figura 7 - Isotermas de adsorção de sulfato do latossolo vermel ho-escuro nos diversos tratamentos na camada de $40-60 \mathrm{~cm}$, obtidas através da equaçăo de Freundlich. $T=$ testemunha; $P=$ fóforo; $P A V=$ fósforo + adubo verde; $\mathrm{PCa}=$ fósforo + calcário; PCaAv = fósforo + calcário + adubo verde. Os pontos marcados com circulo nå foram incluidos no cálculo das regressáes. 
Tabela 10 - Paråmetros das equaçóes de regressão ajustadas as isotermas de adsorçao de sulfato das amostras do latossolo vermel ho-escuro, segundo o modelo de Freundlich.

\begin{tabular}{|c|c|c|c|c|c|c|}
\hline \multirow[b]{3}{*}{ Tratamentos ${ }^{1}$} & \multirow{2}{*}{\multicolumn{2}{|c|}{$\begin{array}{l}\text { Teste da } \\
\text { regressao }\end{array}$}} & \multicolumn{4}{|c|}{ Parâmetros das equaçбes } \\
\hline & & & \multicolumn{2}{|l|}{$A$} & \multicolumn{2}{|l|}{$n$} \\
\hline & $\begin{array}{l}\text { Teste } \\
\text { F }\end{array}$ & $\mathbf{r}$ & $I C(95 \%)^{3} t$ & $\begin{array}{c}\text { teste } \\
t^{2}\end{array}$ & $\operatorname{IC}(95 \%)^{3}$ & $\begin{array}{c}\text { teste } \\
t^{2}\end{array}$ \\
\hline \multicolumn{7}{|c|}{$0-20 \mathrm{~cm}$} \\
\hline $\mathbf{T}$ & ** & $0,96^{* *}$ & $\begin{array}{r}14,2-30,8 \\
(21,0)^{4}\end{array}$ & ** & $\begin{array}{c}1,85-3,15 \\
(2,32)\end{array}$ & ** \\
\hline $\mathbf{P}$ & $* *$ & $0,99^{* *}$ & $\begin{array}{r}4,2-6,7 \\
(5,3)\end{array}$ & ** & $\begin{array}{c}1,32-1,60 \\
(1,45)\end{array}$ & $* *$ \\
\hline PAV & $\star *$ & $0,95^{* *}$ & $\begin{array}{r}5,2-9,5 \\
(7,0)\end{array}$ & $\star *$ & $\begin{array}{c}1,30-2,23 \\
(1,64)\end{array}$ & $* *$ \\
\hline PCa & $\star \star *$ & $0,93^{* *}$ & $\begin{array}{r}1,0-9,6 \\
(3,1)\end{array}$ & $\star$ & $\begin{array}{c}0,93-2,14 \\
(1,30)\end{array}$ & $\star *$ \\
\hline PCaAv & ** & $0,94^{* *}$ & $\begin{array}{r}0,1-7,7 \\
(2,7)\end{array}$ & NS & $\begin{array}{c}0,90-1,84 \\
(1,20)\end{array}$ & ** \\
\hline & & & $20-4$ & $40 \mathrm{~cm}$ & & \\
\hline$T$ & $\star *$ & $0,99^{* *}$ & $\begin{array}{c}25,0-36,5 \\
(30,2)\end{array}$ & $\star *$ & $\begin{array}{c}1,91-2,25 \\
(2,12)\end{array}$ & $* *$ \\
\hline$P$ & ** & $0,98^{* *}$ & $\begin{array}{c}13,4-23,5 \\
(17,8)\end{array}$ & ** & $\begin{array}{c}1,63-2,21 \\
(1,88)\end{array}$ & ** \\
\hline PAV & $\star *$ & $0,98^{* *}$ & $\begin{array}{c}13,3-22,3 \\
(17,2)\end{array}$ & ** & $\begin{array}{c}1,63-2,16 \\
(1,85)\end{array}$ & ** \\
\hline $\mathrm{PCa}$ & ** & $0,98^{* *}$ & $\begin{array}{c}4,1-8,3 \\
(5,9)\end{array}$ & $* *$ & $\begin{array}{c}1,43-2,00 \\
(1,67)\end{array}$ & ** \\
\hline PCaAv & ** & $0,97^{* *}$ & $\begin{array}{c}5,9-11,5 \\
(8,2)\end{array}$ & ** & $\begin{array}{c}1,75-2,58 \\
(2,08)\end{array}$ & ** \\
\hline
\end{tabular}


Tabela 10 - Paråmetros das equaçס̋s de regressão ajustadas às isotermas de adsorção de sulfato das amostras do latossolo vermelho-escuro, segundo a modelo de Freundlich (continuaçå).

\begin{tabular}{|c|c|c|c|c|c|c|}
\hline \multirow{3}{*}{ Tratamentos 1} & \multirow{2}{*}{\multicolumn{2}{|c|}{$\begin{array}{l}\text { Teste da } \\
\text { regressã }\end{array}$}} & \multicolumn{4}{|c|}{ Parametros das equaçชes } \\
\hline & & & \multicolumn{2}{|l|}{ A } & \multicolumn{2}{|l|}{ n } \\
\hline & $\begin{array}{c}\text { Teste } \\
F\end{array}$ & $r$ & $\operatorname{IC}(95 \%)^{9}$ & $t^{2}$ & $\operatorname{IC}(95 \%)^{9}$ & $\begin{array}{r}\text { teste } \\
t^{2}\end{array}$ \\
\hline & \multicolumn{6}{|c|}{$40-60 \mathrm{~cm}$} \\
\hline $\mathbf{T}$ & ** & $0,93^{* *}$ & $\begin{array}{c}46,1-96,2 \\
(65,7)\end{array}$ & $\star *$ & $\begin{array}{c}2,21-4,54 \\
(2,86)\end{array}$ & $* *$ \\
\hline $\mathbf{P}$ & $\star \star$ & $0,96^{* *}$ & $\begin{array}{c}19,1-39,4 \\
(27,5)\end{array}$ & $\star *$ & $\begin{array}{c}1,78-2,86 \\
(2,17)\end{array}$ & $\star *$ \\
\hline PAV & $\star \star$ & $0,98^{* *}$ & $\begin{array}{c}14,4-25,7 \\
(19,3)\end{array}$ & $\star *$ & $\begin{array}{c}1,68-2,33 \\
(1,96)\end{array}$ & $\star *$ \\
\hline PCa & $\star *$ & $0,96^{* *}$ & $\begin{array}{c}2,0-10,2 \\
(4,6)\end{array}$ & $\star *$ & $\begin{array}{c}0,97-1,84 \\
(1,26)\end{array}$ & ** \\
\hline PCaAv & ** & $0,93^{* *}$ & $\begin{array}{c}2,7-18,9 \\
(7,2)\end{array}$ & $\star *$ & $\begin{array}{c}1,03-2,53 \\
(1,47)\end{array}$ & ** \\
\hline
\end{tabular}

$T=$ testemunha; $P=$ fosforo; $P A V=$ fosforo + adubo verdes $\mathrm{PCa}=$ fósforo + calcário: PCaAv = fósforo + calcário + adubo verde.

2*, *, NS = significativo a $1 \%$, a $5 \%$, e nă significativo a 5\% de probabilidade, respectivamente.

IC = intervalo de confiança.

Ds números entre parenteses correspondem aos valores médios estimados dos parametros.

A posição das curvas dos tratamentos em relaçăo à da testemunha (figuras 5 a 7 ) indica que eles reduziram a adsorção de sulfato pelo solo nas tres camadas estudadas. Na camada de 0 - $20 \mathrm{~cm}$ as curvas estå proximas 
umas das outras. Já nas camadas de 20 - 40 e $40-60 \mathrm{~cm}$, é clara a separação entre as curvas desses tratamentos. Em ambas as camadas as curvas dos tratamentos PCa e PCaAv estão mais deslocadas para baixo do que as curvas dos tratamentos $P$ e PAv, evidenciando que a associação da calagem com a adubação fosfatada foi mais efetiva na redução da adsorção do sulfato do que a adubação fosfatada, isoladamente. Essa diferença entre os tratamentos é refletida pela diferença entre os valores dos parâmetros das equaçôes de regressão mostrados na tabela 10, os quais representam as curvas de adsorção das figuras 5 a 7 .

A calagem diminui a adsorção do sulfato devido ao aumento da carga negativa das particulas do solo causado pela elevação do pH (MARSH et al., 1987; BOLAN et al., 1988), - que aumenta a repulsão do anion. A aplicação de fosfato também reduz a adsorção do sulfato, por efeito de competição pelos sitios de adsorção ou pelo aumento da carga negativa dos colóides (BOLAN et al., 1988). Por outro lado, a combinação desses tratamentos resulta em aumento de carga negativa superior à soma de seus efeitos individuais (SMYTH \& SANCHEZ, 1980). Esse efeito foi observado no presente trabalho, pois a CTC a pH natural do solo (tabela 7), que reflete a quantidade de cargas negativas, e também o potencial elétrico negativo dos colódes (tabela 9) foram maiores nos tratamentos PCa e PCaAv.

Continuando as observaçชes feitas a partir da 
comparação das curvas, constata-se que a adubação fosfatada e a calagem reduziram significativamente a adsorção máxima de sulfato (paråmetro A) pelo solo, em todas as camadas. Na camada de $0-20 \mathrm{~cm}$ os valores de $A$ nos tratamentos $P(5,3)$, PAv $(7,0)$, PCa $(3,1)$ e PCaAv $(2,7)$, embora significativamente menores $(p<0,05)$ que 0 da testemunha $(21,0)$, foram estatisticamente iguais entre si. Já nas camadas subsuperficiais, os tratamentos com adubação fosfatada + calagem causaram reduçăo significativamente maior no valor de $A$ do que os tratamentos apenas com adubação fosfatada (valores de A na camada de $20-40 \mathrm{~cm}: T=30,2, P=17,8$, PAv $=17,2, P C a=5,9$ e PCaAv $=8,2 ;$ valores de $A$ na camada de $40-60 \mathrm{~cm}: T=65,7, P=27,5, \mathrm{PAV}=19,3, \mathrm{PCa}=4,5 \mathrm{e}$ PCaAv $=7,2)$.

o aumento do pH induzido pela calagem, e também a adubação fosfatada, favorecem a dessorção $e$ a lixiviação do sulfato no solo (BOLAN et al., 1988). Por outro lado, a calagem favorece a mineralização da matéria orgânica, o que resulta na produção de ânions orgănicos que podem competir com o sulfato pelos sitios de adsorçăo (CHAO, 1964). Assim, devido ao efeito combinado do aumento da mineralização da matêria orgânica e da dessorção de sulfato da camada de $0-20 \mathrm{~cm}$, anions orgânicos e/ou sulfato. podem ter lixiviado desta para as camadas subjacentes, ocupando sitios de adsorção, e assim reduzido a capacidade de adsorção do sulfato nessas camadas. Uma indicação nesse sentido 
parece ser o maior teor de sulfato extraivel nas amostras dos tratamentos PCa e PCaAv em relação a P e PAv, na camada de 40 - $60 \mathrm{~cm}$ (tabela 3).

A energia de ligaçăo do sulfato ao solo, praticamente nå foi afetada pelos tratamentos (tabela 10). Ao nível de significância de $5 \%$, apenas os tratamentos $P$ e PCaAv, na camada de 0 - 20 cm e PCa, na camada de 40 - 60 cm apresentaram valores de $n$ inferiores ao da testemunha.

0 fato da capacidade de adsorção de sulfato na camada de $0-20 \mathrm{~cm}$, ter sido igual para os tratamentos com adubaçăo fosfatada e com adubaçå fosfatada + calagem nå era esperado, pois os efeitos da calagem sobre as caracteristicas do solo que afetam a adsorçă foram mais acentuados nessa camada. Pode-se citar como exemplo o pH mais elevado (tabela 3), a carga liquida negativa ligeiramente maior (tabela 5) e também o maior potencial eletrico negativo (tabela 9) nos tratamentos com calcário. Tais condiçôes săo antagónicas a adsorçăo, pois implicam em aumento da repulsão elestrostática do anion pelas particulas do solo (COUTO et al., 1979; MARSH et al., 1987; BOLAN et al., 1988). No entanto, năo se pode descartar a hipótese da matéria orgânica ter mascarado os efeitos dos tratamentos.

Ds efeitos da calagem sobre a adsorção de sulfato nas camadas de 20 - 40 e 40 - $60 \mathrm{~cm}$ podem ser atribuidos, em parte, ao pH do solo ligeiramente maior nos tratamentos que incluiram calcario (tabela 3). No entanto, 
as pequenas diferenças de pH, por si so, parecem insuficientes para explicar as diferenças de adsorção observadas. Admite-se como hipótese, que a redução da capacidade de adsorção tenha ocorrido pela ocupação de parte dos sitios de adsorção com sulfato lixiviado da camada arável do solo.

Sabe-se que o aumento do pH do solo pela calagem favorece a dessorção e a lixiviação do sulfato (cHAO et al., 1962; BOLAN et al., 1988; CAMARGO \& RAIJ, 1989), que encontrando condiçőes favoráveis em camadas mais profundas, pode ser novamente adsorvido. Isto parece ter ocorrido na camada de 40 - $60 \mathrm{~cm}$, onde houve aumento nos teores de sulfato extraivel, principalmente nas amostras dos tratamentos que incluíram calagem (tabela 3). Nota-se nessa tabela que os teores de sulfato foram em geral maiores nas camadas de 20 - 40 e 40 - $60 \mathrm{~cm}$, demonstrando a mobilidade do ánion no perfil do solo. Por outro lado, independentemente dos tratamentos, o sulfato sofreu lixiviação da camada de 0 $20 \mathrm{~cm}$ e parte acumulou-se nas camadas inferiores do solo. A adsorça do sulfato lixiviado da superficie, nessas camadas subjacentes que apresentam maior capacidade de adsorça, contribui para manter pelo menos uma fração do mesmo ainda potencialmente disponível, principalmente para culturas com sistema radicular profundo.

Diversos pesquisadores constataram redução da adsorça de sulfato em diferentes tipos de solos incubados 
com calcário e/ou fosfato, en condiçzes de laboratório (CHAO et al., 1962; BORNEMISZA \& LLANOS, 1967; MARSH et al., 1987; BOLAN et al., 1988). Naturalmente as condiçơes experimentais desses trabalhos, em que os tratamentos foram aplicados em doses únicas, e geralmente altas, e os periodos de incubaçăo foram curtos, năo permitiram avaliar a existencia de efeitos cumulativos e de longo prazo dos tratamentos.

Os resultados do presente trabalho confirmam as constataçzes desses pesquisadores. Por outro lado demonstram, adicionalmente, que também sob condiçชes de campo a calagem e a adubaçăo fosfatada (aplicadas em niveis comumente utilizados nas propriedades agricolas) reduzem a capacidade de adsorção de sulfato do solo. Os tratamentos apresentaram um considerável efeito de longo prazo sobre a adsorção do sulfato, pois o calcário $(5,5 \mathrm{t} / \mathrm{ha})$ e o fosfato (334 ppm de P) foram aplicados parceladamente ao solo ao longo de seis anos (entre 1982 e 1989) e as amostras para os testes de adsorção foram coletadas dois anos após (em 1991).

\subsubsection{Adsorçáa de nitrato}

As amostras de solo de todos os tratamentos e camadas estudados apresentaram baixa capacidade de adsorça de nitrato. Uma indicaçăo dessa caracteristica săo as baixas capacidades de troca de anions (CTA), que ficaram entre 0,15 e 0,30 meq/100g de solo (tabela 7). Em virtude disso, năo 
foi possivel estabelecer isotermas de adsorçăo para o nitrato, optando-se pelo método simplificado de BLACK \& WARING (1976) já descrito em Material e Métodos. De acordo com o método, a quantidade de nitrato adsorvido pelas amostras de solo foi considerada como sua capacidade de adsorção de nitrato (tabela 11).

Tabela 11 - Capacidade de adsorção de nitrato do latossolo vermelho-escuro nos tratamentos estudados médias de duas repetições.

Camada ( cm)

Tratamentos

$0-20$

$20-40$

$40-60$

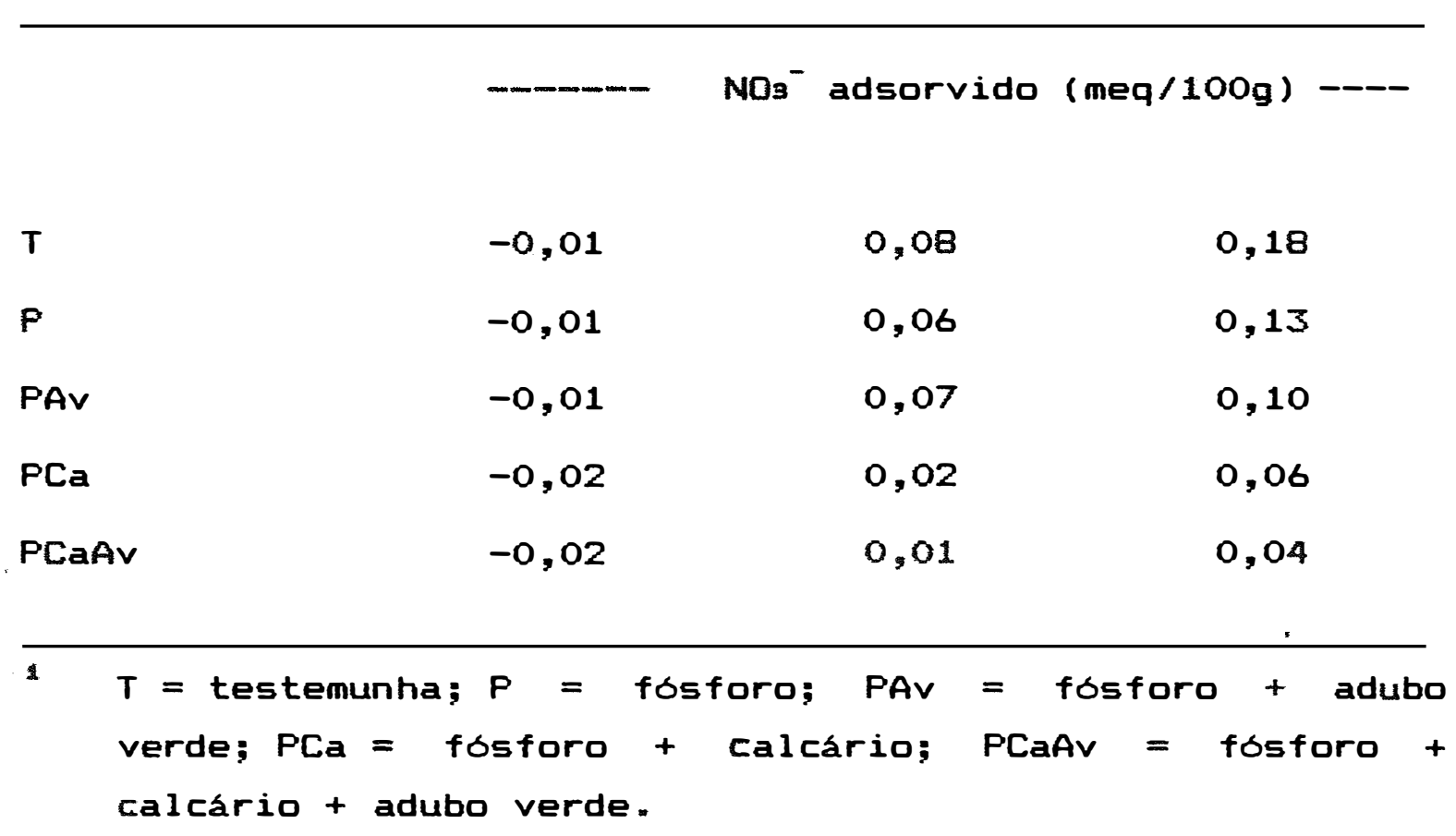


Os dados da tabela 11 mostram que a adsorçăo de nitrato na camada de 0 - $20 \mathrm{~cm}$ foi negativa em todos os tratamentos, ficando entre $-0,01$ e $-0,02$ meq/100g de solo. Nessa camada,à semelhança das demais, detectou-se a existencia de cargas eletricas positivas lavaliadas pela CTA - tabela 7) que permitiriam a adsorção do nitrato. No entanto, essas cargas poderiam já estar ocupadas com fosfato, sulfato, cloreto, e mesmo, nitrato. BLACK \& WARING (1976) tambem constataram a ocorrência de adsorçăo negativa aproximadamente da mesma magnitude $(-0,05$ e $-0,03$ meq/100g de solo) nas camadas de $0-10$ e 10 - $20 \mathrm{~cm}$ de um solo (krasnozem) de caracteristicas semelhantes ao usado neste trabalio. Os autores atribulram o fato à alta carga liquida negativa do solo nessas camadas, refletida pelo alto valor de $\Delta \mathrm{pH}$ negativo das mesmas $(-1,2)$.

No presente trabaliho, a carga liquida negativa, $\triangle \Delta \mathrm{pH}$ e $\mathrm{p}$ ptencial eletrico negativos foram mais elevados nas amostras da camada de $0-20 \mathrm{~cm}$, em relaçăo às demais (tabelas 5, 6 e 9, respectivamente). Isso pode explicar, em parte, a ocorréncia de exclusăo do nitrato naquela camada e adsorção nas camadas de 20 - 40 e 40 - 60 cm.

Abaixo da camada de $0-20 \mathrm{~cm}$, a adsorçăo foi positiva e crescente com a profundidade, registrando-se valores entre 0,01 e 0,08 meq/100g na camada de $20-40 \mathrm{~cm}$, e entre 0,04 e 0,18 meq/1009, na camada de $40-60 \mathrm{~cm}$. Estes 
resultados corroboram os obtidos por outros pesquisadores (SCHALSCHA et al., 1974a; BLACK \& WARING, 1976; CAHN et al., 1992), que relataram aumento da capacidade de adsorçăo de nitrato com o aumento da profundidade, no perfil de solos com carga variável.

Ds tratamentos com adubação fosfatada e com adubação fosfatada + calagem reduziram a capacidade de adsorção de nitrato do solo (tabela 11). Constituem exceçăo apenas os tratamentos P e PAv na camada de 0 - $20 \mathrm{~cm}$, que nå se diferenciaram da testemunha $(T)$. Os tratamentos que incluíram a calagem, além da adubaçăo fosfatada, foram mais eficientes em reduzir a capacidade de adsorção de nitrato. Isto pode ser constatado comparando-se os valores dos tratamentos P e PAv com os dos tratamentos PCa e PCaAv em todas as camadas. Na camada de $20-40 \mathrm{~cm}$, por exemplo, onde as diferenças foram maiores, a capacidade de adsorção de nitrato baixou de 0,06 e 0,07 meq/100g (nos tratamentos $P$ e PAv), para 0,02 e 0,01 meq/100g, nos tratamentos PCa e PCaAv, respectivamente. Os dados indicam pronunciado efeito da calagem sobre a adsorção, confirmando resultados de outros autores que registraram efeitos depressivos do aumento do $\mathrm{pH}$ sobre a adsorção do nitrato (KINJO \& PRATT, 1971a! BLACK \& WARING, 1976; TONER et al., 1989).

Em virtude do calcário e do fosfato apresentarem baixa mobilidade no solo, seus efeitos sobre a adsorção do nitrato nas camadas de 20 - $40 \mathrm{~cm}$ e 40 - $60 \mathrm{~cm}$ 
devem ter sido indiretos. Uma possivel causa para a redução da adsorção seria o bloqueio de sitios de carga positiva por ânions orgånicos lixiviados da camada arável. Outra hipótese seria a de que ânions inorgånicos como o cloreto laplicado em grandes quantidades nas adubaçöes, sob a forma de cloreto de potássiol e/ou sulfato, seriam lixiviados da camada arável, mais eletronegativa, indo competir com o nitrato pelos sitios de adsorção nas camadas de $20-40$ e 40 - $60 \mathrm{~cm}$. Estudos de equilibrio de troca aniónica em solos com cargas positivas realizadas por KINJO \& PRATT (1971b) e TONER et al. (1989) mostraram que o cloreto e o sulfato apresentam preferencia sobre o nitrato em termos de adsorçă, o que vem reforçar esta última hipótese.

De modo geral, os resultados aqui relatados deixam claro que a calagem e a adubação fosfatada reduzem a capacidade de adsorção de nitrato em solos de carga variável, inclusive nas camadas abaixo de $20 \mathrm{~cm}$. Os dados obtidos confirmam as indicaçơes da literatura, e demonstram o efeito residual dessas práticas de manejo sob condiçơes de campo, um aspecto ainda pouco investigado nos estudos de adsorção de nitrato nos solos tropicais. 


\section{CONCLUSÖES}

Os resultados obtidos no presente trabalio permitem as seguintes conclusores:

- Tratamentos com fósforo (334 ppm) e fósforo (334 ppm) + calcário (5,5 t/ha), aplicados parceladamente ao longo de seis anos, num latossolo vermelho-escuro submetido a dezessete cultivos com arroz, feijão, trigo ou milho, aumentaram a carga liquida negativa e a CTC ao pH natural do solo, e reduziram sua capacidade de adsorção de fosfato, sulfato e nitrato. Os efeitos do tratamento com fósoro $(334 \mathrm{ppm})+$ calcário $(5,5 \mathrm{t} / \mathrm{ha})$ sobre estas caracteristicas foram mais acentuados do que as do tratamento com fósforo $(334 \mathrm{ppm})$.

- Ds tratamentos não influenciaram o ponto de carga zero (PCZ), a capacidade de troca de ånions (CTA) ao pH natural do solo, e a CTC ao pH 7,0.

- A adubação verde ( 16 t/ha, matéria seca), associada incorporação dos residuos das culturas e na presença de fósforo (334 ppm) ou fósforo (334 ppm) + calcário (5,5 t/ha), não afetou as propriedades eletroquímicas ou a capacidade de retenção aniónica do solo. 


\title{
REFERENCIAS BIBLIQGRAF ICAS
}

\author{
AMARASIRI, S.L. \& OLSEN, S.R. Liming as related to \\ solubility of $P$ and plant growth in an acid tropical soil. \\ Soil Science Society of America Proceedings, \\ Madison, $37(5)=716-21,1973$.
}

APPELT, H.; COLEMAN, N.T.; PRATT, P.F. Interactions between organic compounds, minerals, and ions in volcanic - ash derived soils. II. Effects of organic compounds on the adsorption of phosphate. Soil Science Society of America Proceedings, Madison, $39(4)=628-30,1975$.

BAKER, A.S. Colorimetric determination of nitrate in soil and plant extracts with brucine. Journal of Agricultural and Food Chemistry, Easton, 17(4):802, 1969.

BARDSLEY, C.E. \& LANCASTER, J.D. Sulfur. In: BLACK, C.A., ed. Methods of soil analysis. Madison, American Society of Agronomy, 1965. pt 2; Chemical and Microbiological Properties, p. 1112 - 6. (Agronomy, 9). 
BARROW, N.J. Comparison of the adsorption of molybdate, sulfate and phosphate by soils. Soil Science, Baltimore, $109(5): 282-8, \quad 1970$.

BARROW, N.J. Effect of previous additions of phosphate on phosphate sorption by soils. Soil Science, Baltimore, $118(2): 82-9, \quad 1974$.

BARROW, N.J. Reactions of anions and cations with variable charge soils. Advances in Agronomy, New York, 38:183-230, 1985.

BLACK, A.S. \& WARING, S.A. Nitrate leaching and adsorption in a krasnozen from Redland Bay, Qld. II. Soil factors influencing adsorption. Australian Journal of Soil Research, Melbourne, 14(2): 181-8, 1976.

BLACK, A.S. \& WARING, S.A. Adsorption of nitrate, chloride and sulfate by some highly weathered soils from south-east Queensland. Australian Journal of Soil Research, Melbourne, 17(2):271-82, 1979.

BOLAN, N.S. \& BARROW, N.J. Modelling the effect of adsorption of phosphate and other anions on the surface charge of variable charge oxides. Journal of Soil Science, $0 \times$ ford, $35(2): 273-81,1984$. 
BOLAN, N.S.; SYERS, J.K.; TILLMAN, R.W. IOnic strength effects on surface charge and adsorption of phosphate and sulfate by soils. Journal of Soil Science, Oxford, $37(3): 379-88, \quad 1986$.

BOLAN, N.S.; SYERS, J.K.; TILLMAN, R.W.; SCOTTER, D.R. Effect of liming and phosphate additions on sulfate leaching in soils. Journal of Soil Science, Oxford, $39(4): 493-504,1988$.

BORNEMISZA, E. \& LLANOS, R. Sulfate movement, adsorption and desorption in three Costa Rican soils. Soil Science Society of America Proceedings, Madison, 31(3):356-60, 1967.

BDWDEN, J.W.; NAGARAJAH, 5.; BARROW, N.J.; QUIRK, J.P. Describing the adsorption of phosphate, citrate and selenite on a variable - charge mineral surface. Australian Journal of Soil Research, Melbourne, $18(1): 49-60,1980$.

CAHN, M.D.; BOULDIN, D.R.; CRAVO, M.S. Nitrate sorption in the profile of an acid soil. Plant and Soil, Dordrecht, $143(2): 179-83,1992$. 
CAMARGO, O.A.; MONIZ, A.C.; JORGE, J.A.; VALADARES, J.M.A.S. Metodos de anâlise quimica, mineralógica e fisica de solos do Instituto Agronomico de Campinas. Campinas, Instituto Agronómico, 1986. (IAC. Boletim Técnico, 106).

CAMARGO, O.A. \& RAIJ, B. van Movimento de gesso em amostras de latossolos com diferentes propriedades eletroquimicas. Revista brasileira de Ciencia do Solo, Campinas, $13(3): 275-80, \quad 1989$.

CHAO, T.T. Anionic effects on sulfate adsorption by soils. Soil Science Society of America Proceedings, Madison, $28(4): 581-3, \quad 1964$

CHAO, T.T.; HARWARD, M.E.; FANG, S.C. Movement of $S^{95}$ tagged sulfate through soil columns. Soil Science Society of America Proceedings, Madison, 26(1):27-32, 1962.

COUTO, W.; LATHWELL, D.J.; BOULDIN, D.R. Sulfate sorption by two Dxisols and one Alfisol of the tropics. Soil Science, Baltimore, $127(2): 108-16,1979$.

CURTIN, D. \& SYERS, J.K. Mechanism of sulphate adsorption by two tropical soils. Journal of Soil Science, Oxford, $41(2): 295-304,1990$ 
DALTON, J.D.; RUSSEL, G.C.; SIELING, D.H. Effect of organic matter on phosphate availability. Soil science, Baltimore, $73(3): 173-8,1952$.

DEB, D.L. \& DATTA, N.P. Effect of associating anions on phosphorus retention in soil: II. Under variable anion concentration. Plant and Soil, Dordrecht, $25(3): 432-44, \quad 1967$.

EASTERWOOD, G.W. \& SARTAIN, J.B. Clover residue effectiveness in reducing ortophosphate sorption on ferric hydroxide coated soil. Soil Science Society of America Proceedings, Madison, 54(5):1345-50, 1990.

FASSBENDER, H.W. Estudio de fosforo en suelos de America Central. IV. Capacidad de fijación de fosforo y su relación con las caracteristicas edaficas. Turrialba, San Jose, $19(4)$ : 497-505, 1969 .

FOX, R.L. \& KAMPRATH, E.J. Phosphate sorption isotherms for evaluating the phosphate requirement of soils. Soil Science Society of America Journal, Madison, 34(6):902-7, 1970 .

FOX, R.L.; OLSON, R.A. \& RHOADES, H.F. Evaluating the 5 status of soils by plant and soil tests. Soil Science Society of America Proceedings, Madison, 28(2):243-6, 
1964.

GEBHARDT, H. \& COLEMAN, N.T. Anion adsorption by allophanic tropical soils: II. Sulfate adsorption. Soil Science Society of America Proceedings, Madison, $38(2): 259-62$, 1974.

GILLMAN, G.P. A proposed method for the measurement of exchange properties of high - weathered soils. Australian Journal of Soil Research, Melbourne, 17(1):129-41, 1979.

GILLMAN, G.P. \& BELL, L.C. Surface charge characteristics of six weathered soils from tropical North Queensland. Australian Journal of Soil Research, Melbourne, $14(3): 351-60,1976$.

GILLMAN, G.P. \& BELL, L.C. Soil solution studies on weathered soil from tropical North Queensland. Australian Journal of Soil Research, Melbourne, 16(1):67-77, 1978.

GILLMAN, G.P. \& FOX, R.L. Increases in cation exchange capacity of variable charge soils following superphosphate applications. Soil Science Society of America Journal, Madison, $44(5)=934-8,1980$. 
GOLDBERG, 5. \& SPOSITO, G. On the mechanism of specific phosphate adsorption by hydroxylated mineral surfaces: a review. Communications in Soil Science and Plant Analysis, New York, 16(8):801-21, 1985.
GUADALIX, M.E. \& PARDO, M.T. Sulphate sorption by variable charge soils. Journal of Soil Science, Oxford, $42(4): 607-14,1990$.

HARTER, R.D. Phosphorus adsorption sites in soils. Soil Science Society of America Proceedings, Madison, $33(4): 630-2,1969$.

HARWARD, M.E. \& REISENAUER, H.M. Reactions and movement of inorganic soil sulfur. Soil Science, Baltimore, $101(4): 326-35, \quad 1966$.

HAYNES, R.J. Effects of liming on phosphate availability in acid soils: a critical review. Plant and Soil, Dordrecht, $68(3): 289-308, \quad 1982$.

HAYNES, R.J. Effect of lime and phosphate applications on the adsorption of phosphate, sulfate and molybdate by a spodosol. Soil Science, Baltimore, 135(4):221-7, 1983. 
HESSE, P.R. Sulfur and nitrogen changes in forest soils of East Africa. Plant and Soil, Dordrecht, 19(1):86-96, 1957.

HINGSTON, F.J.; POSNER, A.M.; QUIRK, J.P. Anion adsorption by goethite and gibbsite. I. The role of the proton in determining adsorption envelopes. Journal of Soil Science, Oxford, $23(2): 177-92,1972$.

HINGSTON, F.J.; ATKINSON, R.J.; FOSNER, A.M.; QUIRK, J.P. Specific adsorption of anions. Nature, London, 215: 1459-61, sept. 1967.

HUE, N.V.; ADAMS, F.; EVANS, C.E. Sulfate retention by an acid Be horizon of an ultisol. Soil Science Society of America Journal, Madison, 49(5):1196-200, 1985.

JACKSON, M.L. Soil chemical analysis. Advanced course. Madison, University of Wisconsin, 1969. 895p.

JOHNSON, D.W. \& HENDERSON, G.S. Sulfate adsorption and sulfur fractions in a highly weathered soil under a mixed deciduous forest, Soil Science, Baltimore, 128(1):34-40, 1979. 
JOHNSON, D.W. \& TODD, D.E. Relationships among iron, aluminum, carbon and sulfate in a variety of forest soils. Soil Science Society of America Journal, Madison, $47(4): 792-800, \quad 1983$.

JOHNSON, D.W.; COLE, D.W.; GESSEL, S.P. Acid precipitation and soil sulfate adsorption properties in a tropical and in a temperate soil. Biotropica, Washington, 11(1):38-42, 1979.

KAFKAFI, U.; BAR-YOSEF, B.; ROSENBERG, R.; SPOSITO, G. Phosphorus adsorption by kaolinite and montmorilonite: II. Organic anion competition. Soil Science Society of

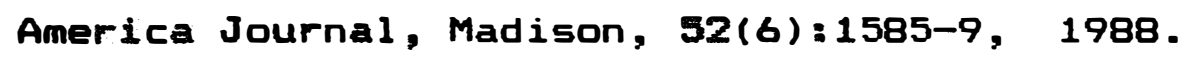

KILMER, V.J. \& ALEXANDER, L.T. Methods of making mechanical analysis of soils. Soil Science, Baltimore, 68(1):15-24, 1949.

KINJO, T. \& PRATT, P.F. Nitrate adsorption: I. In some acid soils of Mexico and South America. Soil Science Society of America Proceedings, Madison, 35(5):722-5, 1971 .

KINJO, T. \& PRATT, P.F. Nitrate adsorption: II. In competition with chloride, sulfate and phosphate. Soil Science Society of America Proceedings, Madison, $35(5)$ : 725-8, $1971 b$. 
KINJO, T. \& PRATT, P.F. Nitrate adsorption: III. Desorption, movement and distribution in Andepts. Soil Science Society of America Proceedings, Madison, $35(5): 728-32, \quad 1971 c$.

KWONG, K.F. Ng KEE, \& HUANG, P.M. Sorption of phosphate by hydrolitic reaction products of aluminium. Nature, London, $271(5643)$ : 336-8, 1978.

LAVERDIERE, M.R. Effects of phosphate additions on the charge properties of a podzolic $B$ horizon.

Canadian Journal of Soil Science, Ottawa, 62(3):519-25, 1982.

LEAL, J.R. \& VElloso, A.C.X. Adsorção de fosfato em latossolos sob vegetação de Cerrado. Pesquisa Agropecuária Brasileira, Brasilia, 8(7):81-8, 1973.

LE MARE, P.H.; PEREIRA, J.; GOEDERT, W. Effects of green manure on isotopically exchangeable phosphate in a dark-red latosol in Brazil. Journal of Soil Science, Oxford, $38(2): 199-209,1987$.

LOPEZ-HERNANDEZ, D.; FLORES; D =; SIEGERT, G.; RODRIGUEZ, J.V. The effect of some organic anions on phosphate removal from acid and calcareous soils. Soil Science, Baltimore, $128(6): 321-6, \quad 1979$. 
MARCANO-MARTINEZ, E. \& MCBRIDE, M.B. Calcium and sulfate retention by two Oxisols of the brazilian Cerrado. Soil Science Society of America Journal, Madison, 53(1):63-9, 1989.

MARSH, K.B.; TILLMAN, R.W.; SYERS, J.K. Charge relationships of sulfate sorption by soils. Soil Science Society of America Journal, Madison, $51(2): 318-23,1987$.

MCKEAGUE, J.A. \& DAY, J.H. Dithionite and oxalate extractable $F e$ and $A l$ as aids in differentiating various classes of soils. Canadian Journal of Soil Science, Ottawa, $46(1): 13-22,1966$.

MEAD, J.A. A comparison of the Langmuir, Freundlich and Temkin equations to describe phosphate adsorption properties of soils. Australian Journal of Soil Research, Melbourne, $19(4): 333-42,1981$.

MEKARU, T. \& UEHARA, G. Anion adsorption in ferruginous tropical soils. Soil Science Society of America Proceedings, Madison, 36(2):296-300, 1972.

MORAES, J.F.V. Movimento de nutrientes em Latossolo Vermelho-escuro. Pesquisa Agropecuária Brasileira, Brasilia, 26(1):85-97, 1991 . 
MORAIS, F.I.; PAGE, A.L.; LUND, L.J. The effect of pH, salt concentration and nature of eletrolytes on the charge characteristics of Brazilian tropical soils. Soil Science Society of America Journal, Madison, 40(4):521-7, 1976.

MOSHI, A.O.; WILD, A.; GREENLAND, D.J. Effect of organic matter on the charge and phosphate adsorption characteristics of Kikuyu Red Clay Loam from Kenya. Geoderma, Amsterdam, 11(2):275-85, 1974.

MOTT, C.J.B. Anion and ligand exchange. In: GREENLAND, D.J. \& HAYES, M.B.H., ed. Chemistry of soil processes. New York, John Wiley, 1981. p.171-219.

MULJADI, D.; POSNER, A.M.; QUIRK, J.P. The mechanism of phosphate adsorption by kaolinite, gibbsite and pseudobohemite. I. The isotherms and the effect of $\mathrm{pH}$ on adsorption. Journal of Soil Science, Oxford, $17(2): 212-29, \quad 1966$.

MUNNS, D.N. \& FOX, R.L. The slow reaction which continues after phosphate sorption: kinetics and equilibrium in some tropical soils = Soil Science Society of America Journal, Madison, $40(1): 46-51,1976$. 
MURPHY, J. \& RILEY, J.P. A modified single solution method for determination of phosphate in natural waters. Analytica Chimica Acta, Amsterdam, 27(1):31-6, 1962.

NAGARAJAH, S.; FOSNER, A.M.; QUIRK, J.P. Competitive adsorption of phosphate with polygalacturonate and other organic anions on kaolinite and oxide surfaces. Nature, London, $228(5266): 83-5,1970$.

NAIDU, R.; SYERS, J.K.; TILLMAN, R.W.; KIRKMAN, J.H. EffEct of liming and added phosphate on charge characteristics of acid soils. Journal of Soil Science, Oxford, $41(1): 157-64, \quad 1990 \mathrm{a}$.

NAIDU, R.; SYERS, J.K.; TILLMAN, R.W.; KIRKMAN, J.H. Effect of liming on phosphate sorption by acid. soils. Journal of Soil Science, Oxford, $41(1)=165-75,19906$.

NODUIN, S.C.; DRISCOLL, C.T.; LIKENS, G.E. The effect of pH on sulfate adsorption by a forest soil. Soil Science, Baltimore, $142(2): 69-75,1986$.

ONKEN, A.B. \& SUNDERMAN, H.D. Colorimetric determination of exchangeable ammonium, urea, nitrate and nitrite in a single soil extract. Agronomy Journal, Madison, $69(1): 45-53, \quad 1977$. 
OWUSU-BENNOAH, E. \& ACQUAYE, D.K. Phosphate sorption characteristics of selected major Ghanaian soils. Soil Science, Baltimore, $148(2)=114-23,1989$.

OZANNE, P.G. \& SHAW, T.C. Advantages of the recently developed phosphate adsorption test over the older extractant methods for soil phosphate. INTERNATIONAL CONGRESS OF SOIL SCIENCE, 9th, Adelaide, 1968. Transactions, 1968. part 2. p.273-80.

PARDO, M.T. \& GUADALIX, M.E. Phosphate sorption in allophanic soils and release of sulphate, silicate and hydroxyl. Journal of Soil Science, Oxford, 41(4):607-12, 1990.

PARFITT, R.L. Phosphate adsorption on an oxisol. Soil Science Society of America Journal, Madison, 41(6): 1064-7, 1977.

PARFITT, R.L. Anion adsorption by soils and soil materials. Advances in Agronomy, New York, 30:1-50, 1978.

PARFITT, R.L. \& RUSSEL, J.D. Adsorption on hydrous oxides: IV. Mechanism of adsorption of various ions on goethite. Journal of Soil Science, Oxford, 28(2):297-305, 1977. 
PARFITT, R.L. \& SMART, R. St. C. The mechanism of sulfate adsorption on iron oxides. Soil Science Society of America Journal, Madison, 42(1):48-50, 1978.

PARFITT, R.L.; ATKINSON, R.J.; SMART, R. St. C. The mechanism of phosphate fixation on iron oxides. Soil Science Society of America Proceedings, Madison, $39(5): 837-41, \quad 1975$.

PARFITT, R.L.; FRASER, A.R.; RUSSEL, J.D.; FARMER, V.C. Adsorption on hydrous oxides: I I. Qxalate, benzoate and phosphate on gibbsite. Journal of Soil Science, Madison, $28(1): 40-7, \quad 1977$.

PEECH, M. Hydrogen-ion activity. In: BLACK, C.A., ed. Methods of soil analysis. Madison, American Society of Agronomy, 1965. pt.2: Chemical and Microbiological Properties, p.914-26. (Agronomy, 9).

RAIJ, B. van. Determinação do ponto de carga zero em solos. Bragantia, Campinas, $32(18): 337-47,1973$.

RAIJ, B. van \& CAMARGO, O.A. Nitrate elution from soil columns of three $0 \times i s o l s$ and one Alfisol. In: INTERNATIONAL CONGRESS OF SOIL SCIENCE, 10., MOSCOW, 1974. Transactions. Moscow, Nauka Publishing House, 1974. vol. I I, P. 385-91. 
RAIJ, B. van \& QUAGgIO, J.A. Metodos de análise de solo para fins de fertilidade. Campinas, Instituto Agronómico, 1983. 31p. (IAC. Boletim Técnico, 81).

RAIJ, B. van \& PEECH, M. Eletrochemical properties of some Oxisols and Alfisols of the tropics. Soil Science Society of America Proceedings, Madison, 36(4):587-93, 1972.

RAJAN, 5.5.5. Sulfate adsorbed on hydrous alumina, ligands displaced, and changes in surface charge. Soil Science Society of America Journal, Madison, 42(1):39-44, 1978.

RAJAN, 5.5.5. Adsorption and desorption of sulfate and charge relationships in allophanic clays. Soil Science Society of America Journal, Madison, 43(1):65-9, 1979.

REEVE, N.G. \& SUMNER, M.E. Effects of aluminium toxicity and phosphorus fixation on crop growth on Oxisols in Natal. Soil Science Society of America Proceedings, Madison, $34(2): 263-7, \quad 1970$.

RENNIE, D.A. \& MCKERCHER, R.B. Adsorption of phosphorus by four Saskatchewan soils. Canadian Journal of Soil Science, Ottawa, 39(1):64-75, 1958. 
RYDEN, J.C.; SYERS, J.K.; TILLMAN, R.W. Inorganic anion sorption and interactions with phosphate sorption by hydrous ferric oxide gel. Journal of Soil Science, Oxford, $38(2): 211-17,1987$.

SANCHEZ, P.A. Properties and management of soils in the tropics. New York, John Wiley, 1976. 618p.

SANCHEZ, P.A. \& UEHARA, G. Management considerations for acid soils with high phosphorus fixing capacity. In: KHASAWNEH, F.E.; SAMPLE, E.C.; KAMPRATH, E.J., ed. The role of phosphorus in agriculture. Madison, SSSA/ASA/CSSA. 1980. P.471-514.

SAWHNEY, B.L. Charge characteristics of soils as affected by phosphate sorption. Soil Science Society of America Proceedings, Madison, $38(1)=159-60,1974$

SCHALSCHA, E.B.; PRATT, P.F.; DOMECQ, T.C. Nitrate adsorption by some volcanic-ash soils of southern Chile. Soil Science Society of America Proceedings, Madison, $38(1)=44-5, \quad 1974 a$.

SCHALSCHA, E.B.; PRATT, P.F.; SOTO, D. Effect of phosphate adsorption on the cation-exchange capacity of volcanic ash soils. Soil Science Society of America Proceedings, Madison, $38(3)$ :539-40, $1974 \mathrm{~b}$. 
SHARPLEY, A.N. \& SMITH, S.J. Mineralization and leaching of phosphorus from soil incubated with surface - applied and incorporated crop residue. Journal of Environmental Quality, Madison, 18(1): 101-5, 1989 .

SINGH, B.R. Sulfate sorption by acid forest soils: 1. Sulfate adsorption isotherms and comparison of different equations in describing sulfate adsorption. Soil Science, Baltimore, $138(3): 189-97,1984$.

SINGH, B.R. \& KANEHIRO, Y. Adsorption of nitrate in amorphous and kaolinitic Hawailan soils. Soil Science Society of America Proceedings, Madison, 33(5):681-3, 1969.

SIQUEIRA, C.; LEAL, J.R.; VELLOSO, A.C.X.; SANTOS, G.A. Eletroquímica de solos tropicais de carga variável: II. Quantificação do efeito da materia orgânica sobre o ponto de carga zero. Revista Brasileira de Ciencia do Solo, Campinas, $14(1): 13-7,1990$.

SMYTH, T.J. \& SANCHEZ, P.A. Effects of lime, silicate and phosphorus application to an Oxisol on phosphorus sorption and ion retention. Soil Science Society of America Journal, Madison, 44(3):500-5, 1980. 
STRUTHERS, P.H. \& SIELING, D.H. Effect of organic anions on phosphate precipitation by iron and aluminum as influenced by pH. Soil Science, Baltimore, 69:205-13, Jan./June, 1950 .

SWENSON, R.M.; COLE, C.V.; SIELING, D.H. Fixation of phosphate by iron and aluminum and replacement by organic and inorganic ions. Soil Science, Baltimore, $67(1): 3-22$, 1949.

TATE, K.R. \& THENG, B.K.G. Organic matter and its interactions with inorganic soil constituents. In: THENG, B.K.G., ed. Soils with variable charge. Palmerston North, New Zealand Society of Soil Science, 1980 . p. $225-49$

TONER IV, C.V.; SPARKS, D.L.; CARSKI, T.H. Anion exchange chemistry of Middle Atlantic soils: charge properties and nitrate retention kinetics. Soil Science Society of America Journal, Madison, 53(4):1061-7, 1989.

TURNER, L.J. \& KRAMER, J.R. Sulfate ion binding on goethite and hemathite. Soil Science, Baltimore, 152(3):226-30, 1991. 
UEHARA, G. \& KENG, J. Management implications of soil mineralogy in Latin America. In: BORNEMIZA, E. \& ALVARADO, A., ed. Soil management in tropical America. Raleigh, North Carolina State University, 1975. P.351-63.

UEHARA, G. \& GILLMAN, G.P. Charge characteristics of soils with variable and permanent charge minerals: I. Theory. Soil Science Society of America Journal, Madison, $44(2): 250-5, \quad 1980$.

UEHARA, G. \& GILLMAN, G.P. The mineralogy, chemistry and physics of tropical soils with variable charge clays. Boulder, Westview Press, 1981. 170p.

VOLKWEISS, S.J. Factors affecting phosphate sorption by soils and minerals. Madison, University of Wisconsin, 1973. PhD. Thesis. 138p.

WALKLEY, A. \& BLACK, I.A. An examination of the Degtajereff method for determination of soil organic matter and a proposed modification of the cromic acid titration. Soil Science, Baltimore, 37(1):29-38, 1934 .

WANN, S.5. \& UEHARA, G. Surface charge manipulation in constant surface potential colloids. I. Relation to 
sorbed phosphorus. Soil Science Society of America Journal, Madison, 42(4):565-70, 1978 .

WILLIAMS, C.H. \& STEINBERGS, A. The evaluation of plant-available sulfur in soils. 2. The availability of adsorbed and insoluble sulfates. Plant and Soil, Dordrecht, 21(1):50-62, 1964.

WONG, M.T.F.; HUGHES, R.; ROWELL, D.L. Retarded leaching of nitrate in acid soils from the tropics: measurement of the effective anion exchange capacity. Journal of Soil Science, Oxford, 41(4):655-63, 1990.

WONG, M.T.F.; WILD, A.; JUO, A.S.R. Retarded leaching of nitrate measured in monolith lysimeters in south east Nigeria. Journal of Soil Science, Oxford, 38(3):511-8, 1987.

YOUNGE, O.R. \& PLUCKNETT, D.L. Quenching the high phosphorus fixation of Hawailan latosols. Soil Science Society of America Proceedings, Madison, 30(5):653-5, 1966.

ZHANG, G.Y.; ZHANG, X.N.; YU, T.R. Adsorption of sulphate and fluoride by variable charge soils. Journal of Soil Science, Oxford, $39(1): 29-38,1987$. 
$A P \hat{E} N D I C E$ 
Apéndice 1 - Dados experimentais das curvas de titulação potenciometrica das amostras do latossolo vermelho-escuro en trés concentraçơses de $\mathrm{KCl}$ $\left(C_{1}=0,1 M ; C_{2}=0,01 M ; C_{9}=0,001 M\right)-$ média de duas repetiçశes.

pH de equilitorio

\section{$\mathrm{C}_{1}$}

$\mathrm{C}_{2}$

C9

Ci

T $0-20 \mathrm{~cm}$

2,84

3,07

3,35

3,72

4,23

4,98

5,85

6,51

2,79

2,96

3,24

3,58

4,12

4,81

5,62

6,30
2,69

2,90

3,26

3,72

4,68

5,78

6,60

7,21

2,67

2,68

2,86

3,14

3,90

2,85

3,18

3,66

4,58

5,66

6,44

7,01
$\mathrm{H}^{+} / \mathrm{OH}^{-}$adsorvidos (meq/100g)

Cэ

$\begin{array}{lll} & H^{+} & \\ 2,15 & 1,86 & 1,83 \\ 1,52 & 1,32 & 1,21 \\ 0,75 & 0,70 & 0,63 \\ 0,09 & 0,09 & 0,06\end{array}$

$\mathrm{OH}^{-}$

$0,74 \quad 0,50$

$1,51 \quad 1,20$

2,50

2,23

3,46

3,08

5,68

6,44

7,10

7,86

P o $-20 \mathrm{~cm}$

2,67

0,69

1,62

2,50

3,46

$\mathrm{H}^{+}$

2,07

1,40

0,69

0,13

3,86

5,52

6,29

0,69

1,62

6,92

2,50

3,46

$\mathrm{DH}^{-}$

7,65

1,81

1,81

1,24

1,16

0,64

0,62

0,11

0,06

0,74

. 0,50

1,51

1,20

2,50

2,23

3,46

3,08 
Apêndice 1 - Dados experimentais das curvas de titulaçăo potenciometrica das amostras do latossolo vermelho-escuro em três concentraçớs de $\mathrm{KCl}$ $\left(C_{1}=0,1 M ; C_{2}=0,01 M ; C_{3}=0,001 M\right)-$ média de duas repetiçỡes.

$\mathrm{pH}$ de equilibrio

$\mathrm{H}^{+} / \mathrm{OH}^{-}$adsorvidos (meq/100g)

$\mathrm{C}_{2}$

Cэ

$\mathrm{C}_{1}$

$\mathrm{C2}$

C3

$$
\text { PAV } 0-20 \mathrm{~cm}
$$

2,77

3,00

3,24

3,60

4,10

4,76

5,60

6.25

2,66

2,93

3,22

3,67

2,67

2,84

2,03

1,44

3,14

0,69

3,86

0,12

4,58

5,66

5,55

0,69

6,30

1,62

6,90

2,50

7,59

3,46

7,06

PCa $0-20 \mathrm{~cm}$

2.78

3,00

3,28

3,62

2,67

2,94

3,22

3,70

2,69

2,86

3,14

3,89

2,05

1,44

0,71

0,12

5,60

0,69

6,45

1,62

6,98

2,50

7,70

3,46
4,16

5,72

6,50
6,53

7,26
$\mathrm{H}^{+}$

1,78

1,81

1,36

1,18

0,67

0,64

0,10

0,06

$\mathrm{OH}^{-}$

0,74

0,50

1,51

1,20

2,50

2,23

3,46

3,08

$\mathrm{H}^{+}$

$1,78 \quad 1,86$

1,37

1,21

0,67

0,64

0,10

0,06

$\mathrm{OH}^{-}$

$0,74 \quad 0,50$

1,51

1,20

2,50

2,23

3,46

3,08 
Apêndice 1 - Dados experimentais das curvas de titulação potenciometrica das amostras do latossolo vermelho-escuro en tress concentraçбes de KCl $\left(C_{1}=0,1 M ; C_{2}=0,01 M ; C_{9}=0,001 M\right)-$ media de duas repetiçశes.

pH de equilibrio

\section{$C_{1}$}

$\mathrm{C}_{2}$

Cэ

$C_{1}$

$\mathrm{C}_{2}$

Cэ

PCaAv $0-20 \mathrm{~cm}$

$\begin{array}{llllll}2,85 & 2,70 & 2,74 & 2,17 & 1,88 & 1,97 \\ 3,04 & 3,01 & 2,92 & 1,49 & 1,46 & 1,30 \\ 3,33 & 3,30 & 3,22 & 0,74 & 0,72 & 0,70 \\ 3,66 & 3,76 & 3,98 & 0,11 & 0,08 & 0,05 \\ 4,16 & 4,69 & 5,71 & 0,69 & 0,74 & 0,50 \\ 4,94 & 5,79 & 6,47 & 1,62 & 1,51 & 1,20 \\ 5,74 & 6,60 & 7,02 & 2,50 & 2,50 & 2,23 \\ 6,41 & 7,33 & 7,83 & 3,46 & 3,46 & 3,08\end{array}$

$\mathrm{T} 20-40 \mathrm{~cm}$

$\begin{array}{llllll}2,96 & 2,82 & 2,79 & 2,33 & 2,12 & 2,07 \\ 3,22 & 3,08 & 3,00 & 1,64 & 1,53 & 1,40 \\ 3,56 & 3,48 & 3,34 & 0,84 & 0,81 & 0,77 \\ 3,94 & 4,03 & 4,14 & 0,06 & 0,04 & 0,03\end{array}$

4,67

5,16

6,10

0,69

$\mathrm{OH}^{-}$

5,66

6,44

7,00

1,62

0,74

0,50

6,46

7,70

2,50

1,51

1,20

7,13

7,28

8,46

3,46

2,50

2,23

8,16

3,46

3,08 
Apêndice 1 - Dados experimentais das curvas de titulaçăo potenciometrica das amostras do latossolo vermelho-escuro em três concentraçơes de $\mathrm{KCl}$ $\left(C_{1}=0,1 M ; C_{2}=0,01 M ; C_{3}=0,001 M\right)-\operatorname{média~de~}$ duas repetiçỡes.

$\mathrm{pH}$ de equilibrio

\section{Cis}

C2

C9

$C_{1}$

$\mathrm{C2}$

C9
$\mathrm{H}^{+} / \mathrm{OH}^{-}$adsorvidos (meq/100g)

$P 20-40 \mathrm{~cm}$

2,92

2,78

2,74

2,28

1,59

2,94

0,79

3,37

3,24

0,07

3,86

3,92

4,06

5,02

6,34

7,15

7,98

5,92

0,69

6,88

1,62

7,44

2,50

8,28

3,46

PAV $20-40 \mathrm{~cm}$

$$
2,87
$$

3,14

3,44

3,86

4,48

5,40

6,24

6,94
2,77

3,01

3,36

3,92

5,00

6,32

7,12

7,95
2,76

2,96

3,26

4,05

5,96

6,75

7,60

8,24
2,20

1,58

0,79

0,07

0,69

1,62

2,50

3,46
$\mathrm{H}^{+}$

2,05

1,97

1,47

1,33

0,76

0,71

0,06

0,04

$\mathrm{DH}^{-}$

0,74

0,50

1,51

1,20

2,50

2,23

3,46

3,08 
Apendice 1 - Dados experimentais das curvas de titulaçăo potenciométrica das amostras do latossolo vermelho-escuro em três concentraçסes de $\mathrm{KCl}$ $\left(C_{1}=0,1 M ; C_{2}=0,01 M ; C_{9}=0,001 M\right)-$ média de duas repetiçỡes.

pH de equilibrio

$\mathrm{Cl}_{1}$

$C_{2}$

Cэ

$C_{1}$

C2

Cэ
PCa $20-40 \mathrm{~cm}$

$\begin{array}{llllll}2,95 & 2,79 & 2,75 & 2,32 & H^{+} & 2,07 \\ 3,24 & 3,03 & 2,96 & 1,66 & 1,48 & 1,99 \\ 3,54 & 3,43 & 3,28 & 0,83 & 0,79 & 0,74 \\ 3,96 & 3,97 & 4,08 & 0,05 & 0,05 & 0,04 \\ 4,64 & 5,08 & 6,10 & 0,69 & 0,74 & 0,50 \\ 5,54 & 6,48 & 6,93 & 1,62 & 1,51 & 1,20 \\ 6,41 & 7,32 & 7,82 & 2,50 & 2,50 & 2,23 \\ 7,14 & 8,14 & 8,46 & 3,46 & 3,46 & 3,08\end{array}$

PCaAv 20 - 40 cm

$\mathrm{H}^{+}$

2,96

2,78

2,76

2,33

2,05

2,01

3,22

3,04

2,97

1,64

1,49

1,36

3,54

3,41

3,28

0,83

0,78

0,74

3,97

3,98

4,10

0,05

0,05

0,04

4,62

5,08

6,09

0,69

$\mathrm{OH}^{-}$

5,48

6,44

7,01

1,62

0,74

0,50

6, 42

7,32

7,94

2,50

1,51

1,20

7,18

8,11

8,46

3,46

2,50

2,23

3,46

3,08 
Apéndice 1 - Dados experimentais das curvas de titulaçăo potenciométrica das amostras do latossolo vermelho-escuro em trés concentraçбes de KCl $\left(C_{1}=0,1 M ; C_{2}=0,01 M ; C_{3}=0,001 M\right)-$ média de duas repetiçชes.

pH de equilibrio

$\mathrm{H}^{+} / \mathrm{OH}^{-}$adsorvidos (meq/100g)

$C_{i}$

$\mathrm{Cr}$

Ca

$\mathrm{C}_{1}$

C2

Cэ

T $40-60 \mathrm{~cm}$

\begin{tabular}{|c|c|c|c|c|c|}
\hline & & & & $\mathbf{H}^{+}$ & \\
\hline 3,30 & 3,00 & 2,94 & 2,63 & 2,38 & 2,30 \\
\hline 3,58 & 3,35 & 3,19 & 1,81 & 1,72 & 1,58 \\
\hline 3,91 & 3,74 & 3,52 & 0,91 & 0,88 & 0,85 \\
\hline \multirow[t]{2}{*}{4,48} & 4,40 & 4,45 & 0,02 & 0,02 & 0,01 \\
\hline & & & & $\mathrm{OH}^{-}$ & \\
\hline 5,42 & 5,84 & 6,58 & 0,69 & 0,74 & 0,50 \\
\hline 6,40 & 7,03 & 7,68 & 1,62 & 1,51 & 1,20 \\
\hline 7,08 & 7,98 & 8,48 & 2,50 & 2,50 & 2,23 \\
\hline 7,90 & 8,72 & 9,04 & 3,46 & 3,46 & 3,08 \\
\hline
\end{tabular}

P $40-60 \mathrm{~cm}$

$\begin{array}{llllll}3,24 & 2,92 & 2,89 & 2,59 & 2,28 & 2,23 \\ 3,53 & 3,27 & 3,14 & 1,80 & 1,68 & 1,54 \\ 3,88 & 3,70 & 3,48 & 0,91 & 0,88 & 0,83 \\ 4,42 & 4,34 & 4,38 & 0,02 & 0,02 & 0,02 \\ 5,40 & 5,76 & 6,47 & 0,69 & 0 H^{-} & \\ 6,32 & 6,98 & 7,56 & 1,62 & 1,51 & 1,20 \\ 7,10 & 7,98 & 8,37 & 2,50 & 2,50 & 2,23 \\ 7,70 & 8,68 & 8,98 & 3,46 & 3,46 & 3,08\end{array}$


Apêndice 1 - Dados experimentais das curvas de titulação potenciometrica das amostras do latossolo vermeliho-escuro em três concentraçðes de $\mathrm{KCl}$ $\left(C_{1}=0,1 M ; C_{2}=0,01 M ; C_{9}=0,001 M\right)-\operatorname{media}$ de duas repetiçర̃es.

pH de equilibrio

C1

$\mathrm{C} 2$

Cs

C1

$\mathrm{C}_{2}$

Cэ
PAV $40-60 \mathrm{~cm}$

3,00

3,46

3,78

4,28

5,22

6,21

7,04

7,82

2,88

3,19

3,62

4,25

2,84

3,09

3,44

4,32

2,38

1,77

0,89

0,02

6,48

0,69

7,56

1,62

8,42

2,50

8,88

3,46

8,68

PCa $40-60 \mathrm{~cm}$

3,11

2,88

3,19

2,84

2,49

3,08

1,77

3,45

0,89

4,32

0,02

6,42

0,69

7,44

1,62

8,39

2,50

8,94

3,46

6,27

7,92

8,71

7,90
$\mathrm{H}^{+}$

2,22

2,15

1,62

1,49

0,85

0,82

0,03

0,02

व

0,74

0,50

1,51

1,20

2,50

2,23

3,46

3,08

$\mathrm{H}^{+}$

2,22

2,15

1,62

1,48

0,86

0,82

0,02

0,02

$\mathrm{OH}^{-}$

0,74

0,50

1,51

1,20

2,50

2,23

3,46

3,08 
Apêndice 1 - Dados experimentais das curvas de titulaçăo potenciometrica das amostras do latossolo vermelho-escuro em tress concentraçชes de $\mathrm{KCl}$ $\left(C_{1}=0,1 M ; C_{2}=0,01 M ; C_{9}=0,001 M\right)-$ média de duas repetiçỡes.

pH de equilibrio

$\mathrm{H}^{+} / \mathrm{OH}^{-}$adsorvidos (meq/100g)

$\begin{array}{lllllll} & \mathrm{C}_{2} & \mathrm{C}_{9} & & \mathrm{C}_{1} & \mathrm{C}_{2} & \mathrm{C}_{9}\end{array}$

\begin{tabular}{rrrrrr}
\multicolumn{5}{c}{ PCaAV $40-60 \mathrm{~cm}$} \\
3,19 & 2,94 & 2,89 & 2,55 & 2,30 & 2,23 \\
3,52 & 3,26 & 3,14 & 1,79 & 1,67 & 1,54 \\
3,86 & 3,71 & 3,50 & 0,90 & 0,88 & 0,84 \\
4,44 & 4,36 & 4,40 & 0,02 & 0,02 & 0,02 \\
5,48 & 5,78 & 6,48 & 0,69 & 0,74 & 0,50 \\
6,40 & 7,02 & 7,60 & 1,62 & 1,51 & 1,20 \\
7,16 & 8,04 & 8,48 & 2,50 & 2,50 & 2,23 \\
8,01 & 8,75 & 9,00 & 3,46 & 3,46 & 3,08
\end{tabular}


Apêndice 2 - Dados experimentais das isotermas de adsorção de fóforo das amostras do latossolo vermelho-escuro, nos diferentes tratamentos - medias de duas repetiçశes.

\section{Tratamentos}

\begin{tabular}{|c|c|c|c|c|c|c|c|c|c|}
\hline \multicolumn{2}{|c|}{$T$} & \multicolumn{2}{|c|}{$\mathbf{P}$} & \multicolumn{2}{|c|}{ PAV } & \multicolumn{2}{|c|}{ PCa } & \multicolumn{2}{|c|}{ PCaAv } \\
\hline $\mathrm{Psol}^{1}$ & Pads ${ }^{2}$ & Psol & Pads & Psol & Pads & Psol & Pads & Psol & Pads \\
\hline \multicolumn{10}{|c|}{ - ppm -- } \\
\hline \multicolumn{10}{|c|}{$0-20 \mathrm{~cm}$} \\
\hline 0,3 & 207 & 0,7 & 203 & 0,6 & 204 & 0,7 & 203 & 0,8 & 202 \\
\hline 0,6 & 254 & 1,0 & 250 & 1,0 & 250 & 1,4 & 246 & 1,5 & 245 \\
\hline 0,8 & 312 & 1,6 & 304 & 1,7 & 303 & 2,0 & 300 & 2,2 & 298 \\
\hline 2,1 & 359 & 3,5 & 345 & 3,3 & 347 & 4,1 & 339 & 4,4 & 336 \\
\hline 2,9 & 391 & 4,9 & 371 & 4,7 & 373 & 5,5 & 365 & 6,0 & 360 \\
\hline 3,3 & 437 & $(4,9)^{9}$ & $(421)$ & 5,4 & 416 & 0,1 & 409 & 6,2 & 408 \\
\hline 7,8 & 542 & 10,9 & 511 & 10,7 & 513 & 12,5 & 495 & 13,7 & 483 \\
\hline \multicolumn{10}{|c|}{$20-40 \mathrm{~cm}$} \\
\hline 0,1 & 209 & 0,3 & 207 & 0,2 & 208 & 0,1 & 209 & 0,1 & 209 \\
\hline 0,2 & 258 & 0,4 & 256 & 0,3 & 257 & 0,2 & 258 & 0,3 & 257 \\
\hline 0,4 & 316 & 0,6 & 314 & 0,6 & 314 & 0,5 & 315 & 0,8 & 312 \\
\hline 0,8 & 372 & 1,1 & 369 & 1,1 & 369 & 1,2 & 368 & 1,5 & 365 \\
\hline 1,2 & 408 & 1,8 & .402 & 1,8 & 402 & 1,7 & 403 & 1,9 & 401 \\
\hline 1,8 & 452 & 2,3 & 447 & 2,2 & 448 & 2,2 & 448 & 2,6 & 444 \\
\hline 5,1 & 569 & 6,7 & 553 & 5,9 & 561 & 7,2 & 548 & 7,5 & 545 \\
\hline
\end{tabular}

Psol. = concentraçăo de fóstoro na soluçăo de equilibrio.

2

Pads. = concentraçăo de fósforo adsorvido ao solo.

( ) = Dados não utilizados no cáculo da curva de regreśsão, por serem muito discrepantes dos demais. 
Apendice 3 - Dados experimentais das isotermas de adsorçăo de sulfato das amostras do latossolo vermelho-escuro, nos diferentes tratamentos - modias de duas repetiçชes.

\section{Tratamentos}

\begin{tabular}{|c|c|c|c|c|c|c|c|c|c|}
\hline \multicolumn{2}{|c|}{$T$} & \multicolumn{2}{|c|}{$\mathbf{P}$} & \multicolumn{2}{|c|}{ PAV } & \multicolumn{2}{|c|}{ PCa } & \multicolumn{2}{|c|}{ PCaAv } \\
\hline sol! & $a d s^{2}$ & sol. & ads. & sol. & ads. & 501. & ads. & 01 . & ads. \\
\hline & & & & 0 & $-20 \mathrm{~cm}$ & & & & \\
\hline 6 & 40 & 8 & 20 & 8 & 20 & 9 & 10 & 9 & 10 \\
\hline 10 & 50 & 12 & 30 & 12 & 30 & 12 & 30 & 12 & 30 \\
\hline 14 & 70 & 17 & 40 & 16 & 50 & $(16)^{\circ}$ & $(50)$ & $(16)$ & $(50)$ \\
\hline 21 & 90 & 25 & 50 & 25 & 50 & 26 & 40 & 25 & 50 \\
\hline 28 & 100 & 32 & 60 & 32 & 60 & 32 & 60 & 33 & 50 \\
\hline (36) & $(170)$ & 45 & 80 & 45 & 80 & 46 & 70 & 46 & 70 \\
\hline 63 & 130 & 66 & 100 & 66 & 100 & 68 & 80 & 67 & 90 \\
\hline 92 & 140 & 94 & 120 & 94 & 120 & 96 & 100 & 95 & 110 \\
\hline 118 & 140 & 119 & 130 & 122 & 100 & 122 & 100 & 121 & 120 \\
\hline & & & & 20 & $-40 \mathrm{~cm}$ & & & & \\
\hline 4 & 60 & 6 & 40 & 6 & 40 & 8 & 20 & $\mathbf{B}$ & 20 \\
\hline 8 & 70 & 9 & 60 & 9 & 60 & 12 & 30 & 12 & 30 \\
\hline 11. & 100 & 14 & 70 & 14 & 70 & 18 & 30 & 18 & 30 \\
\hline 18 & 120 & 20 & 100 & 20 & 100 & 26 & 40 & 26 & 40 \\
\hline 25 & 130 & 27 & 110 & 28 & 100 & 33 & 50 & 33 & 50 \\
\hline 36 & 170 & 39 & 140 & 40 & 130 & 48 & 50 & 47 & 60 \\
\hline 56 & 200 & 61 & 150 & 61 & 150 & 68 & 80 & 70 & 60 \\
\hline 81 & 250 & 88 & 180 & 86 & 200 & 96 & 100 & 99 & 70 \\
\hline 107 & 250 & 111 & 210 & 112 & 200 & 122 & 100 & 124 & 80 \\
\hline
\end{tabular}


Apêndice 3 - Dados experimentais das isotermas de adsorça de sulfato das amostras do latossolo vermelho-escuro, nos diferentes tratamentos - medias de duas repetiçช̃es.

\begin{tabular}{|c|c|c|c|c|c|c|c|c|c|}
\hline \multicolumn{2}{|c|}{$T$} & \multicolumn{2}{|c|}{$P$} & \multicolumn{2}{|c|}{ PAV } & \multicolumn{2}{|c|}{$\mathrm{PCa}$} & \multicolumn{2}{|c|}{ PCaAv } \\
\hline sol! & ads? & sol. & ads. & sol. & ads & sol. & ads. & sol. & ads. \\
\hline & & & & 40 & $-60 \mathrm{~cm}$ & & & & \\
\hline 3 & 70 & 5 & 50 & 6 & 40 & 8 & 20 & 8 & 20 \\
\hline 4 & 110 & 8 & 70 & 9 & 60 & 12 & 30 & 11 & 40 \\
\hline 7 & 140 & 13 & 80 & 13 & 80 & 16 & 50 & 15 & 60 \\
\hline 12 & 180 & 18 & 120 & 20 & 100 & 25 & 50 & 23 & 70 \\
\hline 17 & 210 & 24 & 140 & 27 & 110 & 29 & 90 & 29 & 90 \\
\hline 29 & 240 & 37 & 160 & 40 & 130 & $(35)$ & (180) & (35) & (180) \\
\hline (53) & $(230)$ & 58 & 180 & 60 & 160 & 60 & 100 & 60 & 100 \\
\hline 79 & 270 & 86 & 200 & 88 & 180 & $(74)$ & $(320)$ & $(74)$ & (320) \\
\hline 104 & 280 & 112 & 200 & 112 & 200 & 114 & 180 & 115 & 170 \\
\hline
\end{tabular}

$\mathrm{So}^{2-}=$ concentraçăo de sulfato na soluçăo de equilibrio. $\mathrm{SO}_{4}{ }^{2-}$ ads. = concentraçăo de sulfato adsorvido ao solo.

$($ ) = Dados năo utilizados no cálculo da curva de regressão, por serem muito discrepantes dos demais. 